\title{
Preparation of Imidazolidin-4-ones and Their Evaluation as Hydrolytically Cleavable Precursors for the Slow Release of Bioactive Volatile Carbonyl Derivatives
}

\author{
Alain Trachsel, ${ }^{[a]}$ Barbara Buchs, ${ }^{[a]}$ Guillaume Godin, ${ }^{[a]}$ Aurélien Crochet,,${ }^{[b]}$ \\ Katharina M. Fromm, ${ }^{*[b]}$ and Andreas Herrmann*[a]
}

Keywords: Fragrances / Nitrogen heterocycles / Aldehydes / Ketones / Hydrolysis

Imidazolidin-4-ones are suitable in practical applications as hydrolytically cleavable precursors for the controlled release of fragrant aldehydes and ketones. The corresponding profragrances were prepared by treating aliphatic carbonyl compounds with commercially available amino acid amines in the presence of a base to yield mixtures of diastereomers. The two diastereomers isolated from the reaction of glycinamide hydrochloride with (-)-menthone were separated by column chromatography. The absolute stereochemistry of the isomers was determined by NMR spectroscopy and confirmed by X-ray single crystal structure analysis. Under acidic conditions and in protic solvents, the two diastereomers slowly isomerized without releasing the ketone.
The hydrolysis of the precursors was investigated by solvent extraction from buffered aqueous solutions and a cationic surfactant emulsion, as well as by dynamic headspace analysis after deposition onto a cotton surface. Generally, ketones were shown to be more readily released than aldehydes. Increasing the size of the substituents at C-5 decreased the rate of hydrolysis in solution and on the cotton surface. Glycinamide-based imidazolidin-4-ones were more efficient than the corresponding oxazolidin-4-ones or oxazolidines. Neither the release rates in solution, nor the hydrophobicity of the precursor structure (which influences deposition), nor the combination of these two parameters allowed easily predicting the performance of the delivery systems in application.

\section{Introduction}

Bioactive volatile compounds, so-called semiochemicals or signalling compounds, serve in nature as a means for the communication between species. As a consequence of their pleasant smell or taste to humans, some of these compounds are also used as flavors or fragrances in our everyday life. ${ }^{[1]}$ To be perceived, these compounds must evaporate from a surface and move through the air to reach their target. As a result, they have high volatilities (vapor pressures) and, thus, a limited duration of smell. To increase the duration in the perception of fragrances in functional perfumery, so-called profragrances or properfumes have been developed as nonvolatile precursors, which slowly release volatile compounds by covalent bond cleavage under mild environmental conditions. ${ }^{[2,3]}$

Water is presumably the most commonly used solvent for applications in functional perfumery, and therefore, hydrolytically labile precursors are particularly interesting as profragrances. ${ }^{[2]}$ The successful development of hydrolytically

[a] Firmenich SA, Division Recherche et Développement, Route des Jeunes 1, B. P. 239, 1211 Genève 8, Switzerland E-mail: andreas.herrmann@firmenich.com

[b] Université de Fribourg, Département de Chimie, Chemin du Musée 9, 1700 Fribourg, Switzerland E-mail: katharina.fromm@unifr.ch labile profragrances depends on the behavior of the precursors at different $\mathrm{pH}$ levels and, in particular, in the presence of surfactants. However, fragrance delivery systems usually must be stored in an aqueous environment. An ideal compromise between high precursor stability (during product storage) and efficient hydrolysis to release the volatile (in use) is often difficult to achieve. ${ }^{[2]}$

1,3-Heterocycles have been repeatedly considered as hydrolytically cleavable precursors for the release of fragrant aldehydes or ketones (see Figure 1). ${ }^{[2]}$ Although successfully applied under certain conditions, cyclic acetals or ketals ${ }^{[4]}$ are generally too stable to efficiently release the correspond-

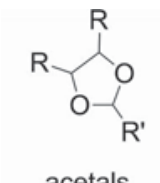

$$
\underbrace{\mathrm{O}-\overbrace{\mathrm{N}^{-}}^{\mathrm{O}}}_{\mathrm{R}^{\prime}}
$$

oxazolidinones

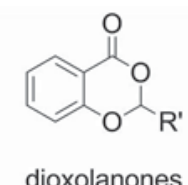

$$
\underbrace{R}_{R^{\prime}}
$$

imidazolidines (aminals)<smiles>[R]C1OC([R])N([R])C1[R]</smiles><smiles></smiles>

imidazolidinones
Figure 1. 1,3-Heterocyclic structures investigated for the controlled release of bioactive volatiles. 
ing aldehydes or ketones under mild reaction conditions at neutral $\mathrm{pH}$. Efforts have been made to prepare less stable heterocycles and, thus, to increase the rates of hydrolysis by introducing various substituents onto the heterocycle. The rate of aldehyde release from dicarboxyldioxolanes, for example, was expected to be influenced by varying the bulkiness of the carboxylate ester groups, ${ }^{[5]}$ and other structures obtained by modifying the substitution on the heterocycle include dioxolanones ${ }^{[6]}$ or aldoxanes. ${ }^{[7]}$

In addition, less stable heterocycles such as oxazolidines ${ }^{[8]}$ or imidazolidines (aminals $)^{[9,10]}$ have been explored to control the release of fragrances. While oxazolidines have been reported to rapidly hydrolyze in aqueous media under acidic or neutral conditions, ${ }^{[11]}$ aminals form an equilibrium with the corresponding diamine and aldehyde (see Scheme 1). ${ }^{[12]}$ Aminals, presumably the least stable compounds in the series, have been explored as "classical" profragrances to be hydrolyzed ${ }^{[9]}$ or, by profiting from the reversibility of the system, as dynamic mixtures obtained by reacting a diamine with several aldehydes or ketones. ${ }^{[10]}$ In search of easily accessible and biocompatible precursor systems, we investigated the use of amino acid amides in the formation of imidazolidin-4-ones (imidazolidinones).

$$
\text { 等 }
$$

Scheme 1. Controlled release of volatile aldehydes by reversible formation and hydrolysis of aminals (top) and imidazolidin-4-ones (bottom).

Aldehydes or ketones react with amino acid amides and (di)peptides to form imidazolidinones, ${ }^{[13-37]}$ which have previously been investigated as prodrugs by several research groups. ${ }^{[25-29]}$ In particular, the formation of hetacillin from 6-(D- $\alpha$-aminophenylacetamido)penicillanic acid (ampicillin) with acetone ${ }^{[29]}$ and the preparation of the imidazolidinone derivatives of primaquine as peptidomimetic antimalarial $\operatorname{drugs}^{[25]}$ have been studied in some detail. Despite the reversibility of the reaction, ${ }^{[21,29]}$ imidazolidinones have been described to be relatively stable at neutral $\mathrm{pH}$ and to hydrolyze under acidic conditions. ${ }^{[25-31]}$ Hydrolysis in a buffered solution was found to be of pseudo-first order (with half-life times of several hours or days at physiological $\mathrm{pH}$ ) and neither acid- nor base-catalyzed. Both the substituents at the C-2 and C-5 imidazolidin-4-one moiety influenced the reactivity. ${ }^{[21,25,27]}$

From these findings and in view of our recent studies using dynamic mixtures obtained by the reversible formation and hydrolysis of aminals with fragrant aldehydes and ketones, ${ }^{[10]}$ we investigated the potential of imidazolidinones as precursors in the controlled release of fragrant aldehydes and ketones by optimizing their synthesis and purification, by studying their hydrolysis in aqueous media, and by testing their performance in different applications of functional perfumery in more detail. ${ }^{[38]}$ In this work, we focused our interest on the use of aliphatic aldehydes and ketones.

\section{Results and Discussion}

\section{Synthesis and Isomerization of Imidazolidinones}

Imidazolidinones 1-9 (see Figure 2) were prepared by treating commercially available 2-aminoacetamide (hydrochloride) derivatives with typical fragrant aldehydes or ketones. Profragrances 1a-1d were obtained starting from ( \pm )-3-phenylbutanal (Trifernal ${ }^{\circledR}$ ) in ethanol with solid $\mathrm{K}_{2} \mathrm{CO}_{3}$ to trap the water formed during the reaction. As glycinamide, L-alaninamide, and L-phenylalaninamide were available as hydrochlorides, 1 equiv. of triethylamine (TEA) was added to neutralize the hydrochloride salt, whereas Dprolinamide $[(S)$-pyrrolidine-2-carboxamide $]$ was not treated with TEA. Compounds 1a-1d were obtained in reasonable to good yields by simply heating at $60^{\circ} \mathrm{C}$ for $1 \mathrm{~d}$. Although this method worked well for the preparation of a series of Trifernal ${ }^{\circledR}$ derivatives, it turned out not to be generally applicable to the preparation of imidazolidinones from other carbonyl compounds. To extend our delivery systems to the release of ketones, we investigated the formation and purification of imidazolidinones in more detail. A series of methods allowing the preparation of imidazolid-
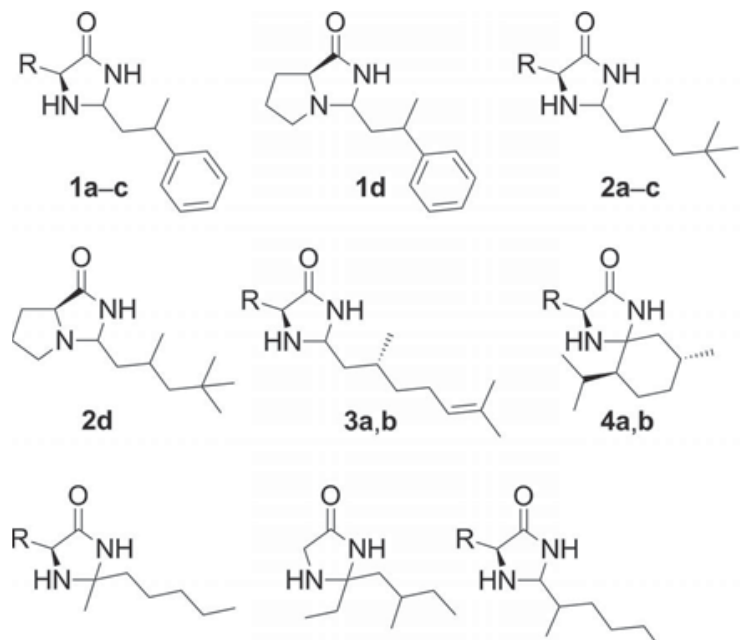

$5 a, c$

$6 a$

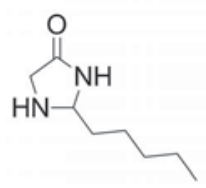

$8 \mathbf{a}$
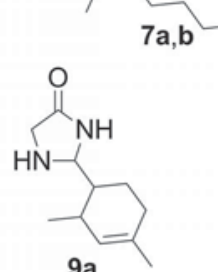

$$
\text { a: } \mathrm{R}=\mathrm{H} \quad \text { b: } \mathrm{R}=\mathrm{CH}_{3} \quad \text { c: } \mathrm{R}=\mathrm{CH}_{2} \mathrm{Ph}
$$

Figure 2. Structures of imidazolidin-4-ones 1-9 prepared and investigated as fragrance delivery systems. 
inones from amino acid amides with aldehydes or ketones have been described. ${ }^{[13-26,30-37]}$

According to the literature, imidazolidinones from aliphatic aldehydes or ketones were prepared in polar solvents such as dimethylformamide, ${ }^{[14]}$ methanol, or ethanol ${ }^{[18-22]}$ and, in particular, if the hydrochloride of the amino acid amide was used, they were prepared in the presence of a base (TEA or $\mathrm{NaOH}) .{ }^{[23-26]}$ Pure products were obtained by acidic workup and column chromatography ${ }^{[14,19-21,25,26]}$ or by extraction and recrystallization. ${ }^{[24]}$ Alternatively, reactions were carried out in methanol or isopropanol by using zeolites, para-toluenesulfonic acid, acetic acid, or trifluoroacetic acid (TFA) as catalysts. ${ }^{[15-17]}$ Imidazolidinones of sterically demanding pivalaldehyde were prepared under acidic conditions (in the presence of TFA) in dichloromethane or toluene ${ }^{[13,39]}$ followed by basic workup and crystallization or chromatography to afford pure imidazolidinones in moderate to good yields. Other methods describe the reaction in benzene or toluene with the azeotropic removal of water, typically in the presence of an acidic catalyst. ${ }^{[18,30,33,34]} \mathrm{A}$ series of imidazolidinones of aromatic aldehydes or aliphatic ketones was also obtained without the addition of solvent. ${ }^{[31,32]}$

To have a universally applicable method for the synthesis of imidazolidinones, we optimized the preparation of imidazolidinones 3a, 4a, 5a, and $\mathbf{6 a}$ (see Figure 2) by treating glycinamide hydrochloride with $(R)$-3,7-dimethyl-6-octenal $[(R)$-citronellal], (2S,5R)-2-isopropyl-5-methylcyclohexanone [(-)-menthone], 2-heptanone, and ( \pm )-5-methyl-3-heptanone, respectively, on the basis of some of the above-mentioned literature procedures. ${ }^{[13,20,24,25,39]}$

Treatment of glycinamide hydrochloride with $(R)$-citronellal in dichloromethane or toluene in the presence of TFA $^{[13,39]}$ entirely consumed the aldehyde, but did not afford target compound 3a. 2-Heptanone, (士)-5-methyl-3heptanone, and (-)-menthone did not react under these conditions, and the unreacted ketones were the only products isolated. The reaction of glycinamide hydrochloride in ethanol, in the absence of TEA, ${ }^{[20]}$ afforded imidazolidinone $\mathbf{3} \mathbf{a}$ in low purity, but no reaction occurred in the case of the ketones.

In the presence of TEA, ${ }^{[24,25]}$ imidazolidinones $4 \mathbf{a}-\mathbf{6 a}$ were finally isolated in reasonable purity after bulb-to-bulb distillation (to remove the remaining unreacted ketones), and pure $\mathbf{3 a}$ and $\mathbf{3 b}$ were obtained after plug filtration through silica gel using ethyl acetate as the eluent. Imidazolidinones of ( \pm )-3,5,5-trimethylhexanal (i.e., 2a-d), ( \pm )2-methylundecanal (i.e., 7a and 7b), hexanal (i.e., 8a), and (士)-2,4-dimethyl-3-cyclohexene-1-carbaldehyde (Triplal ${ }^{\circledR}$, i.e., 9a) were prepared accordingly. With the exception of $\mathbf{5 a}$ and $\mathbf{8 a}$, the imidazolidinones were isolated as mixtures of diastereomers.

Column chromatography of $\mathbf{4 a}$ allowed separating the two diastereomers $(5 R, 6 S, 9 R)-\mathbf{4 a}$ (eluting first) and $(5 S, 6 S, 9 R)-4 a$ (eluting second), both of which were fully characterized. The absolute stereochemistry of the two isomers was determined by $1 \mathrm{D}$ and 2D homonuclear and heteronuclear ${ }^{1} \mathrm{H}$ and ${ }^{13} \mathrm{C}$ NMR experiments in $\mathrm{CDCl}_{3}$ and confirmed by X-ray single crystal structure analysis. Some single crystal structures of different imidazolidin-4-one derivatives have already been reported in the literature. ${ }^{[16-19,36]}$ Compound $(5 S, 6 S, 9 R)-4 a$ (200 mg, isolated from a pure chromatography fraction) was dissolved in a mixture of $0.5 \mathrm{~mL}$ of ethyl acetate and $2.5 \mathrm{~mL}$ of heptane and left to crystallize overnight. X-ray crystal structure analysis showed the presence of multiple twinned crystals, which were not suitable for single crystal X-ray diffraction. Recrystallization from pure heptane finally afforded colorless single crystals, allowing for precise X-ray crystal structure determination (see Figures 3 and 4).

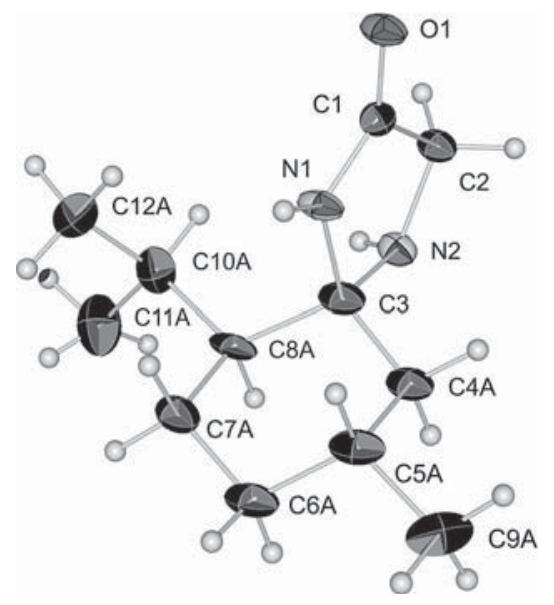

Figure 3. View of the molecular structure of $(5 S, 6 S, 9 R)-4 a(30 \%$ probability).

Compound $(5 S, 6 S, 9 R)-4 a$ crystallized in the trigonal space group $P 3_{1} 21$ (No. 152) in two crystallographic positions with an occupancy of $70 \%$ (Figure 3, Position A) and $30 \%$ (see Supporting Information, Figure S1, Position B). The two positions differ by the angle between the imidazole and the cyclohexane moieties [N-1-C-3-C-4 of $111.8(4)^{\circ}$ for part $\mathrm{A}$ and $102.0(6)^{\circ}$ for part $\mathrm{B}$. The two molecules have the same shape in which the cyclohexane ring takes a chair conformation with a torsion angle for C-3-C-4A-C-5A-C$6 \mathrm{~A}$ of $58.2(8)^{\circ}\left[48(2)^{\circ}\right.$ for C-3-C-4B-C-5B-C-6B]. The imidazole ring has a torsion angle of $17.4(4)^{\circ}$ (for C-2-N2-C-3-N-1). The two nitrogen atoms N-1 and N-2 [C-1-N$1-\mathrm{H}-1,124(3)^{\circ}$ and $\left.\mathrm{C}-2-\mathrm{N}-2-\mathrm{H}-2,109(2)^{\circ}\right]$ form intermolecular bonds with the neighboring molecules (see Figure 4). Indeed, $\mathrm{H}-1$ forms a hydrogen bond with $\mathrm{O}-1$ of the next molecule $[\mathrm{H}-1 \cdots \mathrm{O}-1,2.10(6) \AA$ and $\mathrm{N}-1-\mathrm{H}-1 \cdots \mathrm{O}-1$, 172(4) ${ }^{\circ}$, see Supporting Information, Figure S3) to yield an eight-membered hydrogen-bonded ring system with $\mathrm{H}-1-\mathrm{N}-$ 1-C-1-O-1 and the symmetry equivalents of a neighboring molecule, whereas $\mathrm{H}-2$ forms a short contact with O-1 of yet another neighbor, with the angle of $\mathrm{N}-2-\mathrm{H}-2 \cdots \mathrm{O}-1$ being $156(3)^{\circ}[\mathrm{H}-2 \cdots \mathrm{O}-1,2.28(5) \AA]$.

When left on silica gel, compound $(5 S, 6 S, 9 R)-4 a$ partially equilibrated to the $(5 R, 6 S, 9 R)-4 \mathbf{a}$ isomer, presumably according to the mechanism illustrated in Scheme 2.

The isomerization of $(5 R, 6 S, 9 R)$ - and $(5 S, 6 S, 9 R)-4 \mathbf{a}$ under acidic conditions was investigated in more detail by mixing small amounts of the pure diastereomers with silica 


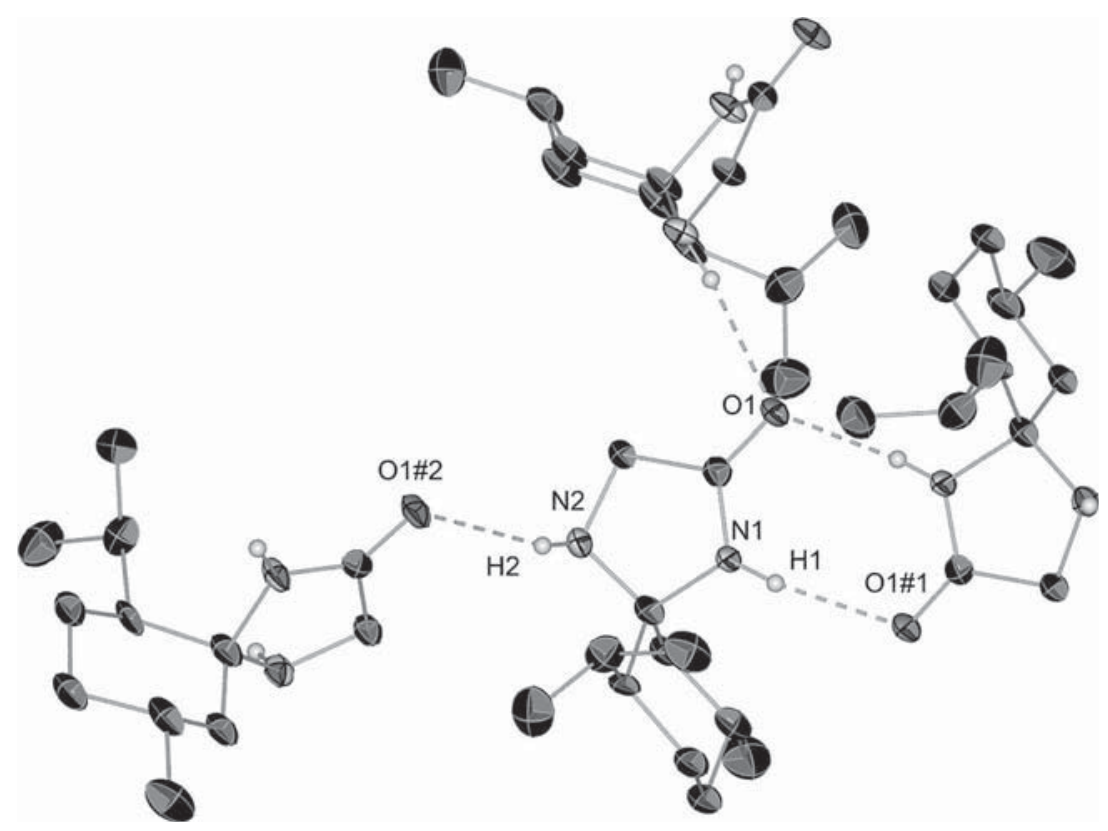

Figure 4 . View of the crystal packing of $(5 S, 6 S, 9 R)-\mathbf{4 a}(30 \%$ probability). Some hydrogen atoms are omitted for clarity. Hydrogen bonds are represented by dashed lines.

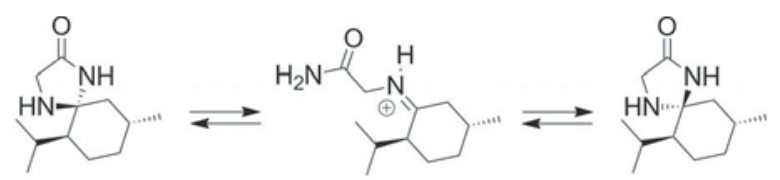

$(5 R, 6 S, 9 R)-4 a$
$(5 S, 6 S, 9 R)-4 a$

Scheme 2. Hypothetical mechanism for the isomerization of imidazolidinones $(5 R, 6 S, 9 R)$ - and $(5 S, 6 S, 9 R)-\mathbf{4 a}$ under acidic conditions.

gel or TFA (at a final concentration of $0.1 \%$ ) in ethyl acetate or chloroform. The product mixtures were stirred overnight (approximately $15 \mathrm{~h}$ ) and analyzed by NMR spectroscopy. Table 1 illustrates the product distributions obtained under the different conditions. Isomerization was relatively slow, as stable equilibrium conditions [equal to constant amounts of $(5 R, 6 S, 9 R)$ - and $(5 S, 6 S, 9 R)-4 a]$ were not reached after approximately $15 \mathrm{~h}$. Isomerization only occurred in protic solvents or in the presence of a proton source such as acidic silica gel or TFA.

Leaving a solution of the pure isomers $(5 R, 6 S, 9 R)-4 \mathbf{a}$ or $(5 S, 6 S, 9 R)-\mathbf{4 a}$ in methanol for several days showed that an equilibrium between the two isomers was in fact reached, resulting in a final composition of $(5 R, 6 S, 9 R)-\mathbf{4 a}$ / $(5 S, 6 S, 9 R)-4 \mathbf{a}$ of approximately $2: 3$, independent of the

structure of the starting isomer as shown by ${ }^{13} \mathrm{C} \mathrm{NMR}$ spectroscopic data recorded at different time intervals (see Figure 5). The formation of (-)-menthone was not observed under these conditions. Solutions of the isomer $(5 S, 6 S, 9 R)$ 4a in $\mathrm{CDCl}_{3}$ or $\mathrm{C}_{6} \mathrm{D}_{6}$, for example, did not isomerize even after standing for $400 \mathrm{~h}$.

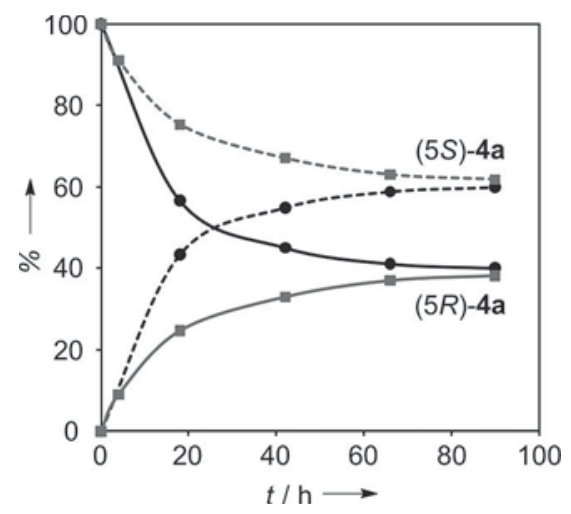

Figure 5. Amount of imidazolidinones $(5 R, 6 S, 9 R)-4 a$ (solid lines) and $(5 S, 6 S, 9 R)-\mathbf{4 a}$ (dotted lines) during equilibration in $\mathrm{CD}_{3} \mathrm{OD}$ as determined by ${ }^{13} \mathrm{C}$ NMR spectroscopy, starting from pure $(5 R, 6 S, 9 R)-\mathbf{4 a}(\bullet)$ or pure $(5 S, 6 S, 9 R)-\mathbf{4 a}(\mathbf{\square})$. For numerical data, see Exp. Section.

Table 1. Composition of ethyl acetate and chloroform solutions obtained after $15 \mathrm{~h}$ for the isomerization of imidazolidinones $(5 R, 6 S, 9 R)$ 4a and $(5 S, 6 S, 9 R)-\mathbf{4 a}$ in the presence of $\mathrm{SiO}_{2}$ or TFA.

\begin{tabular}{|c|c|c|c|c|c|c|c|c|}
\hline \multirow[t]{2}{*}{$\begin{array}{l}\text { Final composition } \\
{[\%]}\end{array}$} & \multicolumn{2}{|c|}{$\begin{array}{c}\text { Starting isomer } \\
{\left[\mathrm{SiO}_{2}, \text { ethyl acetate }\right]}\end{array}$} & \multicolumn{2}{|c|}{$\begin{array}{c}\text { Starting isomer } \\
\text { [TFA, ethyl acetate] }\end{array}$} & \multicolumn{2}{|c|}{$\begin{array}{c}\text { Starting isomer } \\
{\left[\mathrm{SiO}_{2}, \text { chloroform }\right]}\end{array}$} & \multicolumn{2}{|c|}{$\begin{array}{c}\text { Starting isomer } \\
\text { [TFA, chloroform] }\end{array}$} \\
\hline & $(5 R)-\mathbf{4 a}$ & $(5 S)-\mathbf{4 a}$ & $(5 R)-\mathbf{4 a}$ & $(5 S)-\mathbf{4 a}$ & $(5 R)-\mathbf{4 a}$ & $(5 S)-\mathbf{4 a}$ & $(5 R)-\mathbf{4 a}$ & $(5 S)-\mathbf{4 a}$ \\
\hline$(5 R, 6 S, 9 R)-\mathbf{4 a}$ & 80 & 9 & 80 & 6 & 89 & 28 & 79 & 8 \\
\hline$(5 S, 6 S, 9 R)-\mathbf{4 a}$ & 20 & 91 & 20 & 94 & 11 & 72 & 21 & 92 \\
\hline
\end{tabular}




\section{Synthesis of Structurally Related Oxazolidinones and Oxazolidines}

To compare the performance of fragrance release from the imidazolidinones with that of other hydrolytically cleavable 1,3-heterocycles, we prepared oxazolidin-4-one $\mathbf{1 0}$ and oxazolidine 11 (see Figure 6) as additional reference compounds, both of which were expected to release 3,5,5-trimethylhexanal.
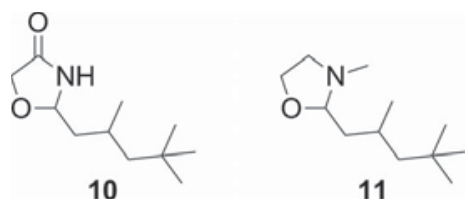

Figure 6. Structures of oxazolidin-4-one $\mathbf{1 0}$ and oxazolidine 11, serving as reference compounds with a different 1,3-heterocyclic moiety.

A few literature methods describe the synthesis of oxazolidin-4-ones by reaction of an $\alpha$-hydroxyamide with the corresponding carbonyl compound in toluene or benzene and in the presence of para-toluenesulfonic acid. ${ }^{[40,41]} \mathrm{Al}$ though reasonable yields have been reported in the literature, the reaction of 2-hydroxyacetamide with different aldehydes under these conditions gave only small amounts $(5-10 \%)$ of the desired oxazolidin-4-ones. We finally prepared oxazolidin-4-one $\mathbf{1 0}$ by reaction in tetrahydrofuran (THF) in the presence of boron trifluoride etherate. ${ }^{[41]}$ Again, the desired product was obtained in only modest yield $(11 \%)$.

Nevertheless, with sufficient amounts of product in hand to serve as a reference for the release studies, we did not further optimize the preparation of the oxazolidin-4-ones. Oxazolidine 11 was prepared without any difficulty by reaction of 2-(methylamino)ethanol with the corresponding carbonyl compound under para-toluenesulfonic acid-catalyzed cyclization along with the azeotropic removal of water.

\section{Hydrolysis of Imidazolidinones in Aqueous Media}

The hydrolysis of imidazolidinones was investigated in buffered aqueous solutions at $\mathrm{pH}=4.6$ (potassium hydrogen phthalate) and 7.3 (sodium/potassium phosphate), thus covering a slightly acidic or neutral $\mathrm{pH}$ range, typically found in various perfumed consumer articles. For solubility reasons, the buffers were prepared in a mixture of water/ acetonitrile (4:1). Furthermore, because most formulations of applied perfumery contain surfactants, we also analyzed the hydrolysis of the imidazolidinones in an emulsion of a cationic surfactant in water at $\mathrm{pH}=4.4$. As a surfactant helps to solubilize hydrophobic compounds in an aqueous environment, the emulsion was prepared in pure water.

For our studies, we chose a quaternized triethanolamine ester of fatty acids (TEA-esterquat) as the cationic surfactant, which is commonly used as a rinse-added fabric softening agent. ${ }^{[42]}$ Concentrated fabric softener formulations typically consist of approximately $15 \%(w / w)$ of the esterquat (mixture of mono-, di-, and triesters) in water, up to $1 \%$ perfume, small amounts of $\mathrm{CaCl}_{2}$, and, optionally, a dye. In use, this concentrated formulation is diluted by a factor of about 300-400 before coming into contact with the fabric, onto which the surfactant, the perfume, and the profragrances are then deposited. ${ }^{[43]}$ Aggregation of the surfactant to form micelles enables the precursor (as well as the carbonyl compounds released from them) to partition between the inside and outside of the surfactant aggregates. The hydrophilicity or hydrophobicity of the different compounds, expressed by their logarithmic octanol/water partition coefficients $\left(\log P_{\mathrm{o} / \mathrm{w}}\right),{ }^{[44]}$ might influence the partition and could therefore have an influence on the hydrolysis of the compounds. Table S1 (see Supporting Information) summarizes the calculated $\log P_{\mathrm{o} / \mathrm{w}}$ of the precursors prepared as described above. ${ }^{[4]}$

Release measurements were carried out in duplicate in a glass flask by adding an ethanolic solutions of imidazolidinones 1-9 to either one of the buffer solutions or the cationic surfactant emulsion to give a final concentration of approximately $1.5 \times 10^{-4} \mathrm{~mol} \mathrm{~L}^{-1}$. The samples were shaken vigorously and left at room temperature $\left(21.7^{\circ} \mathrm{C} \pm 1.7^{\circ} \mathrm{C}\right)$ for two weeks. At different time intervals, an aliquot of the solutions or the emulsion was removed by pipette and extracted with heptane. The amount of volatiles released from the precursor was then determined by analyzing the heptane extract by gas chromatography (GC). Removing aliquots of the reaction medium at regular time intervals continuously decreased the total volume of the solution or emulsion in the closed flask and increased the headspace above it. We observed that the increasing headspace volume above the sample had almost no influence on the recovery of the volatiles by solvent extraction (see Supporting Information).

The efficiency of the extraction from the different media used in this work was verified with 3,5,5-trimethylhexanal as an example. Known quantities of the aldehyde (corresponding to $1,5,10,50$, and 100 mol- $\%$ of the total amount to be theoretically released from the precursors) were added to the buffer solutions and the cationic surfactant emulsion. The samples were then extracted with heptane after standing for $1 \mathrm{~h}$ and $240 \mathrm{~h}$ and analyzed by GC. Figure 7 summarizes the data obtained from the extraction of the cationic surfactant emulsion. Under the present conditions, one can see that the recovery of 3,5,5-trimethylhexanal is not quantitative, as both curves (corresponding to the extraction after $1 \mathrm{~h}$ and after $240 \mathrm{~h}$ ) are lying below the diagonal line of the graph, which would correspond to $100 \%$ extraction. Nevertheless, the linearity of the lines indicates that constant amounts of aldehyde were extracted within the concentration range investigated in the present work. The fact that higher amounts of 3,5,5-trimethylhexanal were extracted after $1 \mathrm{~h}$ than after $240 \mathrm{~h}$ suggests that the aldehyde was not stable under the given conditions. A controlled release of the compound from a profragrance might therefore have a beneficial stabilizing effect. In the case of the cationic surfactant emulsion, about $40 \%$ of the aldehyde was lost 
(Figure 7), however, its degradation in the water/acetonitrile buffer solutions was considerably less pronounced (see Supporting Information, Figure S5 and Table S2).

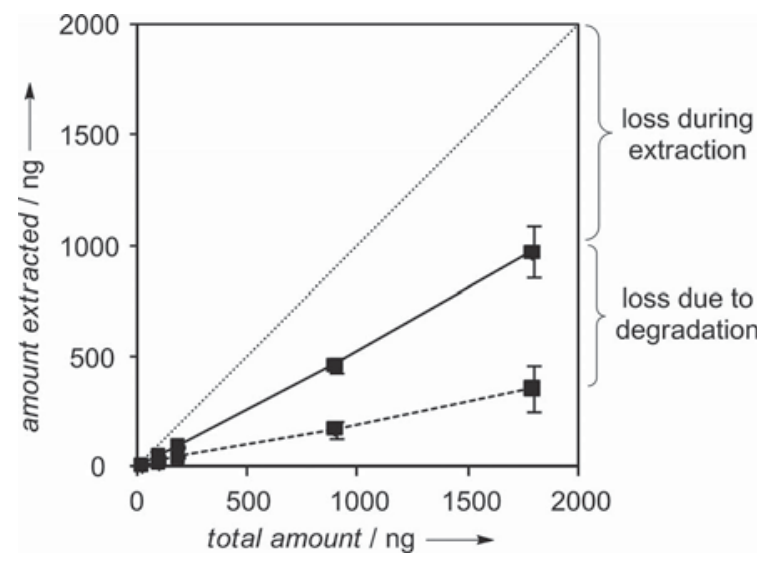

Figure 7. Efficiency of the heptane extraction of ( \pm )-3,5,5-trimethylhexanal (corresponding to $1,5,10,50$, and $100 \mathrm{~mol}-\%$ of the theoretical amount to be released from 2) from a cationic surfactant emulsion after standing for $1 \mathrm{~h}(-\mathbf{-}-)$ and $240 \mathrm{~h}(---\mathbf{- - -})$. For numerical data, see Supporting Information.

From these findings, we also determined the efficiency of extraction for the other fragrances at different concentrations with respect to the total amount to be released from the corresponding precursor. All compounds were only partially extracted after standing for $1 \mathrm{~h}$ (see Supporting Infor- mation, Table S3). Although similar quantities were typically recovered from the buffer solutions at $\mathrm{pH}=4.6$ and 7.3 , the extraction from the cationic surfactant emulsion was generally less efficient. The absolute values of aldehydes and ketones extracted from the different media were thus corrected according to this data. The incomplete recovery of the carbonyl compounds was expected to increase the standard deviations in the measurements. In particular, the extraction of only $7 \%$ of $( \pm)$-2-methylundecanal from the emulsion was expected to result in a larger error in the absolute value than would occur with the other compounds.

Figure 8 shows the amounts of carbonyl compounds (in mol- $\%$ ) released at different time intervals from imidazolidinones 1a-9a with respect to the total amount of precursor present at the beginning of the measurements (see Supporting Information, the corresponding numerical data are listed in Table S4). In all cases, the volatile carbonyl compounds were released from their precursors, although in some cases at only very low concentrations.

Although the amount of aldehydes recovered from the buffer solutions continuously increased with increasing reaction time, the aldehyde concentrations released from imidazolidinones $\mathbf{1}, \mathbf{2}, \mathbf{8}$, and 9 into the cationic surfactant emulsion reached a maximum after approximately $50 \mathrm{~h}$ and then rapidly dropped to values of almost zero. This strong decrease in concentrations was attributed to the degradation of the aldehydes as a result of their inherent instability in the surfactant emulsion.
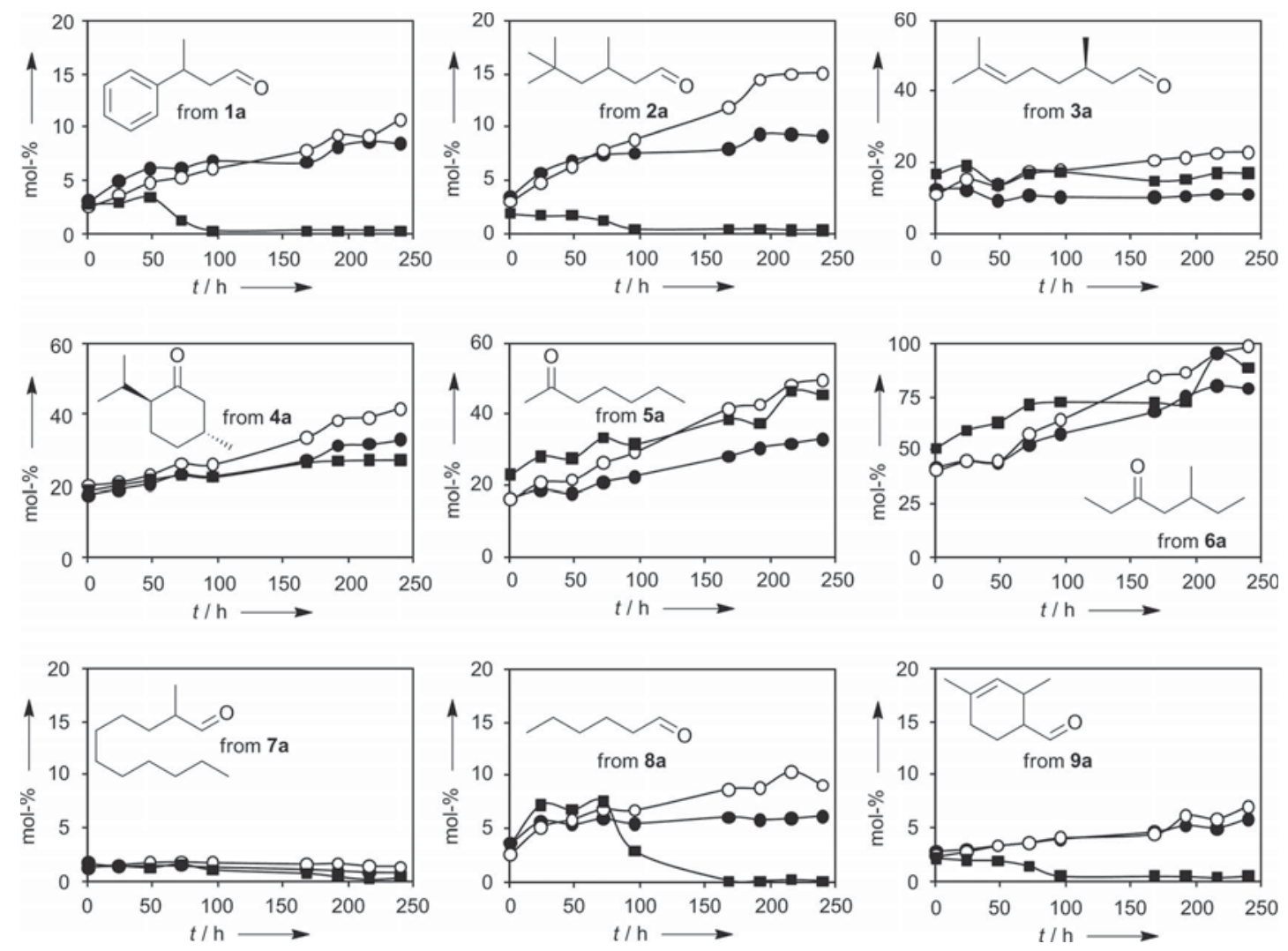

Figure 8. Comparison of the hydrolysis of imidazolidinones 1a-9a releasing different fragrant aldehydes and ketones in buffered solutions of water/acetonitrile $(4: 1)$ at $\mathrm{pH}=4.6(-\mathbf{O}-)$ and $7.3(-\mathrm{O}-)$ or in a diluted aqueous TEA-esterquat emulsion at $\mathrm{pH}=4.4(-\mathbf{\square}-)$. For numerical data, see Supporting Information. 
For imidazolidinones derived from the same amino acid amine, for example, glycinamide-based imidazolidinones 1a-9a, the ketones were generally more readily released than the aldehydes. At $\mathrm{pH}=7.3,15-40 \%$ of (-)-menthone, 2-heptanone, or 5-methyl-3-heptanone were released from 4a, 5a, and 6a, respectively, after $1 \mathrm{~h}$. After $240 \mathrm{~h}$, these values increased to $40 \%$ for $\mathbf{4 a}, 50 \%$ for $\mathbf{5 a}$, and even above $90 \%$ for $\mathbf{6 a}$. $(R)$-Citronellal derivative $\mathbf{3 a}$ was found to be the most efficient aldehyde precursor. Its release profile was relatively flat, forming $10-20 \%$ of the aldehyde over the entire period of the measurement, independent of the reaction medium. Hydrophobic imidazolidinone $7 \mathbf{a}$ released less than $2 \%$ of the corresponding 2-methylundecanal and, therefore, was quite stable under the conditions tested.

Keeping the same aldehyde structure yet varying the structure of the imidazolidinone showed that the substitution at C-5 strongly influenced the rate of hydrolysis for the corresponding heterocycle, which decreased with increasing size (or hydrophilicity) of the substituent. ${ }^{[25]}$ From the series of 3,5,5-trimethylhexanal-releasing precursors 2a-2d (see Figure 8 and Supporting Information, Figure S6), glycinamide-based imidazolidinone $\mathbf{2 a}$ hydrolyzed more readily than its alanine analogue $\mathbf{2 b}$ and phenylalanine derivative 2c. However, the structurally more rigid prolinamide analogue 2d released higher amounts of 3,5,5-trimethylhexanal than alanine derivative $\mathbf{2} \mathbf{b}$. The same trend was observed for Trifernal ${ }^{\circledR}$-releasing precursors 1a-1d, $(R)$-citronellal-releasing precursors $\mathbf{3} \mathbf{a}$ and $\mathbf{3 b}$, and (-)-menthone-releasing precursors $\mathbf{4 a}$ and $\mathbf{4 b}$ (see Figure 8 and Supporting Information, Figure S6).

The hydrolysis of imidazolidinones in the buffered solutions showed that, in general, slightly higher amounts of volatiles were released in the samples kept at $\mathrm{pH}=7.3 \mathrm{com}$ pared with those at $\mathrm{pH}=4.6$. The observation that higher amounts of aldehydes or ketones were usually extracted from the aqueous buffer solutions with respect to the cationic surfactant emulsion indicated that the presence of the surfactant had a stabilizing effect on the precursors by slowing down the rate of hydrolysis. This is also in line with previous observations made in a slightly different context. ${ }^{[46]}$

Despite the high standard deviations observed at the beginning of the experiment, oxazolidine 11 released the corresponding aldehyde almost quantitatively, both in the buffered solutions and in the cationic surfactant emulsion (see Supporting Information, Figure S8 and Table S6). Under the experimental conditions described, the oxazolidine hydrolyzes faster than the corresponding imidazolidinones.

The release kinetics recorded in the buffered solutions might help us to understand the general behavior of the precursors in an aqueous environment and to study the influence of the structural variations on the rate of hydrolysis. As a next step, we investigated the release of the volatile aldehydes and ketones from the corresponding imidazolidinones under more realistic application conditions by following their evaporation from a cotton surface.

\section{Release and Evaporation of Volatiles after Deposition on a Cotton Surface}

In practical applications, volatile compounds must be deposited and evaporated from a surface before being perceived as a fragrance. Typical surfaces, which are important for perfumery, are skin, hair, and fabric, especially cotton. Whereas the deposition of fragrances on skin is generally achieved by directly spraying ethanolic solutions onto the surface, the deposition onto other substrates, such as hair or cotton, is more complicated, as it has to occur during a washing (and rinsing) process.

Besides having a softening effect, cationic surfactants are known to be efficiently deposited onto cotton ${ }^{[42]}$ by transporting apolar compounds from an aqueous environment onto the surface of the fabric. ${ }^{[43]}$ Typically, the higher the $\log P_{\mathrm{o} / \mathrm{w}}$ of a given compound, the better it is expected to be deposited from an aqueous environment onto the fabric. To assess the performance of the profragrances under more realistic application conditions, we added a cotton sheet to the diluted TEA-esterquat emulsion described above containing the heterocyclic profragrance (or an equimolar amount of the corresponding reference fragrance to be released) and investigated the release of the volatile carbonyl compound by following its evaporation from dry cotton by employing dynamic headspace analysis. Dynamic headspace analysis ${ }^{[47]}$ has the advantage of directly quantifying the evaporated fragrance from the targeted surface without complicated sample preparation. The desired longevity of perception in the application is achieved if, after a certain time, higher headspace concentrations of the fragrances are measured above the samples with the profragrance than above the reference sample containing an equimolar amount of the corresponding unmodified fragrance. ${ }^{[10,48]}$

One of the imidazolidinone, oxazolidinone, or oxazolidine profragrances, prepared as described above, was added to a concentrated TEA-esterquat fabric softening formulation, which was then diluted with water. The diluted formulation corresponded to the emulsion that was used for the hydrolysis experiments described in the previous section. One small cotton square (approximately $12 \times 12 \mathrm{~cm}$ ) was added to the diluted surfactant emulsion for $5 \mathrm{~min}$ to allow the deposition of the cationic surfactant together with the profragrance (or the corresponding reference fragrance) onto the cotton surface. The cotton sheets were wrung out and air-dried for three days. For each measurement, one cotton square was placed inside a closed headspace-sampling cell and then exposed to a constant flow of air. The airflow was passed through an activated charcoal filter and a saturated sodium chloride solution to maintain constant humidity in the sampling cell. The fragrance evaporating from the cotton surface was trapped at constant time intervals onto a cartridge containing a polymeric adsorbent $\left(\right.$ Tenax $\left.^{\circledR}\right)$. After thermal desorption, the quantities of the volatiles trapped were determined by GC analysis. All analyses were compared with a reference sample composed of the unmodified fragrance, which was prepared and analyzed under the same conditions as the corresponding pro- 

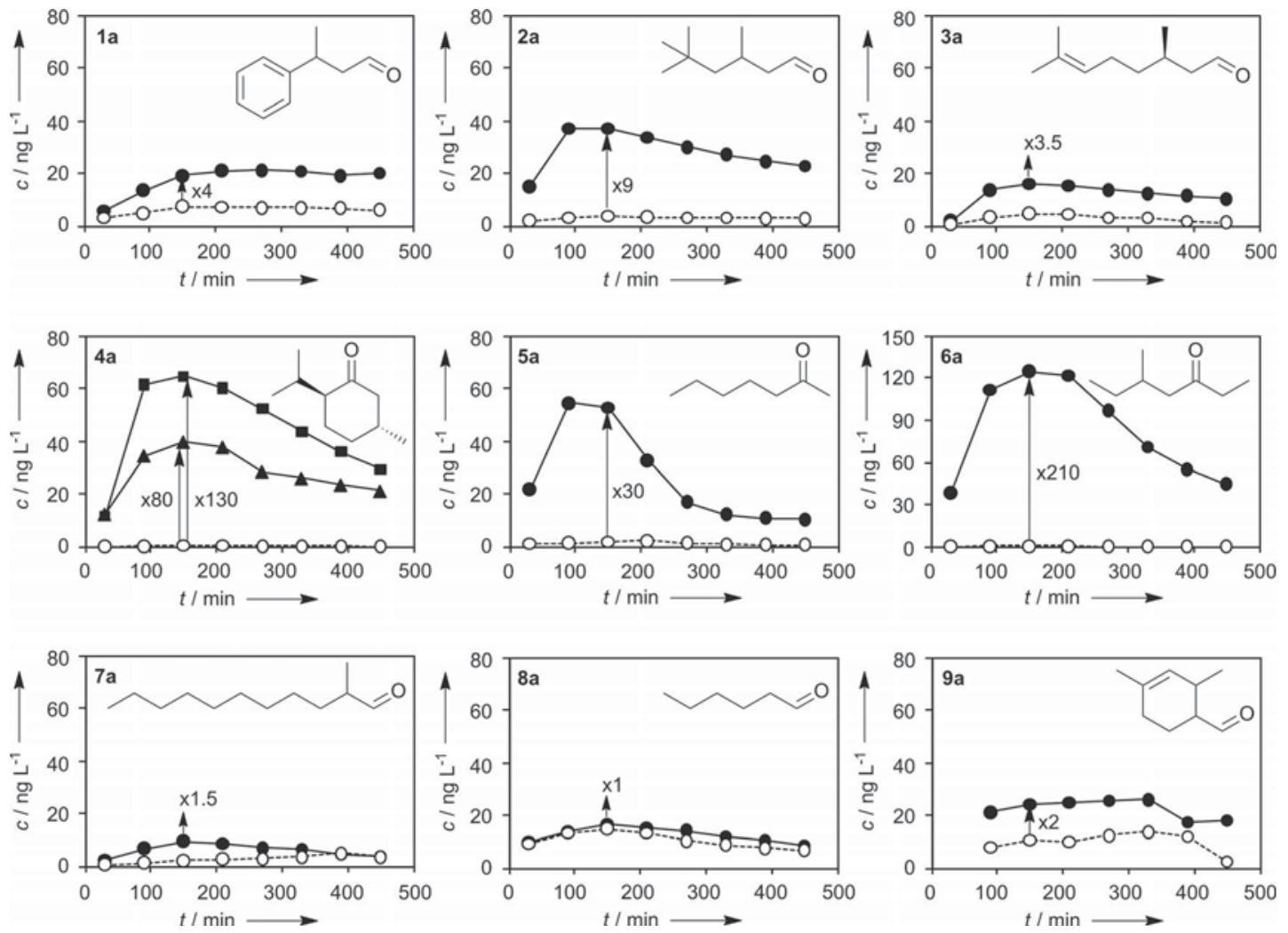

Figure 9. Dynamic headspace concentrations of different fragrant aldehydes and ketones (---○---) and the corresponding fragrant aldehydes and ketones released from glycinamide-derived imidazolidinones 1a-9a $(-\mathbf{-}-)$ measured on dry cotton after drying for three days. In the case of (-)-menthone derivative $\mathbf{4 a}$, both isomers were analyzed separately, $(5 R, 6 S, 9 R)-\mathbf{4 a}(-\boldsymbol{\Lambda}-)$ and $(5 S, 6 S, 9 R)-\mathbf{4 a}(-\mathbf{\square}-)$. For numerical data, see Supporting Information.

fragrance. Average values result from at least two measurements. ${ }^{[10,48]}$

Figure 9 shows the headspace concentrations of the aldehydes and ketones released from glycinamide derivatives 1a-9a compared to an equimolar amount of the corresponding unmodified reference (see Supporting Information, the corresponding numerical data are listed in Table S7).

In all cases, our data show that the carbonyl compounds were successfully released from the different imidazolidinones. As previously seen in the hydrolysis experiments, the release efficiency was influenced by the structure of the leaving carbonyl compounds. It is interesting to note that the headspace concentrations of the ketones evaporated from the reference samples were close to zero, whereas the headspace concentrations of the aldehydes varied between about 2 and $15 \mathrm{ng} \mathrm{L}^{-1}$. However, much higher headspace concentrations were measured for the ketones released from $\mathbf{4 a - 6 a}$ (approximately 10-125 $\mathrm{ng} \mathrm{L}^{-1}$ ) than for the aldehydes generated from 1a-3a and 7a-9a (approximately 2-50 $\mathrm{ng}^{-1}$ ). This difference is even more pronounced when comparing the ratios between the concentrations of the released compounds and the corresponding reference at a given time. After $150 \mathrm{~min}$ of sampling, approximately 210 times more 5-methyl-3-heptanone was found in the headspace above the sample treated with $\mathbf{6 a}$ than above the reference sample (see Figure 9). The presence of $\mathbf{5 a}$ increased the headspace of 2-heptanone by a factor of 30 with respect to the reference. 3,5,5-Trimethylhexanal was the most efficiently released aldehyde, with an increase in headspace concentration by a factor of about 8 . The release of 2-methylundecanal from $7 \mathbf{a}$ and hexanal from $\mathbf{8 a}$ resulted in almost the same headspace concentrations as those measured for the unmodified reference. The strong dependence on the structure of the leaving carbonyl compound could be illustrated by the release of (-)-menthone from $(5 R, 6 S, 9 R)$ - and $(5 S, 6 S, 9 R)-4 a$. The two isomers were measured separately and, under the present reaction conditions, the $(5 S)$-isomer released about 1.5 times more $(-)$-menthone than its $(5 R)$ analogue.

Absolute headspace concentrations measured by the present method show large variations, which presumably result from the lack of control of various parameters during the line drying of the cotton sheets. Nevertheless, relative values (obtained by comparison to the reference) were found to be quite reproducible. Typically, the headspace concentrations increased at the beginning of the measurement and reached a maximum before decreasing again. This effect was generally observed for different types of precursors and has been attributed to the equilibration of the headspace cells. ${ }^{[10,48]}$

Figure 10 shows the headspace concentrations of a given aldehyde or ketone released from imidazolidinones with different substituents at C-5. With respect to the glycinamide- 

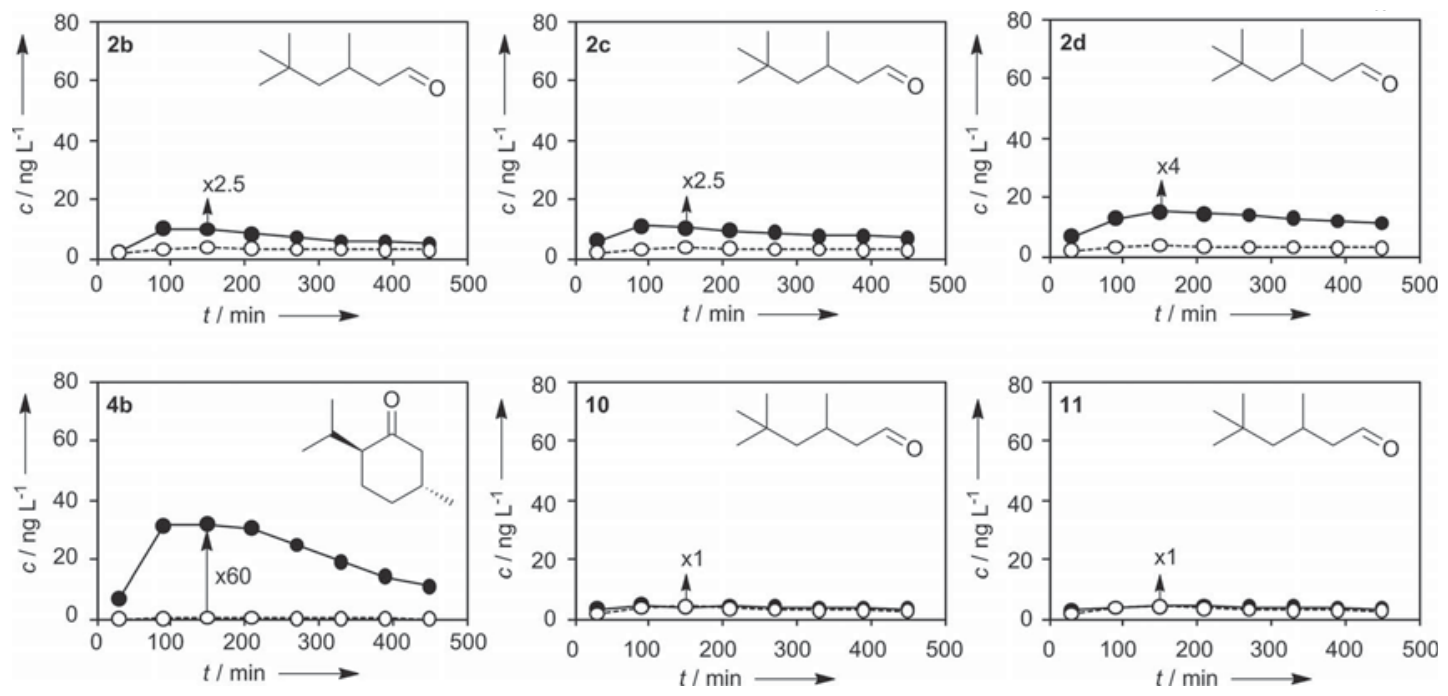

Figure 10. Dynamic headspace concentrations of different fragrant aldehydes and ketones (--- $\bigcirc---)$ and the corresponding fragrant aldehydes or ketones released from imidazolidinones $\mathbf{2 b}-\mathbf{2 d}, \mathbf{4} \mathbf{b}$; from oxazolidin-4-one 10; and from oxazolidine $\mathbf{1 1}(-\mathbf{0}-)$ measured on dry cotton after drying for three days. For numerical data, see Supporting Information.

based imidazolidinones (see Figure 9) and as seen in the hydrolysis experiments, the substitution at C-5 generally resulted in lower headspace concentrations of the corresponding carbonyl compounds released from the precursors.

Changing the substituent at C-5 from hydrogen (1a, 2a) to methyl (1b, 2b) and to benzyl (1c, 2c) decreased the hydrophilicity of the precursor (see Supporting Information, Table S1) and thus its water solubility. On the other hand, more hydrophobic molecules are expected to be more preferably deposited onto a cotton surface than more hydrophilic ones. ${ }^{[43,46]}$ Therefore, with an equally efficient hydrolysis reaction, one could expect the more hydrophobic precursor to give rise to the highest headspace concentrations in application. However, as stated above, hydrolysis efficiency works in the opposite direction with the more polar glycinamide-based imidazolidinones $\mathbf{1 a - 9 a}$ being more readily hydrolyzed than their C-5-substituted analogues. Overall, the efficiency of hydrolysis seems to be more important than the amount of precursor deposition.

Comparison of the data obtained for the release of the carbonyl compounds from imidazolidinones 1a-9a by hydrolysis (Figure 8) and headspace analysis (Figures 9 and 10) shows a correlation only within a homologous series of compounds with a different substituent at C-5 (e.g., imidazolidinones $\mathbf{2 a}-\mathbf{2 d}$ ) or with the ketone-releasing precursors 4a-6a. It is not possible to predict the efficiency of release of the different aldehydes in practical application from the hydrolysis data. For example, precursor 7a was relatively stable in a solution releasing less than 2 mol- $\%$ of the aldehyde after two weeks. Nevertheless, dynamic headspace analysis on cotton revealed a slight slow-release effect, when compared with the free aldehyde as the reference (see Figure 9). This effect might be due to a favorable deposition of the precursor as a result of its high $\log P_{\mathrm{o} / \mathrm{w}}$. On the other hand, oxazolidine $\mathbf{1 1}$ did not give rise to higher headspace concentrations of 3,5,5-trimethylhexanal on the dry cotton with respect to the reference sample, despite its almost quantitative hydrolysis in solution (see Figure 10). In this case, the hydrolysis in solution is probably so fast ${ }^{[11]}$ that the compound behaves almost like the unmodified reference sample. Similarly, although not tested in solution, oxazolidin-4-one 10 did not efficiently release 3,5,5-trimethylhexanal on the cotton and, thus, was not a suitable precursor for this type of application. Imidazolidinones were more efficient precursors for the targeted application than the corresponding oxazolidinones or oxazolidines.

\section{Conclusions}

The development of hydrolytically cleavable precursors for the controlled release of fragrances is particularly challenging, as these compounds are often stored in aqueous media and, thus, in the presence of the release trigger. Finding the ideal compromise between precursor stability and release efficiency is typically not easily achieved, especially as there are a considerable number of different physicochemical parameters to take into account. Subtle modifications of the precursor structure have an important influence on the interplay of these parameters and can, therefore, strongly impact the performance of these products in application.

Imidazolidin-4-ones are efficient precursors for the slow release of bioactive volatile compounds and prolong the longevity of fragrance evaporation in practical applications. Hydrolysis experiments carried out in buffered solutions of water/acetonitrile (4:1) at different $\mathrm{pH}$ levels or in a cationic surfactant containing aqueous emulsion showed that ketones were generally more readily released than aldehydes. Increasing the size of the substituents at C-5 increased the hydrophobicity of the precursors, but decreased the rate of hydrolysis in solution as well as on the target 
surface. Dynamic headspace analysis above a cotton surface showed that glycinamide-based imidazolidinones represented the ideal compromise between precursor stability and release efficiency for the applications tested.

Hydrolysis rates determined in solution might be useful for predicting the efficiency of a controlled release under physiological conditions for drug delivery, but these data are only partially relevant for evaluating the release of fragrances from different surfaces. Although the combination of release efficiency in solution and the amount of surface deposition were occasionally used to estimate the efficiency of fragrance-delivery systems, our data show that neither the release rates in solution, nor the hydrophobicity of the precursor structure, nor the combination of both was sufficient to predict the performance of the precursor-based fragrance-delivery systems in application. To control the release of volatiles, additional parameters such as equilibria resulting from the presence of surfactants, surface deposition, volatility of the released compounds, and evaporation rates will have to be considered to understand and improve fragrance delivery in future work.

Nevertheless, hydrolytically cleavable 1,3-heterocycles are important and efficient delivery systems within different areas of the life sciences, and our work will not only contribute to the future development of precursor-based release systems for fragrances, but also to the development of delivery systems for drugs, agrochemicals, and other bioactive compounds. More research efforts are required to better understand the interplay of the different parameters involved to predict and achieve an optimum performance of hydrolytically cleavable 1,3-heterocycles.

\section{Experimental Section}

General Comments: Commercially available reagents and solvents were used without further purification if not stated otherwise. Reactions were carried out in standard glassware under $\mathrm{N}_{2}$.

General Method for the Preparation of Imidazolidin-4-ones 1a-1d: A mixture of $( \pm)$-3-phenylbutanal $\left(\right.$ Trifernal $\left.^{\circledR}\right)$, amino acid amide hydrochloride, TEA, and $\mathrm{K}_{2} \mathrm{CO}_{3}$ in ethanol was heated to $60{ }^{\circ} \mathrm{C}$ for $24 \mathrm{~h}$. After cooling to room temperature, the solvent was removed, and the residue was dissolved in ether. The solvent was evaporated to yield the imidazolidin-4-one, usually as a mixture of diastereomers

( \pm )-2-(2-Phenylpropyl)imidazolidin-4-one (1a): This compound was prepared as described above from Trifernal ${ }^{\circledR}(0.67 \mathrm{~g}, 4.5 \mathrm{mmol})$, glycinamide hydrochloride $(0.50 \mathrm{~g}, 4.5 \mathrm{mmol})$, TEA $(0.46 \mathrm{~g}$, $4.5 \mathrm{mmol}), \mathrm{K}_{2} \mathrm{CO}_{3}$, and ethanol ( $\left.4 \mathrm{~mL}\right)$ to yield a highly viscous, yellow oil $(0.52 \mathrm{~g}, 57 \%)$ as a mixture of diastereomers still containing ethyl acetate. ${ }^{1} \mathrm{H}$ NMR $\left(400 \mathrm{MHz}, \mathrm{CDCl}_{3}\right): \delta=8.06$ (br. s, 1 $\mathrm{H}, \mathrm{NHC}=\mathrm{O}), 7.34-7.26(\mathrm{~m}, 2 \mathrm{H}, \mathrm{Ph}), 7.25-7.15(\mathrm{~m}, 4 \mathrm{H}, \mathrm{Ph}), 4.44$ $4.34[\mathrm{~m}, 1 \mathrm{H}, \mathrm{C}(2) \mathrm{H}], 3.45-3.28\left[\mathrm{~m}, 2 \mathrm{H}, \mathrm{C}(5) \mathrm{H}_{2}\right], 2.99-2.84$ (m, 1 $\left.\mathrm{H}, \mathrm{PhCHCH}_{3}\right), 2.05$ [br. s, C(5)NH], 1.99-1.78 [m, $2 \mathrm{H}, \mathrm{C}(2)-$ $\left.\mathrm{HCH}_{2}\right], 1.29\left(\mathrm{~d}, J=6.9 \mathrm{~Hz}, 3 \mathrm{H}, \mathrm{CH}_{3}\right) \mathrm{ppm} .{ }^{13} \mathrm{C} \quad \mathrm{NMR}$ $\left(100.6 \mathrm{MHz}, \mathrm{CDCl}_{3}\right): \delta=177.71$ and 177.23 [s, C(4)=O], 145.68 and 145.64 [s, $\left.\mathrm{PhC}\left(1^{\prime}\right)\right], 128.82$ and $128.71\left[\mathrm{~d}, \mathrm{PhC}\left(3^{\prime}\right)\right], 126.91$ and $126.90\left[\mathrm{~d}, \mathrm{PhC}\left(2^{\prime}\right)\right], 126.65$ and 126.49 [d, $\left.\mathrm{PhC}\left(4^{\prime}\right)\right], 70.57$ and 70.37 [d, C(2)], 49.07 and 48.79 [t, C(5)], 45.34 and 45.08 [t, C(2) $\mathrm{CH}_{2}$ ], 36.55 and 36.36 [d, $\mathrm{PhCHCH}_{3}$ ], 22.91 and 22.87 (q, $\left.\mathrm{CH}_{3}\right)$ ppm. IR (neat): $\tilde{v}=3432(\mathrm{w}), 3291(\mathrm{w}), 3196(\mathrm{~m}, \mathrm{br}), 3083(\mathrm{w}), 3060(\mathrm{w})$, 3026 (w), 2960 (m), 2927 (w), 2871 (w), 1689 (s), 1602 (m), 1582 (w), 1493 (m), 1451 (m), 1376 (m), 1331 (w), 1304 (m), 1273 (m), 1203 (w), 1169 (w), 1154 (w), 1113 (w), 1081 (w), 1072 (w), 1054 (w), $1026(\mathrm{w}), 997(\mathrm{w}), 984(\mathrm{w}), 952(\mathrm{w}), 909$ (w), $884(\mathrm{w}), 863(\mathrm{w})$, 796 (m), 762 (s), 699 (s), $644(\mathrm{~m}) \mathrm{cm}^{-1}$. HRMS: calcd. for $\mathrm{C}_{12} \mathrm{H}_{17} \mathrm{~N}_{2} \mathrm{O}[\mathrm{M}+\mathrm{H}]^{+}$205.1340; found 205.1333.

( \pm )-(5S)-5-Methyl-2-(2-phenylpropyl)imidazolidin-4-one (1b): This compound was prepared as described above from Trifernal ${ }^{\circledR}$ $(1.18 \mathrm{~g}, \quad 5.0 \mathrm{mmol}), \quad$ L-alaninamide hydrochloride $(1.00 \mathrm{~g}$, $8.0 \mathrm{mmol})$, TEA $(0.81 \mathrm{~g}, 1.1 \mathrm{~mL}, 8.0 \mathrm{mmol}), \mathrm{K}_{2} \mathrm{CO}_{3}(0.98 \mathrm{~g})$, and ethanol $(8 \mathrm{~mL})$. The residue was dissolved in ether, and the mixture was filtered. The filtrate was concentrated, and the residue was dried under vacuum to give a colorless oil ( $1.87 \mathrm{~g}$, quantitative) as a mixture of diastereomers. ${ }^{1} \mathrm{H}$ NMR $\left(400 \mathrm{MHz}, \mathrm{CDCl}_{3}\right): \delta=7.90$, 7.71, 7.06, and 6.81 (br. s, $1 \mathrm{H}, \mathrm{NHC}=\mathrm{O}), 7.34-7.26(\mathrm{~m}, 2 \mathrm{H}, \mathrm{Ph}$ ), 7.26-7.17 (m, $3 \mathrm{H}, \mathrm{Ph}), 4.38-4.25[\mathrm{~m}, 1 \mathrm{H}, \mathrm{C}(2) \mathrm{H}], 3.57-3.35[\mathrm{~m}, 1 \mathrm{H}$, $\mathrm{C}(5) \mathrm{H}], 3.00-2.83\left(\mathrm{~m}, 1 \mathrm{H}, \mathrm{PhCHCH}_{3}\right), 2.05-1.75[\mathrm{~m}, 3 \mathrm{H}$, $\mathrm{C}(2) \mathrm{HCH}_{2}$ and $\left.\mathrm{C}(5) \mathrm{NH}\right], 1.37-1.18\left[\mathrm{~m}, 6 \mathrm{H}, \mathrm{PhCHCH}_{3}\right.$ and $\left.\mathrm{C}(5) \mathrm{CH}_{3}\right] \mathrm{ppm} .{ }^{13} \mathrm{C} \mathrm{NMR}\left(100.6 \mathrm{MHz}, \mathrm{CDCl}_{3}\right): \delta=179.65$, 179.57, 179.30, and 179.05 [s, C(4)=O], 145.78, 145.73, 145.61, and 145.58 [s, PhC(1')], 128.88, 128.79, 128.71, and 128.70 [d, $\left.\mathrm{PhC}\left(3^{\prime}\right)\right]$, $126.97,126.92(2 \mathrm{C})$, and $\left.126.87 \mathrm{~d}, \mathrm{PhC}\left(2^{\prime}\right)\right], 126.76,126.59$, 126.53, and 126.45 [d, $\left.\mathrm{PhC}\left(4^{\prime}\right)\right], 68.32,68.17,67.86$, and 67.85 [d, $\mathrm{C}(2)$ ], 55.17, 54.90, 53.80, and 53.54 [d, C(5)], 45.52, 45.48, 45.32, and $45.22\left[\mathrm{t}, \mathrm{C}(2) \mathrm{CH}_{2}\right], 36.68,36.65,36.33$, and 36.31 [d, $\mathrm{PhCHCH}_{3}$ ], 23.09, 22.94, 22.85, and 22.80 (q, $\mathrm{PhCHCH}_{3}$ ), 17.25, 17.21, 17.20, and 17.12 [q, $\left.\mathrm{C}(5) \mathrm{CH}_{3}\right] \mathrm{ppm}$. IR (neat): $\tilde{\mathrm{v}}=3202(\mathrm{~m}$, br.), 3105 (w), 3084 (w), 3061 (w), 3027 (w), 2964 (m), 2928 (m), $2870(\mathrm{~m}), 1694(\mathrm{~s}), 1602(\mathrm{~m}), 1582(\mathrm{w}), 1493(\mathrm{~m}), 1451(\mathrm{~m}), 1371$ (m), 1338 (w), $1321(\mathrm{w}), 1294(\mathrm{~m}), 1260(\mathrm{w}), 1198$ (w), $1182(\mathrm{w})$, $1134(\mathrm{~m}), 1059(\mathrm{~m}), 1025(\mathrm{~m}), 999(\mathrm{w}), 973(\mathrm{w}), 932(\mathrm{w}), 911(\mathrm{w})$, 880 (w), 843 (w), 762 (s), 699 (s), 619 (w), 606 (w) cm ${ }^{-1}$. HRMS: calcd. for $\mathrm{C}_{13} \mathrm{H}_{19} \mathrm{~N}_{2} \mathrm{O}[\mathrm{M}+\mathrm{H}]^{+}$219.1497; found 219.1488.

( \pm )-(5S)-5-Benzyl-2-(2-phenylpropyl)imidazolidin-4-one (1c): This compound was prepared as described above from Trifernal ${ }^{\circledR}$ $(0.74 \mathrm{~g}, 5.0 \mathrm{mmol})$, L-phenylalaninamide hydrochloride $(1.00 \mathrm{~g}$, $5.0 \mathrm{mmol})$, TEA $(0.505 \mathrm{~g}, 0.7 \mathrm{~mL}, 5.0 \mathrm{mmol}), \mathrm{K}_{2} \mathrm{CO}_{3}(0.98 \mathrm{~g})$, and ethanol $(8 \mathrm{~mL})$. Removing the solvent and drying under vacuum gave a highly viscous, slightly yellow oil $(1.41 \mathrm{~g}, 96 \%)$ as a mixture of diastereomers. ${ }^{1} \mathrm{H}$ NMR $\left(400 \mathrm{MHz}, \mathrm{CDCl}_{3}\right): \delta=7.67,7.63,6.77$, and $6.69(\mathrm{~s}, 1 \mathrm{H}, \mathrm{NHC}=\mathrm{O}), 7.36-7.11(\mathrm{~m}, 10 \mathrm{H}, \mathrm{Ph}), 4.35-4.25$ and 4.14-4.06 [m, $1 \mathrm{H}, \mathrm{C}(2) \mathrm{H}], 3.78-3.67$ and 3.67-3.58 [m, $1 \mathrm{H}, \mathrm{C}(5)$ $\mathrm{H}], 3.16-3.08,3.07-3.02$, and $2.93-2.77\left[\mathrm{~m}, 2 \mathrm{H}, \mathrm{C}(5) \mathrm{CH}_{2}\right], 2.93-$ $2.77[\mathrm{~m}, 1 \mathrm{H}, \mathrm{PhCHCH}$ ], 2.04 [br. s, $1 \mathrm{H}, \mathrm{C}(5) \mathrm{NH}$ ] $1.92-1.65$ and $1.62-1.52\left[\mathrm{~m}, 2 \mathrm{H}, \mathrm{C}(2) \mathrm{CH}_{2}\right], 1.28-1.20\left[\mathrm{~m}, 3 \mathrm{H}, \mathrm{PhCHCH}_{3}\right] \mathrm{ppm}$. ${ }^{13} \mathrm{C}$ NMR $\left(100.6 \mathrm{MHz}, \mathrm{CDCl}_{3}\right): \delta=177.85,177.71,177.54$, and 177.18 [s, C(1)=O], 145.63 [s, $\left.\mathrm{PhC}\left(1^{\prime}\right)\right], 137.57,137.40,137.32$, and 137.29 [s, PhC $\left.\left(1^{\prime \prime}\right)\right], 129.49$ (2 C), 129.42, and 129.41 [d, $\left.\mathrm{PhC}\left(2^{\prime \prime}\right)\right]$, $128.85,128.77,128.69$, and 128.67 [d, $\left.\mathrm{PhC}\left(3^{\prime}\right)\right], 128.59$ and 128.53 (3 C) [d, $\left.\mathrm{PhC}\left(3^{\prime \prime}\right)\right], 126.92,126.90$, and 126.87 (2 C) [d, $\left.\mathrm{PhC}\left(2^{\prime}\right)\right]$, 126.72 (3 C), 126.70 (2 C), 126.62, 126.47, and 126.46 [d, PhC( $\left.4^{\prime}\right)$ and $\mathrm{PhC}\left(4^{\prime \prime}\right)$ ], 68.35, 68.31, 68.12, and 67.97 [d, $\left.\mathrm{C}(2)\right], 60.32,60.70$, 59.28 , and $59.20[\mathrm{~d}, \mathrm{C}(5)], 45.68,45.58,45.48$, and $45.46[\mathrm{t}$, $\left.\mathrm{C}(2) \mathrm{CH}_{2}\right], 37.59,37.37,37.20$, and 37.12 [t, $\left.\mathrm{C}(5) \mathrm{CH}_{2}\right], 36.55,36.54$, and 36.33 (2 C) [d, $\left.\mathrm{PhCHCH}_{3}\right], 22.99,22.92,22.84$, and 22.80 (q, $\mathrm{PhCHCH}_{3}$ ) ppm. IR (neat): $\tilde{v}=3660$ (w), 3194 (m, br.), 3084 (w), 3061 (w), 3026 (m), 3001 (w), 2958 (m), 2924 (m), 2870 (w), 1947 (w), 1879 (w), $1810(\mathrm{w}), 1695$ (s), $1602(\mathrm{~m}), 1582(\mathrm{w}), 1494(\mathrm{~m})$, 1452 (m), 1374 (m), 1342 (m), 1281 (m), 1202 (w), 1182 (w), 1155 (w), 1117 (m), 1077 (m), 1066 (w), 1057 (w), 1027 (m), 1000 (w), 970 (w), 911 (w), $877(\mathrm{w}), 762(\mathrm{~m}), 752(\mathrm{~m}), 697$ (s), $620(\mathrm{w}) \mathrm{cm}^{-1}$. HRMS: calcd. for $\mathrm{C}_{19} \mathrm{H}_{23} \mathrm{~N}_{2} \mathrm{O}[\mathrm{M}+\mathrm{H}]^{+}$295.1810; found 295.1804 . 
( \pm )-(7aS)-3-(2-Phenylpropyl)hexahydro-1 $H$-pyrrolo[1,2-c|imidazol1-one (1d): This compound was prepared as described above (without TEA) from Trifernal ${ }^{\circledR}(0.65 \mathrm{~g}, 4.4 \mathrm{mmol})$, D-prolinamide (0.50 g, $4.4 \mathrm{mmol}), \mathrm{K}_{2} \mathrm{CO}_{3}$, and ethanol (4.48 g) to yield a colorless oil $(1.03 \mathrm{~g}, 97 \%)$ as a mixture of diastereomers. ${ }^{1} \mathrm{H}$ NMR (400 MHz, [D $\left.\left.{ }_{6}\right] \mathrm{DMSO}\right): \delta=8.23$ (br. s, $1 \mathrm{H}, \mathrm{NHC}=\mathrm{O}$ ), 7.35-7.14 $(\mathrm{m}, 5 \mathrm{H}, \mathrm{Ph}), 3.81(\mathrm{t}, J=6.1 \mathrm{~Hz}$ ) and $3.68[\mathrm{dd}, J=8.7,4.1 \mathrm{~Hz}, 1 \mathrm{H}, \mathrm{C}(3)-$ $\mathrm{H}$ ], 3.52 [ddd, $J=14.6,10.3,4.1 \mathrm{~Hz}, 1 \mathrm{H}, \mathrm{C}(7 \mathrm{a}) \mathrm{H}$ ], 3.04-2.85 [m, $2 \mathrm{H}, \mathrm{C}(5) \mathrm{H}$ and $\left.\mathrm{CHCH}_{3}\right], 2.53-2.37[\mathrm{~m}, 1 \mathrm{H}, \mathrm{C}(5) \mathrm{H}], 1.96-1.81[\mathrm{~m}$, $1 \mathrm{H}, \mathrm{C}(7) \mathrm{H}], 1.81-1.49\left[\mathrm{~m}, 5 \mathrm{H}, \mathrm{C}(7) \mathrm{H}, \mathrm{C}(6) \mathrm{H}_{2}\right.$, and $\mathrm{C}(3) \mathrm{HCH}_{2}$, 1.21 and $1.20\left(\mathrm{~d}, J=7.2 \mathrm{~Hz}, 3 \mathrm{H}, \mathrm{CH}_{3}\right) \mathrm{ppm} .{ }^{13} \mathrm{C} \mathrm{NMR}$ (100.6 MHz, [D 6 ]DMSO): $\delta=176.25$ and 176.09 [s, C(1)=O], 146.74 and 146.51 [s, $\left.\mathrm{PhC}\left(1^{\prime}\right)\right], 128.39$ and 128.28 [d, $\left.\mathrm{PhC}\left(3^{\prime}\right)\right]$, 126.86 and 126.76 [d, $\left.\operatorname{PhC}\left(2^{\prime}\right)\right], 125.97$ and 125.84 [d, $\left.\mathrm{PhC}\left(4^{\prime}\right)\right]$, 75.14 and 75.12 [d, C(3)], 62.61 and 62.45 [d, C(7a)], 55.59 and 55.24 [t, $\mathrm{C}(5)], 46.64$ and 46.12 [t, $\left.\mathrm{C}(3) \mathrm{CH}_{2}\right], 35.54$ and 34.88 [d, $\mathrm{PhCHCH}_{3}$ ], 27.19 and 27.14 [t, C(7)], 24.60 and 24.48 [t, C(6)], 22.77 and $22.17\left(\mathrm{q}, \mathrm{CH}_{3}\right) \mathrm{ppm}$. IR (neat): $\tilde{\mathrm{v}}=3675(\mathrm{w}), 3184$ (w, br.), 3083 (w), 3061 (w), $3026(w), 2960$ (m), 2927 (w), $2870(w)$, 2818 (w), 1994 (s), 1602 (w), 1582 (w), 1494 (m), 1451 (m), 1375 (m), $1329(\mathrm{~m}), 1305(\mathrm{w}), 1274(\mathrm{~m}), 1249(\mathrm{~m}), 1186(\mathrm{w}), 1164(\mathrm{w})$, $1115(\mathrm{~m}), 1099(\mathrm{~m}), 1074(\mathrm{w}), 1049$ (w), $1026(\mathrm{~m}), 1000(\mathrm{w}), 987$ (w), $907(\mathrm{w}), 878(\mathrm{w}), 762(\mathrm{~s}), 699(\mathrm{~s}) \mathrm{cm}^{-1}$. HRMS: calcd. for $\mathrm{C}_{15} \mathrm{H}_{21} \mathrm{~N}_{2} \mathrm{O}[\mathrm{M}+\mathrm{H}]^{+}$245.1658; found 245.1653.

General Method for the Preparation of Imidazolidin-4-ones 2-9: The carbonyl compound and TEA were added to a suspension of the amino acid amide hydrochloride in dry methanol. The mixture was heated at reflux for $18 \mathrm{~h}$. After cooling to room temp. and, in some cases, stirring for $24 \mathrm{~h}$, the solvent was removed under reduced pressure. Then, demineralized water $(20-25 \mathrm{~mL})$ was added to the residue, and the mixture extracted with ethyl acetate $(3 \times 20$ $25 \mathrm{~mL}$ ). The combined organic phases were dried with $\mathrm{Na}_{2} \mathrm{SO}_{4}$ and concentrated, and the residue was dried under high vacuum ( $0.2 \mathrm{mbar}, 1 \mathrm{~h}$ at room temperature) to give the imidazolidin-4-one, usually as a mixture of diastereomers.

( \pm )-2-(2,4,4-Trimethylpentyl)imidazolidin-4-one (2a): This compound was prepared as described above from $( \pm)-3,5,5$-trimethylhexanal $(2.58 \mathrm{~g}, 18.1 \mathrm{mmol})$, TEA $(2.00 \mathrm{~g}, 19.8 \mathrm{mmol}, 2.7 \mathrm{~mL})$, glycinamide hydrochloride $(2.00 \mathrm{~g}, 18.1 \mathrm{mmol})$, and dry methanol $(20 \mathrm{~mL})$ to give, after additional drying $\left(0.5 \mathrm{~h}\right.$ at $\left.60^{\circ} \mathrm{C}\right)$, a yellow paste $(3.44 \mathrm{~g}, 96 \%) .{ }^{1} \mathrm{H}$ NMR $\left(400 \mathrm{MHz}, \mathrm{CDCl}_{3}\right): \delta=7.90$ and 7.62 (br. s, $1 \mathrm{H}, \mathrm{NHC}=\mathrm{O}$ ), $4.70-4.61[\mathrm{~m}, 1 \mathrm{H}, \mathrm{C}(2) \mathrm{H}], 3.50-3.33$ $\left[\mathrm{m}, 2 \mathrm{H}, \mathrm{C}(5) \mathrm{H}_{2}\right], 2.58$ [br. s, $\left.1 \mathrm{H}, \mathrm{C}(5) \mathrm{NH}\right], 1.78-1.63[\mathrm{~m}, 1 \mathrm{H}$, $\left.\mathrm{C}\left(2^{\prime}\right) \mathrm{H}\right], 1.63-1.41\left[\mathrm{~m}, 2 \mathrm{H}, \mathrm{C}\left(1^{\prime}\right) \mathrm{H}_{2}\right], 1.31-1.05\left[\mathrm{~m}, 2 \mathrm{H}, \mathrm{C}\left(3^{\prime}\right) \mathrm{H}_{2}\right]$, 0.99 and $0.98\left[\mathrm{~d}, J=6.7 \mathrm{~Hz}, 3 \mathrm{H}, \mathrm{C}\left(2^{\prime}\right) \mathrm{CH}_{3}\right], 0.91$ and $0.90[\mathrm{~s}, 9$ $\left.\mathrm{H}, \mathrm{C}\left(4^{\prime}\right) \mathrm{CH}_{3}\right] \mathrm{ppm} .{ }^{13} \mathrm{C} \mathrm{NMR}\left(100.6 \mathrm{MHz}, \mathrm{CDCl}_{3}\right): \delta=177.74$ and $177.69[\mathrm{~s}, \mathrm{C}(4)=\mathrm{O}], 70.42$ and $70.39[\mathrm{~d}, \mathrm{C}(2)], 51.44$ and $51.35[\mathrm{t}$, $\mathrm{C}\left(3^{\prime}\right)$ ], 49.16 and 49.08 [t, C(5)], 46.62 and 46.35 [t, C(1')], 31.15 [s, $\mathrm{C}\left(4^{\prime}\right)$ ], 29.98 and 29.96 [q, $\mathrm{C}\left(4^{\prime}\right) \mathrm{CH}_{3}$ ], 25.95 and 25.82 [d, $\mathrm{C}\left(2^{\prime}\right)$ ], 22.70 and 22.62 [q, $\mathrm{C}\left(2^{\prime}\right) \mathrm{CH}_{3}$ ] ppm. IR (neat): $\tilde{v}=3198$ (m, br.), 2951 (s), 2904 (m), 2867 (m), 1692 (s), 1538 (w), 1475 (w), 1466 (m), 1392 (m), 1377 (w), 1364 (s), 1315 (m), 1299 (m), 1280 (m), 1247 (m), 1200 (m), 1136 (w), 1113 (w), 1096 (w), 1054 (w), 1017 (w), $973(\mathrm{~m}), 947(\mathrm{w}), 927(\mathrm{w}), 911(\mathrm{w}), 865(\mathrm{~m}), 746(\mathrm{~m}), 695(\mathrm{~m})$, $654(\mathrm{~m}), 615(\mathrm{w}) \mathrm{cm}^{-1}$. HRMS: calcd. for $\mathrm{C}_{11} \mathrm{H}_{23} \mathrm{~N}_{2} \mathrm{O}[\mathrm{M}+\mathrm{H}]^{+}$ 199.1805; found 199.1854.

( \pm )-(5S)-5-Methyl-2-(2,4,4-trimethylpentyl)imidazolidin-4-one (2b): This compound was prepared as described above from $( \pm)-3,5,5-$ trimethylhexanal (1.16 g, $8.1 \mathrm{mmol})$, TEA $(0.89 \mathrm{~g}, 8.8 \mathrm{mmol})$, L-alaninamide hydrochloride $(1.00 \mathrm{~g}, 8.0 \mathrm{mmol})$, and dry methanol $(10 \mathrm{~mL})$. Plug filtration $\left(\mathrm{SiO}_{2}\right.$, ethyl acetate) of the crude compound followed by concentrating the mixture and drying the resi- due under high vacuum $(0.2 \mathrm{mbar}, 1 \mathrm{~h})$ gave a white solid (1.26 $\mathrm{g}$, $74 \%$ ). ${ }^{1} \mathrm{H}$ NMR $\left(400 \mathrm{MHz}, \mathrm{CDCl}_{3}\right): \delta=7.64,7.58,7.35$, and 7.23 (br. s, $1 \mathrm{H}, \mathrm{NHC}=\mathrm{O}), 4.644 .53[\mathrm{~m}, 1 \mathrm{H}, \mathrm{C}(2) \mathrm{H}], 3.59-3.42[\mathrm{~m}, 1$ $\mathrm{H}, \mathrm{C}(5) \mathrm{H}], 1.96$ [br. s, $1 \mathrm{H}, \mathrm{C}(5) \mathrm{NH}], 1.78-1.61\left[\mathrm{~m}, 1 \mathrm{H}, \mathrm{C}\left(2^{\prime}\right) \mathrm{H}\right]$, $1.61-1.37\left[\mathrm{~m}, 2 \mathrm{H}, \mathrm{C}\left(1^{\prime}\right) \mathrm{H}_{2}\right], 1.35,1.34,1.32$, and 1.32 [d, $J=6.7-$ $\left.6.9 \mathrm{~Hz}, 3 \mathrm{H}, \mathrm{C}(5) \mathrm{CH}_{3}\right], 1.27-1.04\left[\mathrm{~m}, 2 \mathrm{H}, \mathrm{C}\left(3^{\prime}\right) \mathrm{H}_{2}\right], 0.99,0.99$, 0.98 , and 0.97 [d, $\left.J=6.4-6.7 \mathrm{~Hz}, 3 \mathrm{H}, \mathrm{C}\left(2^{\prime}\right) \mathrm{CH}_{3}\right], 0.91,0.91,0.91$, and $0.90\left[\mathrm{~s}, 9 \mathrm{H}, \mathrm{C}\left(4^{\prime}\right) \mathrm{CH}_{3}\right] \mathrm{ppm} .{ }^{13} \mathrm{C} \mathrm{NMR}\left(100.6 \mathrm{MHz}, \mathrm{CDCl}_{3}\right)$ : $\delta=179.66$ and 179.50 [s, C(4)=O], 67.96, 67.94, and 67.91 [d, C(2)], 55.39, 53.86, and 53.77 [d, C(5)], 51.63, 51.37, and 51.33 [t, C( $\left.3^{\prime}\right)$ ], $46.99,46.74,46.70$, and 46.58 [t, $\left.\mathrm{C}\left(1^{\prime}\right)\right], 31.18$ and 31.16 [s, C(4')], 29.99, 29.98, and 29.95 [q, $\mathrm{C}\left(4^{\prime}\right) \mathrm{CH}_{3}$ ] $, 26.08,25.94$, and 25.88 [d, $\mathrm{C}\left(2^{\prime}\right)$ ], 22.82, 22.64, 22.63, and 22.57 [q, $\left.\mathrm{C}\left(2^{\prime}\right) \mathrm{CH}_{3}\right], 17.14,17.11$, and 17.03 [q, $\mathrm{C}(5) \mathrm{CH}_{3}$ ] ppm. IR (neat): $\tilde{\mathrm{v}}=3676$ (w, br.), 3251 (w), 3187 (w, br.), 3094 (w), 2951 (m), 2903 (m), 2867 (m), 1701 (s), 1475 (w), 1452 (m), 1388 (w), 1376 (w), 1365 (m), 1327 (w), 1294 (m), 1247 (w), 1198 (w), $1180(\mathrm{w}), 1135$ (m), $1091(\mathrm{w}), 1077$ (w), $1060(\mathrm{w}), 1037(\mathrm{w}), 981(\mathrm{w}), 966(\mathrm{w}), 930(\mathrm{w}), 900(\mathrm{w}), 878(\mathrm{w}), 849$ (w), $835(\mathrm{w}), 797(\mathrm{w}), 767(\mathrm{~m}), 720(\mathrm{w}), 689(\mathrm{w}), 656(\mathrm{w}), 614$ (w) $\mathrm{cm}^{-1}$. HRMS: calcd. for $\mathrm{C}_{12} \mathrm{H}_{25} \mathrm{~N}_{2} \mathrm{O}[\mathrm{M}+\mathrm{H}]^{+} 213.1967$; found 213.1981.

( \pm )-(5S)-5-Benzyl-2-(2,4,4-trimethylpentyl)imidazolidin-4-one (2c): This compound was prepared as described above from $( \pm)-3,5,5-$ trimethylhexanal $(0.64 \mathrm{~g}, 4.5 \mathrm{mmol})$, TEA $(0.50 \mathrm{~g}, 5.0 \mathrm{mmol})$, Lphenylalaninamide hydrochloride $(0.74 \mathrm{~g}, 4.5 \mathrm{mmol})$, and dry methanol $(6 \mathrm{~mL})$ to give a highly viscous, yellow oil $(1.23 \mathrm{~g}, 95 \%)$. ${ }^{1} \mathrm{H}$ NMR (400 MHz, $\mathrm{CDCl}_{3}$ ): $\delta=7.66,7.51$, and 7.34-7.20 (br. s, $1 \mathrm{H}, \mathrm{NHC}=\mathrm{O}), 7.34-7.20(\mathrm{~m}, 5 \mathrm{H}, \mathrm{Ph}), 4.56-4.50,4.45-4.39$, 4.364.31, and 4.30-4.24 [m, 1 H, C(2)H], 3.80-3.69 [m, $1 \mathrm{H}, \mathrm{C}(5) \mathrm{H}]$, 3.19-2.89 [m, $2 \mathrm{H}, \mathrm{C}(5) \mathrm{CH}_{2}$ ], 2.55 [br. s, $\left.1 \mathrm{H}, \mathrm{C}(5) \mathrm{NH}\right], 1.68-1.54$ $\left[\mathrm{m}, 1 \mathrm{H}, \mathrm{C}\left(2^{\prime}\right) \mathrm{H}\right], 1.54-1.20\left[\mathrm{~m}, 2 \mathrm{H}, \mathrm{C}\left(1^{\prime}\right) \mathrm{H}_{2}\right], 1.20-0.99[\mathrm{~m}, 2 \mathrm{H}$, $\left.\mathrm{C}\left(3^{\prime}\right) \mathrm{H}_{2}\right], 0.95-0.84\left[\mathrm{~m}, 12 \mathrm{H}, \mathrm{C}\left(2^{\prime}\right) \mathrm{CH}_{3}\right.$ and $\left.\mathrm{C}\left(4^{\prime}\right) \mathrm{CH}_{3}\right] \mathrm{ppm} .{ }^{13} \mathrm{C}$ NMR (100.6 MHz, $\left.\mathrm{CDCl}_{3}\right): \delta=178.03,177.97,177.93$, and 177.69 $[\mathrm{s}, \mathrm{C}(4)=\mathrm{O}], 137.51,137.47,137.34$, and $137.15\left[\mathrm{~s}, \mathrm{PhC}\left(1^{\prime}\right)\right], 129.60$, 129.56, 129.55, and 129.44 [d, $\mathrm{PhC}\left(2^{\prime}\right)$ ], 128.65, 128.61, 128.53, and 128.49 [d, $\left.\mathrm{PhC}\left(3^{\prime}\right)\right], 126.80,126.78$, and 126.73 [d, $\left.\mathrm{PhC}\left(4^{\prime}\right)\right], 68.26$, 68.11, 68.01, and 67.88 [d, C(2)], 60.40, 60.30, 59.57, and 59.43 [d, $\mathrm{C}(5)], 51.63,51.39,51.25$, and 51.17 [t, C(3')], 47.04, 46.85 (2 C), and $46.72\left[\mathrm{t}, \mathrm{C}\left(1^{\prime}\right)\right], 37.31,37.28,37.18$, and $36.94\left[\mathrm{t}, \mathrm{C}(5) \mathrm{CH}_{2}\right]$, $31.15,31.14$, and 31.09 [s, $\mathrm{C}\left(4^{\prime}\right)$ ], 29.99 and 29.96 [q, $\mathrm{C}\left(4^{\prime}\right) \mathrm{CH}_{3}$ ], $25.96,25.82,25.81$, and 25.58 [d, $\left.\mathrm{C}\left(2^{\prime}\right)\right], 22.76,22.67$ (2 C), and 22.57 [q, $\mathrm{C}\left(2^{\prime}\right) \mathrm{CH}_{3}$ ] ppm. IR (neat): $\tilde{v}=3726(\mathrm{w}), 3627(\mathrm{w}), 3200$ (w, br.), $3086(\mathrm{w}), 3063$ (w), 3029 (w), 2951 (m), 2905 (m), 2867 (m), 1944 (w), 1699 (s), 1603 (w), 1584 (w), 1541 (w), 1496 (m), 1475 (w), 1464 (w), 1454 (m), 1438 (w), 1393 (w), $1364(\mathrm{~m}), 1265$ (w), $1244(\mathrm{~m}), 1201(\mathrm{w}), 1120(\mathrm{~m}), 1078(\mathrm{w}), 1047(\mathrm{w}), 1030(\mathrm{w})$, $973(\mathrm{w}), 916(\mathrm{w}), 775(\mathrm{~m}), 749(\mathrm{~m}), 728(\mathrm{w}), 697(\mathrm{~s}), 663(\mathrm{~m}), 648$ (w), $621(\mathrm{w}), 611(\mathrm{w}) \mathrm{cm}^{-1}$. HRMS: calcd. for $\mathrm{C}_{18} \mathrm{H}_{29} \mathrm{~N}_{2} \mathrm{O}$ $[\mathrm{M}+\mathrm{H}]^{+}$289.2274; found 289.2244.

( \pm )-(7aS)-3-(2,4,4-Trimethylpentyl)hexahydro-1 $H$-pyrrolo[1,2-c]imidazol-1-one (2d): This compound was prepared as described above from ( \pm )-3,5,5-trimethylhexanal $(0.99 \mathrm{~g}, 7.0 \mathrm{mmol})$, TEA $(1.07 \mathrm{~g}, 10.6 \mathrm{mmol})$, D-prolinamide $(0.80 \mathrm{~g}, 7.0 \mathrm{mmol})$, and dry methanol $(10 \mathrm{~mL})$ to give a viscous, slightly yellow oil $(1.63 \mathrm{~g}$, $98 \%$ ). ${ }^{1} \mathrm{H}$ NMR (400 MHz, $\mathrm{CDCl}_{3}$ ): $\delta=8.01$ and 7.64 (br. s, $1 \mathrm{H}$, $\mathrm{NHC}=\mathrm{O}), 4.22-4.13[\mathrm{~m}, 1 \mathrm{H}, \mathrm{C}(3) \mathrm{H}], 3.79-3.68[\mathrm{~m}, 1 \mathrm{H}, \mathrm{C}(7 \mathrm{a}) \mathrm{H}]$, 3.22-3.12 [m, $1 \mathrm{H}, \mathrm{C}(5) \mathrm{H}], 2.74-2.63[\mathrm{~m}, 1 \mathrm{H}, \mathrm{C}(5) \mathrm{H}], 2.16-2.02$ $[\mathrm{m}, 1 \mathrm{H}, \mathrm{C}(7) \mathrm{H}], 2.03-1.89[\mathrm{~m}, 1 \mathrm{H}, \mathrm{C}(7) \mathrm{H}], 1.86-1.70[\mathrm{~m}, 2 \mathrm{H}$, $\left.\mathrm{C}(6) \mathrm{H}_{2}\right], 1.86-1.70$ and $1.70-1.62\left[\mathrm{~m}, 1 \mathrm{H}, \mathrm{C}\left(2^{\prime}\right) \mathrm{H}\right], 1.62-1.28[3 \mathrm{~m}$, $2 \mathrm{H}, \mathrm{C}\left(1^{\prime}\right) \mathrm{H}_{2}$ ], 1.24 [dt, $J=14.1,4.0 \mathrm{~Hz}, 1 \mathrm{H}, \mathrm{C}\left(3^{\prime}\right) \mathrm{H}$ ] 1.09 [ddd, $\left.J=13.9,6.4,2.4 \mathrm{~Hz}, 1 \mathrm{H}, \mathrm{C}\left(3^{\prime}\right) \mathrm{H}\right], 0.98$ and $0.96[\mathrm{~d}, J=6.7 \mathrm{~Hz}, 3$ $\left.\mathrm{H}, \mathrm{C}\left(2^{\prime}\right) \mathrm{CH}_{3}\right], 0.91$ and $0.90\left[\mathrm{~s}, 9 \mathrm{H}, \mathrm{C}\left(4^{\prime}\right) \mathrm{CH}_{3}\right] \mathrm{ppm} .{ }^{13} \mathrm{C} \mathrm{NMR}$ $\left(100.6 \mathrm{MHz}, \mathrm{CDCl}_{3}\right): \delta=178.72$ and 178.68 [s, $\left.\mathrm{C}(1)=\mathrm{O}\right], 76.48$ and 
76.36 [d, C(3)], 63.36 and 63.24 [d, C(7a)], 56.31 and 56.09 [t, C(5)], 51.35 and 51.20 [t, $\left.\mathrm{C}\left(3^{\prime}\right)\right], 47.94$ and 47.81 [t, C $\left.\left(1^{\prime}\right)\right], 31.16$ [s, C( $\left.4^{\prime}\right)$ ], 30.09 and 30.07 [q, $\mathrm{C}\left(4^{\prime}\right) \mathrm{CH}_{3}$ ], 27.67 and 27.42 [t, $\left.\mathrm{C}(7)\right], 25.70$ and $25.58\left[\mathrm{~d}, \mathrm{C}\left(2^{\prime}\right)\right], 25.13$ and 25.04 [t, C(6)], 22.90 and 22.52 [q, $\left.\mathrm{C}\left(2^{\prime}\right) \mathrm{CH}_{3}\right]$ ppm. IR (neat): $\tilde{v}=3187$ (m, br.), 3090 (w, br.), 2950 (m), 2908 (w), 2868 (m), 1698 (s), 1476 (w), 1465 (m), 1447 (m), 1392 (w), 1375 (w), 1364 (m), $1326(\mathrm{~m}), 1305$ (w), $1275(\mathrm{w}), 1246$ (m), $1188(\mathrm{~m}), 1164(\mathrm{w}), 1141(\mathrm{~m}), 1114(\mathrm{~m}), 1084(\mathrm{~m}), 1029(\mathrm{w})$, $988(\mathrm{w}), 972(\mathrm{w}), 928(\mathrm{w}), 906(\mathrm{w}), 877(\mathrm{w}), 781(\mathrm{~m}), 752(\mathrm{~m}), 698$ (m), $621(\mathrm{w}), 616(\mathrm{w}) \mathrm{cm}^{-1}$. HRMS: calcd. for $\mathrm{C}_{14} \mathrm{H}_{27} \mathrm{~N}_{2} \mathrm{O}$ $[\mathrm{M}+\mathrm{H}]^{+}$239.2118; found 239.1970 and 239.2039.

( \pm )-2-[( $R)$-2,6-Dimethyl-5-heptenyl]imidazolidin-4-one (3a): This compound was prepared as described above from $(R)-3,7$-dimethyl6-octenal [ $(R)$-citronellal, $2.10 \mathrm{~g}, 13.6 \mathrm{mmol}]$, TEA $(1.48 \mathrm{~g}$, $14.6 \mathrm{mmol}, 2.0 \mathrm{~mL})$, glycinamide hydrochloride $(1.50 \mathrm{~g}$, $13.6 \mathrm{mmol})$, and dry methanol $(15 \mathrm{~mL})$ to give a brown paste $(2.22 \mathrm{~g})$. Plug filtration $\left(\mathrm{SiO}_{2}\right.$, ethyl acetate) yielded a viscous, yellow oil $(0.38 \mathrm{~g}, 13 \%$; approximate ratio of diastereomers, $1.5: 1) .{ }^{1} \mathrm{H}$ NMR (400 MHz, $\mathrm{CDCl}_{3}$ ): $\delta=7.65$ (minor isomer) and 7.58 (major isomer, br. s, $1 \mathrm{H}, \mathrm{NHC}=\mathrm{O}), 5.15-5.01\left[\mathrm{~m}, 1 \mathrm{H}, \mathrm{C}\left(5^{\prime}\right) \mathrm{H}\right], 4.74-4.65$ $[\mathrm{m}, 1 \mathrm{H}, \mathrm{C}(2) \mathrm{H}$ ], 3.43 (minor isomer) and 3.42 [major isomer, q, $J$ $=15.5,15.2 \mathrm{~Hz}, 2 \mathrm{H}, \mathrm{C}(5) \mathrm{H}_{2}$ ], 3.29 [br. s, $1 \mathrm{H}, \mathrm{C}(5) \mathrm{NH}$, 2.08-1.87 $\left[\mathrm{m}, 2 \mathrm{H}, \mathrm{C}\left(4^{\prime}\right) \mathrm{H}_{2}\right], 1.68\left[\mathrm{~s}, 3 \mathrm{H}, \mathrm{C}\left(6^{\prime}\right) \mathrm{CH}_{3}\right.$ (trans) $], 1.68-1.55[\mathrm{~m}, 2$ $\mathrm{H}, \mathrm{C}\left(1^{\prime}\right) \mathrm{H}$ and $\left.\mathrm{C}\left(2^{\prime}\right) \mathrm{H}\right], 1.60\left[\mathrm{~s}, 3 \mathrm{H}, \mathrm{C}\left(6^{\prime}\right) \mathrm{CH}_{3}(\right.$ cis $\left.)\right], 1.52-1.41[\mathrm{~m}$, $\left.1 \mathrm{H}, \mathrm{C}\left(1^{\prime}\right) \mathrm{H}\right], 1.41-1.30\left[\mathrm{~m}, 1 \mathrm{H}, \mathrm{C}\left(3^{\prime}\right) \mathrm{H}\right], 1.28-1.14$ [m, $1 \mathrm{H}, \mathrm{C}\left(3^{\prime}\right)$ $\mathrm{H}$ ], 0.96 (minor isomer) and 0.95 [major isomer, d, $J=6.1,6.7 \mathrm{~Hz}$, $\left.3 \mathrm{H}, \mathrm{C}\left(2^{\prime}\right) \mathrm{CH}_{3}\right] \mathrm{ppm} .{ }^{13} \mathrm{C} \mathrm{NMR}\left(100.6 \mathrm{MHz}, \mathrm{CDCl}_{3}\right.$, major isomer): $\delta=177.69$ [s, C(4)=O], $131.61\left[\mathrm{~s}, \mathrm{C}\left(6^{\prime}\right)\right], 124.29$ [d, $\left.\mathrm{C}\left(5^{\prime}\right)\right]$, 70.34 [d, C(2)], 49.08 [t, C(5)], 44.00 [t, C ( (1') ], 37.10 [t, C(3')], 28.95 [d, $\left.\mathrm{C}\left(2^{\prime}\right)\right], 25.72$ [q, $\mathrm{C}\left(6^{\prime}\right) \mathrm{CH}_{3}$ (trans)], 25.25 [t, $\left.\mathrm{C}\left(4^{\prime}\right)\right], 19.61$ [q, $\mathrm{C}\left(2^{\prime}\right) \mathrm{CH}_{3}$ ], 17.69 [q, $\left.\mathrm{C}\left(6^{\prime}\right) \mathrm{CH}_{3}(c i s)\right]$ ppm. ${ }^{13} \mathrm{C}$ NMR $(100.6 \mathrm{MHz}$, $\mathrm{CDCl}_{3}$, minor isomer): $\delta=177.72[\mathrm{~s}, \mathrm{C}(4)=\mathrm{O}], 131.61\left[\mathrm{~s}, \mathrm{C}\left(6^{\prime}\right)\right]$, $124.26\left[\mathrm{~d}, \mathrm{C}\left(5^{\prime}\right)\right], 70.40[\mathrm{~d}, \mathrm{C}(2)], 49.10$ [t, C(5)], 44.03 [t, C(1')], 37.33 [t, $\left.\mathrm{C}\left(3^{\prime}\right)\right], 29.20$ [d, $\left.\mathrm{C}\left(2^{\prime}\right)\right], 25.72$ [q, $\mathrm{C}\left(6^{\prime}\right) \mathrm{CH}_{3}$ (trans)], 25.21 [t, $\left.\mathrm{C}\left(4^{\prime}\right)\right], 19.61$ [q, $\left.\mathrm{C}\left(2^{\prime}\right) \mathrm{CH}_{3}\right], 17.69$ [q, $\mathrm{C}\left(6^{\prime}\right) \mathrm{CH}_{3}($ cis $\left.)\right]$ ppm. IR (neat): $\tilde{v}=3283$ (m, br.), 3210 (m, br.), 2961 (m), 2918 (m), 2870 (w), 2854 (m), 2730 (w), 1671 (s, br.), 1533 (m, br.), 1443 (s), 1376 (s), $1334(\mathrm{w}), 1310(\mathrm{w}), 1265(\mathrm{~m}), 1179(\mathrm{w}), 1140(\mathrm{w}), 1114(\mathrm{~m})$, $1087(\mathrm{w}), 1009$ (w), $983(\mathrm{~m}), 936(\mathrm{w}), 824(\mathrm{~m}), 737(\mathrm{~m}), 641(\mathrm{~m})$, $623(\mathrm{w}), 615(\mathrm{w}), 608(\mathrm{~m}) \mathrm{cm}^{-1}$. HRMS: calcd. for $\mathrm{C}_{12} \mathrm{H}_{23} \mathrm{~N}_{2} \mathrm{O}$ [M $+\mathrm{H}]^{+}$211.1805; found 211.1772.

( \pm )-(S)-2-[(R)-2,6-Dimethylhept-5-enyl]-5-methylimidazolidin-4-one (3b): This compound was prepared as described above from $(R)$ citronellal $(0.69 \mathrm{~g}, 4.5 \mathrm{mmol})$, TEA $(0.50 \mathrm{~g}, 5.0 \mathrm{mmol})$, L-alaninamide hydrochloride $(0.56 \mathrm{~g}, 4.5 \mathrm{mmol})$, and dry methanol $(6 \mathrm{~mL})$ to give a viscous, orange oil $(0.67 \mathrm{~g})$. Plug filtration $\left(\mathrm{SiO}_{2}\right.$, ethyl acetate) followed by concentrating the mixture yielded a yellow oil $(0.25 \mathrm{~g}, 24 \%)$ which still contained small amounts of ethyl acetate. ${ }^{1} \mathrm{H} \mathrm{NMR}\left(400 \mathrm{MHz}, \mathrm{CDCl}_{3}\right): \delta=7.47$ and 7.35 (br. s, $1 \mathrm{H}$, $\mathrm{NHC}=\mathrm{O}), 5.13-5.04\left[\mathrm{~m}, 1 \mathrm{H}, \mathrm{C}\left(5^{\prime}\right) \mathrm{H}\right], 4.69-4.63$ and $4.63-4.57[\mathrm{~m}$, $1 \mathrm{H}, \mathrm{C}(2) \mathrm{H}], 3.60-3.51$ and $3.51-3.43$ [m, $1 \mathrm{H}, \mathrm{C}(5) \mathrm{H}], 2.18$ [br. s, $1 \mathrm{H}, \mathrm{C}(5) \mathrm{NH}], 2.10-1.89\left[\mathrm{~m}, 2 \mathrm{H}, \mathrm{C}\left(4^{\prime}\right) \mathrm{H}_{2}\right], 1.68$ [s, $3 \mathrm{H}, \mathrm{C}\left(6^{\prime}\right) \mathrm{CH}_{3}$ (trans)], 1.67-1.51 [m, $2 \mathrm{H}, \mathrm{C}\left(1^{\prime}\right) \mathrm{H}$ and $\left.\mathrm{C}\left(2^{\prime}\right) \mathrm{H}\right], 1.60$ [s, $3 \mathrm{H}, \mathrm{C}\left(6^{\prime}\right)-$ $\left.\mathrm{CH}_{3}(\mathrm{cis})\right], 1.51-1.14\left[\mathrm{~m}, 3 \mathrm{H}, \mathrm{C}\left(1^{\prime}\right) \mathrm{H}, \mathrm{C}\left(3^{\prime}\right) \mathrm{H}_{2}\right.$ ], 1.35 and 1.32 [d, $\left.J=6.7,7.2 \mathrm{~Hz}, 3 \mathrm{H}, \mathrm{C}(5) \mathrm{CH}_{3}\right], 0.96$ and $0.94[\mathrm{~d}, J=6.4 \mathrm{~Hz}, 3 \mathrm{H}$, $\left.\mathrm{C}\left(2^{\prime}\right) \mathrm{CH}_{3}\right] \mathrm{ppm} .{ }^{13} \mathrm{C}$ NMR $\left(100.6 \mathrm{MHz}, \mathrm{CDCl}_{3}\right): \delta=179.64$ and 179.53 [s, C (4)=O], 131.61 and $131.52\left[\mathrm{~s}, \mathrm{C}\left(6^{\prime}\right)\right], 124.38$ and 124.26 [d, C(5')], 67.96 and 67.89 [d, C(2)], 55.40 and 53.87 [d, C(5)], 44.37 and 44.28 [t, $\left.\mathrm{C}\left(1^{\prime}\right)\right], 37.31$ and 37.17 [t, $\left.\mathrm{C}\left(3^{\prime}\right)\right], 29.29$ and 29.03 [d, $\mathrm{C}\left(2^{\prime}\right)$ ], 25.72 [q, $\mathrm{C}\left(6^{\prime}\right) C \mathrm{H}_{3}$ (trans)], 25.28 and 25.27 [t, $\mathrm{C}\left(4^{\prime}\right)$ ], 19.76 and 19.54 [q, $\mathrm{C}\left(2^{\prime}\right) \mathrm{CH}_{3}$ ], 17.70 and 17.69 [q, $\mathrm{C}\left(6^{\prime}\right) \mathrm{CH}_{3}$ (cis)], 17.20 and 17.08 [q, $\mathrm{C}(5) \mathrm{CH}_{3}$ ] ppm. IR (neat): $\tilde{v}=3205$ (w, br.), 2964 (m), 2922 (m), 2871 (m), 2853 (m), 1699 (s), 1450 (m), 1376 (m), 1324 (w), 1293 (m), 1261 (w), 1177 (w), 1134 (m), 1059 (w), 1031 (w), 983 (w), 939 (w), 825 (w), 788 (m, br.), 738 (m), 692 (m), 647 (w), $632(\mathrm{w}), 604(\mathrm{~m}) \mathrm{cm}^{-1}$. HRMS: calcd. for $\mathrm{C}_{13} \mathrm{H}_{25} \mathrm{~N}_{2} \mathrm{O}[\mathrm{M}+\mathrm{H}]^{+}$ 225.1961; found 225.2004.

(5R,6S,9R)-6-Isopropyl-9-methyl-1,4-diazaspiro[4.5]decan-2-one $[(5 R, 6 S, 9 R)-4 \mathrm{a}]$ and $(5 S, 6 S, 9 R)-6$-isopropyl-9-methyl-1,4-diazaspiro[4.5]decan-2-one [ $[5 S, 6 S, 9 R)-4 a]$ : These compounds were prepared as described above from $(2 S, 5 R)$-2-isopropyl-5-methylcyclohexanone [(-)-menthone, $5.58 \mathrm{~g}, 36.2 \mathrm{mmol}]$, TEA $(5.40 \mathrm{~g}$, $53.5 \mathrm{mmol})$, glycinamide hydrochloride $(4.00 \mathrm{~g}, 36.2 \mathrm{mmol})$, and dry methanol $(30 \mathrm{~mL})$. Extraction with ethyl acetate $(3 \times 40 \mathrm{~mL})$ gave a yellow oil $(5.60 \mathrm{~g})$. Column chromatography $\left(\mathrm{SiO}_{2}\right.$, ethyl acetate) yielded $(5 R, 6 S, 9 R)-\mathbf{4 a}(0.79 \mathrm{~g}, 10 \%)$ as a slightly yellow paste and $(5 S, 6 S, 9 R)-4 \mathrm{a}(1.11 \mathrm{~g}, 15 \%)$ as colorless crystals. Data for $(5 R, 6 S, 9 R)-4 \mathrm{a}:{ }^{1} \mathrm{H}$ NMR $\left(400 \mathrm{MHz}, \mathrm{CDCl}_{3}\right): \delta=7.02$ (br. s, 1 $\mathrm{H}, \mathrm{NHC}=\mathrm{O}), 3.48\left[\mathrm{dd}, J=47.1,16.4 \mathrm{~Hz}, 2 \mathrm{H}, \mathrm{C}(3) \mathrm{H}_{2}\right.$ ], $2.03-1.94$ $[\mathrm{m}, 1 \mathrm{H}, \mathrm{C}(6) \mathrm{CH}], 1.87$ [br. s, $1 \mathrm{H}, \mathrm{C}(3) \mathrm{NH}], 1.82-1.70[\mathrm{~m}, 2 \mathrm{H}$, $\mathrm{C}(8) \mathrm{H}$ and $\mathrm{C}(10) \mathrm{H}], 1.70-1.57[\mathrm{~m}, 2 \mathrm{H}, \mathrm{C}(7) \mathrm{H}$ and $\mathrm{C}(9) \mathrm{H}], 1.44$ $1.31[\mathrm{~m}, 1 \mathrm{H}, \mathrm{C}(7) \mathrm{H}], 1.31-1.18[\mathrm{~m}, 2 \mathrm{H}, \mathrm{C}(6) \mathrm{H}$ and $\mathrm{C}(10) \mathrm{H}], 0.97-$ $0.81[\mathrm{~m}, 1 \mathrm{H}, \mathrm{C}(8) \mathrm{H}], 0.92\left[\mathrm{~d}, J=7.2 \mathrm{~Hz}, 3 \mathrm{H}, \mathrm{C}(6) \mathrm{CHCH}_{3}\right], 0.91$ $\left[\mathrm{d}, J=6.6 \mathrm{~Hz}, 3 \mathrm{H}, \mathrm{C}(6) \mathrm{CHCH}_{3}\right], 0.90[\mathrm{~d}, J=7.2 \mathrm{~Hz}, 3 \mathrm{H}$, $\left.\mathrm{C}(9) \mathrm{CH}_{3}\right] \mathrm{ppm} .{ }^{13} \mathrm{C} \mathrm{NMR}\left(100.6 \mathrm{MHz}, \mathrm{CDCl}_{3}\right): \delta=176.07[\mathrm{~s}$, $\mathrm{C}(2)=\mathrm{O}], 79.49[\mathrm{~s}, \mathrm{C}(5)], 50.52$ [d, C(6)], 49.78 [t, C(10)], 49.37 [t, $\mathrm{C}(3)$ ], 34.52 [t, C(8)], 29.52 [d, C(9)], 25.09 [d, C(6)CH], 24.19 [q, $\mathrm{C}(6) \mathrm{CHCH}_{3}$ ], 22.68 [t, $\mathrm{C}(7)$ ], 22.01 [q, $\mathrm{C}(9) \mathrm{CH}_{3}$ ], 18.64 [q, $\mathrm{C}(6)-$ $\mathrm{CHCH}_{3}$ ] ppm. IR (neat): $\tilde{v}=3322$ (w), 3189 (w, br.), 3081 (w), 2950 (m), 2924 (m), 2867 (m), 1688 (s), 1454 (m), $1441(\mathrm{w}), 1383$ (w), $1360(\mathrm{~m}), 1348(\mathrm{~m}), 1333(\mathrm{w}), 1311(\mathrm{~m}), 1297(\mathrm{w}), 1260(\mathrm{w})$, 1241 (w), 1197 (w), 1178 (w), 1159 (w), 1139 (w), 1100 (w), 1085 (w), $1056(w), 1026(w), 1005(w), 984(w), 945(w), 919(w), 894$ (w), 854 (w), 792 (w), 729 (m, br.), 681 (m), 661 (w), 639 (m), 615 (w) $\mathrm{cm}^{-1}$. HRMS: calcd. for $\mathrm{C}_{12} \mathrm{H}_{23} \mathrm{~N}_{2} \mathrm{O}[\mathrm{M}+\mathrm{H}]^{+} 211.1805$; found 211.1817. Data for $(5 S, 6 S, 9 R)-4 \mathbf{a}:{ }^{1} \mathrm{H}$ NMR $\left(400 \mathrm{MHz}, \mathrm{CDCl}_{3}\right): \delta$ $=8.86$ (br. s, $1 \mathrm{H}, \mathrm{NHC}=\mathrm{O}), 3.57$ [dd, $J=45.1,16.4 \mathrm{~Hz}, 2 \mathrm{H}, \mathrm{C}(3)-$ $\mathrm{H}_{2}$ ], 2.16-2.03 [m, 1 H, C(6)CH], 1.92 [s, $\left.1 \mathrm{H}, \mathrm{C}(3) \mathrm{NH}\right], 1.89-1.76$ $[\mathrm{m}, 2 \mathrm{H}, \mathrm{C}(8) \mathrm{H}$ and $\mathrm{C}(10) \mathrm{H}], 1.70-1.56[\mathrm{~m}, 2 \mathrm{H}, \mathrm{C}(7) \mathrm{H}$ and $\mathrm{C}(9) \mathrm{H}], 1.35-1.17$ [m, $3 \mathrm{H}, \mathrm{C}(6) \mathrm{H}, \mathrm{C}(7) \mathrm{H}$, and $\mathrm{C}(10) \mathrm{H}], 0.95-0.82$ [m, $1 \mathrm{H}, \mathrm{C}(8) \mathrm{H}], 0.94$ [d, $\left.J=7.2 \mathrm{~Hz}, 3 \mathrm{H}, \mathrm{C}(6) \mathrm{CHCH}_{3}\right], 0.91$ [d, $J$ $\left.=6.6 \mathrm{~Hz}, 3 \mathrm{H}, \mathrm{C}(9) \mathrm{CH}_{3}\right], 0.80[\mathrm{~d}, J=6.7 \mathrm{~Hz}, 3 \mathrm{H}, \mathrm{C}(6)-$ $\left.\mathrm{CHCH}_{3}\right] \mathrm{ppm} .{ }^{13} \mathrm{C} \mathrm{NMR}\left(100.6 \mathrm{MHz}, \mathrm{CDCl}_{3}\right): \delta=176.45[\mathrm{~s}$, $\mathrm{C}(2)=\mathrm{O}], 79.92$ [s, C(5)], 51.99 [d, C(6)], 50.62 [t, C(10)], 49.63 [t, $\mathrm{C}(3)$ ], 34.51 [t, C(8)], 30.14 [d, C(9)], 25.41 [d, C(6)CH], 23.97 [q, $\mathrm{C}(6) \mathrm{CHCH}_{3}$ ], 22.70 [t, $\mathrm{C}(7)$ ], 22.17 [q, $\mathrm{C}(9) \mathrm{CH}_{3}$ ], 17.94 [q, $\left.\mathrm{C}(6) \mathrm{CHCH}_{3}\right]$ ppm. IR (neat): $\tilde{v}=3331$ (w), 3166 (m, br.), 3066 (w), 2947 (m), 2918 (m), 2869 (m), 2842 (w), 1674 (s), 1447 (m), 1430 (m), 1366 (m), 1344 (m), 1334 (m), 1305 (m), $1255(\mathrm{w}), 1242(\mathrm{w})$, 1197 (w), 1179 (w), 1155 (m), 1137 (w), 1124 (w), 1096 (w), 1064 (w), $1024(w), 996(w), 974(w), 952(w), 929(w), 917(w), 897(w)$, $860(\mathrm{w}), 801(\mathrm{~m}), 765(\mathrm{~m}), 671(\mathrm{~m}), 664(\mathrm{~m}), 630(\mathrm{~m}) \mathrm{cm}^{-1}$. HRMS: calcd. for $\mathrm{C}_{12} \mathrm{H}_{23} \mathrm{~N}_{2} \mathrm{O}[\mathrm{M}+\mathrm{H}]^{+}$211.1805; found 211.1849. A pure fraction of $(5 S, 6 S, 9 R)-4 \mathbf{a}(200 \mathrm{mg})$ was dissolved in ethyl acetate $(1 \mathrm{~mL})$ and heptane $(5 \mathrm{~mL})$, and the solution was refrigerated overnight to give small crystals. Removing the solvent and dissolving the residue again in a mixture of ethyl acetate $(0.5 \mathrm{~mL})$ and heptane $(2.5 \mathrm{~mL})$ at $50{ }^{\circ} \mathrm{C}$ gave, after the mixture was refrigerated, crystals suitable for X-ray crystal analysis. Recrystallization from pure heptane afforded the crystals used for the single crystal X-ray structure analysis.

Single-Crystal X-ray Structure Analysis: Crystals of $(5 S, 6 S, 9 R)-\mathbf{4 a}$ were mounted on loops, and all geometric and intensity data were taken from a single crystal. Data collection using Mo- $K_{\alpha}$ radiation $(\lambda=0.71073 \AA)$ was performed at $120 \mathrm{~K}$ with a STOE IPDS II$\mathrm{T}$ diffractometer equipped with an Oxford Cryosystem open flow 
cryostat. ${ }^{[49]}$ The structure was solved and refined using full-matrix least-squares on $F^{2}$ with the SHELX-97 package. ${ }^{[50]}$ All heavy atoms were refined anisotropically. Hydrogen atoms were introduced as fixed contributors, when a residual electronic density was observed near their expected positions. Table 2 shows the crystallographic data and details of the structure analysis.

Table 2. Crystal data and structure refinement for compound $(5 S, 6 S, 9 R)-\mathbf{4 a}$.

\begin{tabular}{ll}
\hline & $(5 S, 6 S, 9 R)-4 a$ \\
\hline Formula & $\mathrm{C}_{12} \mathrm{H}_{22} \mathrm{~N}_{2} \mathrm{O}$ \\
$\mathrm{M}$ [g mol $\left.^{-1}\right]$ & 210.32 \\
Crystal system & trigonal \\
Space group & $P 3_{1} 21$ \\
Unit cell $[\AA]$ & $a=13.3874(5)$ \\
& $c=12.8293(5)$ \\
$V\left[\AA^{3}\right]$ & $1991.25(13)$ \\
$Z$ & 6 \\
$T[\mathrm{~K}]$ & 120 \\
$\rho$ calcd. $\left[\mathrm{Mg} \mathrm{m}^{-3}\right]$ & 1.052 \\
Absorption coefficient & $0.067 \mathrm{~mm}^{-1}$ \\
$F(000)$ & 696 \\
Min. $<\theta<$ max. & $1.76,24.66^{\circ}$ \\
Reflections collected & 4449 \\
Independent reflections & $1274[R(\mathrm{int})=0.0707]$ \\
Data/restraints/parameters & $1274 / 9 / 173$ \\
GOOF & 0.961 \\
$R$ indices $[I>2 \sigma(I)]$ & $R_{1}=0.0535, w R_{2}=0.1085$ \\
$R$ indices (all data) & $R_{1}=0.0803, w R_{2}=0.1192$ \\
\hline
\end{tabular}

CCDC-813985 [for $[(5 S, 6 S, 9 R)-\mathbf{4 a}]$ contains the supplementary crystallographic data for this paper. These data can be obtained free of charge from The Cambridge Crystallographic Data Centre via www.ccdc.cam.ac.uk/data_request/cif.

Isomerization of ( $5 R$ and $5 S)$-(6S,9R)-6-Isopropyl-9-methyl-1,4-diazaspiro[4.5]decan-2-one (4a): Pure $(5 R, 6 S, 9 R)-\mathbf{4 a}$ or $(5 S, 6 S, 9 R)-\mathbf{4 a}$ (approximately $30 \mathrm{mg}$ ) was stirred overnight in ethyl acetate $(1 \mathrm{~mL}$ ) with silica gel $(50 \mathrm{mg})$. The mixture was filtered, and the filtrate was concentrated. NMR spectroscopic analysis in $\mathrm{CDCl}_{3}$ showed that the sample of $(5 R)-\mathbf{4 a}$ isomerized to a mixture containing $25 \%$ of $(5 S)-\mathbf{4 a}$, whereas the sample of pure $(5 S)$-4a remained unchanged. No release of (-)-menthone was observed under these conditions. In a further test, the pure isomers $(20 \mathrm{mg})$ were mixed with flash silica gel $(50 \mathrm{mg})$ and either ethyl acetate or chloroform $\left(\mathrm{CDCl}_{3}, 1 \mathrm{~mL}\right)$, or alternatively, the pure isomers were mixed with TFA (to give a final concentration of $0.1 \%$ ) and either ethyl acetate or chloroform. The mixtures were stirred overnight and filtered (using a $0.45 \mu \mathrm{m}$ membrane filter). The ethyl acetate solutions were concentrated, and the residue was then dissolved in $\mathrm{CDCl}_{3}$, whereas the $\mathrm{CDCl}_{3}$ solutions were directly analyzed by NMR spectroscopy. The compositions indicated in Table 1 were obtained. Equilibration kinetics were measured for solutions of pure $(5 R, 6 S, 9 R)-4 \mathbf{a}$ or $(5 S, 6 S, 9 R)-\mathbf{4 a}(30 \mathrm{mg})$ in $\mathrm{CD}_{3} \mathrm{OD}(0.7 \mathrm{~mL})$ by NMR spectroscopy at different time intervals. To determine the composition of the samples at a given time, we used average peak integrals corresponding to three pairs of ${ }^{13} \mathrm{C}$ NMR signals, that is, the peak pairs at $35.83[(5 S)-4 a]$ and $35.65[(5 R)-4 a]$ ppm, 30.97 [(5R)-4a] and $30.41[(5 S)-4 a] \mathrm{ppm}$, and $19.10[(5 S)-4 \mathrm{a}]$ and 18.17 $[(5 R)-4 a] \mathrm{ppm}$. The data obtained at a given time are listed in Table 3 and illustrated in Figure 5. The sum of the two peak areas of a given pair corresponded to $100 \%$. The standard deviations calculated from the percentages of the three different peak pairs were found to be below 0.009 .
Table 3. Kinetics for the equilibration of imidazolidinones $(5 R, 6 S, 9 R)-\mathbf{4 a}$ and $(5 S, 6 S, 9 R)-\mathbf{4 a}$ in $\mathrm{CD}_{3} \mathrm{OD}$.

\begin{tabular}{|c|c|c|c|c|c|}
\hline $\begin{array}{l}\text { Starting } \\
\text { compd. }\end{array}$ & $4 \mathrm{~h}$ & $18 \mathrm{~h}$ & $42 \mathrm{~h}$ & $66 \mathrm{~h}$ & $90 \mathrm{~h}$ \\
\hline$(5 R, 6 S, 9 R)-\mathbf{4 a}$ & n.d. & $56.6 \%$ & $45.1 \%$ & $41.1 \%$ & $40.1 \%$ \\
\hline$(5 S, 6 S, 9 R)-\mathbf{4 a}$ & $91.0 \%$ & $75.3 \%$ & $67.0 \%$ & $63.0 \%$ & $61.8 \%$ \\
\hline
\end{tabular}

( \pm )-(3S,6S,9R)-6-Isopropyl-3,9-dimethyl-1,4-diazaspiro[4.5]decan-2one (4b): This compound was prepared as described above from (-)-menthone $(1.25 \mathrm{~g}, 8.1 \mathrm{mmol})$, TEA $(0.89 \mathrm{~g}, 8.8 \mathrm{mmol})$, L-alaninamide hydrochloride $(1.00 \mathrm{~g}, 8.0 \mathrm{mmol})$, and dry methanol $(10 \mathrm{~mL})$ to give a yellow oil $(1.02 \mathrm{~g})$. Plug filtration $\left(\mathrm{SiO}_{2}\right.$, ethyl acetate) followed by concentrating the mixture and drying the residue under high vacuum $(0.2 \mathrm{mbar}, 1 \mathrm{~h})$ gave a white solid $(0.54 \mathrm{~g}, 30 \%) .{ }^{1} \mathrm{H}$ NMR (400 MHz, $\mathrm{CDCl}_{3}$, isomer I): $\delta=7.60$ (br. s, $1 \mathrm{H}, \mathrm{NHC}=\mathrm{O}$ ), 3.53 [q, $J=6.9 \mathrm{~Hz}, 1 \mathrm{H}, \mathrm{C}(3) \mathrm{H}], 1.99-1.87$ [m, $1 \mathrm{H}, \mathrm{C}(6) \mathrm{CH}], 1.79-$ $1.65[\mathrm{~m}, 2 \mathrm{H}, \mathrm{C}(8) \mathrm{H}$ and $\mathrm{C}(3) \mathrm{NH}], 1.65-1.56[\mathrm{~m}, 3 \mathrm{H}, \mathrm{C}(7) \mathrm{H}, \mathrm{C}(9)$ $\mathrm{H}$, and $\mathrm{C}(10) \mathrm{H}], 1.44[\mathrm{t}, J=13.3 \mathrm{~Hz}, 1 \mathrm{H}, \mathrm{C}(10)-$ $\mathrm{H}], 1.42-1.35[\mathrm{~m}, 1 \mathrm{H}, \mathrm{C}(7) \mathrm{H}], 1.34\left[\mathrm{~d}, J=7.2 \mathrm{~Hz}, 3 \mathrm{H}, \mathrm{C}(3) \mathrm{CH}_{3}\right]$, $1.21-1.14[\mathrm{~m}, 1 \mathrm{H}, \mathrm{C}(6) \mathrm{H}], 1.01-0.84[\mathrm{~m}, 1 \mathrm{H}, \mathrm{C}(8) \mathrm{H}], 0.91[\mathrm{~d}, J=$ $\left.7.0 \mathrm{~Hz}, \mathrm{C}(6) \mathrm{CHCH}_{3}\right], 0.90$ [d, $\left.J=6.2,3 \mathrm{H}, \mathrm{C}(9) \mathrm{CH}_{3}\right], 0.88$ [d, $J=$ $\left.6.2 \mathrm{~Hz}, 3 \mathrm{H}, \mathrm{C}(6) \mathrm{CHCH}_{3}\right] \mathrm{ppm} .{ }^{13} \mathrm{C}$ NMR $\left(100.6 \mathrm{MHz}, \mathrm{CDCl}_{3}\right.$, isomer I): $\delta=178.42$ [s, $\mathrm{C}(2)=\mathrm{O}], 77.28$ [s, $\mathrm{C}(5)], 55.53$ [d, $\mathrm{C}(3)]$, 52.10 [t, C(10)], 50.91 [d, C(6)], 34.53 [t, C(8)], 29.28 [d, C(9)], 25.10 $[\mathrm{d}, \mathrm{C}(6) \mathrm{CH}], 24.02\left[\mathrm{q}, \mathrm{C}(6) \mathrm{CHCH}_{3}\right], 22.62$ [t, $\left.\mathrm{C}(7)\right], 22.12$ [q, $\mathrm{C}(9) \mathrm{CH}_{3}$ ] 19.64 [q, $\mathrm{C}(3) \mathrm{CH}_{3}$ ], 18.38 [q, $\mathrm{C}(6) \mathrm{CHCH}_{3}$ ] ppm. ${ }^{1} \mathrm{H}$ NMR (400 MHz, $\mathrm{CDCl}_{3}$, isomer II): $\delta=8.26$ (br. s, $1 \mathrm{H}, \mathrm{NHC}=\mathrm{O}$ ), 3.75 [q, $J=6.8 \mathrm{~Hz}, 1 \mathrm{H}, \mathrm{C}(3) \mathrm{H}], 2.23-2.10[\mathrm{~m}, 1 \mathrm{H}, \mathrm{C}(6) \mathrm{CH}], 1.99$ $1.87[\mathrm{~m}, 1 \mathrm{H}, \mathrm{C}(10) \mathrm{H}], 1.87-1.79[\mathrm{~m}, 1 \mathrm{H}, \mathrm{C}(8) \mathrm{H}], 1.79-1.65[\mathrm{~m}, 2$ $\mathrm{H}, \mathrm{C}(7) \mathrm{H}$ and $\mathrm{C}(3) \mathrm{NH}], 1.57-1.48[\mathrm{~m}, 1 \mathrm{H}, \mathrm{C}(9) \mathrm{H}], 1.36-1.25[\mathrm{~m}$, $1 \mathrm{H}, \mathrm{C}(7) \mathrm{H}], 1.32\left[\mathrm{~d}, J=7.2 \mathrm{~Hz}, 3 \mathrm{H}, \mathrm{C}(3) \mathrm{CH}_{3}\right], 1.21-1.14[\mathrm{~m}, 1$ $\mathrm{H}, \mathrm{C}(6) \mathrm{H}], 1.14[\mathrm{t}, J=12.7 \mathrm{~Hz}, 1 \mathrm{H}, \mathrm{C}(10) \mathrm{H}], 1.01-0.84[\mathrm{~m}, 1 \mathrm{H}$, $\mathrm{C}(8) \mathrm{H}], 0.94\left[\mathrm{~d}, J=6.9,3 \mathrm{H}, \mathrm{C}(6) \mathrm{CHCH}_{3}\right], 0.90[\mathrm{~d}, J=6.2,3$ $\left.\mathrm{H}, \mathrm{C}(9) \mathrm{CH}_{3}\right], 0.78\left[\mathrm{~d}, J=6.9 \mathrm{~Hz}, \mathrm{C}(6) \mathrm{CHCH}_{3}\right] \mathrm{ppm} .{ }^{13} \mathrm{C} \mathrm{NMR}$ (100.6 MHz, $\mathrm{CDCl}_{3}$, isomer II): $\delta=177.96$ [s, C(2)=O], 77.16 [s, $\mathrm{C}(5)], 53.30$ [d, C(3)], 50.51 [t, C(10)], 49.10 [d, C(6)], 34.49 [t, $\mathrm{C}(8)$ ], 29.94 [d, C(9)], 24.75 [d, $\mathrm{C}(6) \mathrm{CH}$ ], 23.94 [q, $\mathrm{C}(6) \mathrm{CHCH}_{3}$ ], 22.93 [t, $\mathrm{C}(7)$ ], 22.07 [q, $\mathrm{C}(9) \mathrm{CH}_{3}$ ], 18.02 [q, $\mathrm{C}(3) \mathrm{CH}_{3}$ ], 17.81 [q, $\left.\mathrm{C}(6) \mathrm{CHCH}_{3}\right]$ ppm. IR (neat): $\tilde{v}=3676(\mathrm{w}), 3331(\mathrm{w}), 3162(\mathrm{w})$, 3074 (w), 2947 (m), 2926 (m), 2868 (m), 1697 (s), 1671 (m), 1451 (m), 1439 (w), 1381 (w), 1376 (w), 1362 (m), 1349 (m), 1329 (w), $1308(w), 1294(w), 1277(w), 1266(w), 1241(w), 1206(w), 1180$ (w), $1152(\mathrm{w}), 1129(\mathrm{~m}), 1114(\mathrm{w}), 1058(\mathrm{w}), 1027$ (w), $990(\mathrm{w}), 979$ (w), $953(\mathrm{w}), 932(\mathrm{w}), 905(\mathrm{w}), 870(\mathrm{w}), 858(\mathrm{w}), 803(\mathrm{~m}), 779(\mathrm{~m})$, $738(\mathrm{~m}), 717$ (w), 699 (w), 650 (w), $617(\mathrm{~m}), 607(\mathrm{~m}) \mathrm{cm}^{-1}$. HRMS: calcd. for $\mathrm{C}_{13} \mathrm{H}_{25} \mathrm{~N}_{2} \mathrm{O}[\mathrm{M}+\mathrm{H}]^{+}$225.1967; found 225.1960.

( \pm )-2-Methyl-2-pentylimidazolidin-4-one (5a): This compound was prepared as described above from 2-heptanone (1.03 g, $9.1 \mathrm{mmol})$, TEA $(1.00 \mathrm{~g}, 9.9 \mathrm{mmol}, 1.35 \mathrm{~mL})$, glycinamide hydrochloride $(1.00 \mathrm{~g}, 9.1 \mathrm{mmol})$, and dry methanol $(10 \mathrm{~mL})$. Bulb-to-bulb distillation $\left(0.5 \mathrm{mbar}, 100{ }^{\circ} \mathrm{C}\right)$ to remove the remaining volatile compounds followed by drying under high vacuum yielded a yellow paste $(0.77 \mathrm{~g}, 50 \%) .{ }^{1} \mathrm{H}$ NMR $\left(400 \mathrm{MHz}, \mathrm{CDCl}_{3}\right): \delta=8.11$ (s, 1 $\mathrm{H}, \mathrm{NHC}=\mathrm{O}), 3.49\left[\mathrm{~d}, J=4.9 \mathrm{~Hz}, 2 \mathrm{H}, \mathrm{C}(5) \mathrm{H}_{2}\right], 2.05[\mathrm{~s}, 1 \mathrm{H}, \mathrm{C}(5)-$ $\mathrm{NH}], 1.66-1.57\left[\mathrm{~m}, 2 \mathrm{H}, \mathrm{C}\left(1^{\prime}\right) \mathrm{H}_{2}\right], 1.47-1.22\left[\mathrm{~m}, 6 \mathrm{H}, \mathrm{C}\left(2^{\prime}\right) \mathrm{H}_{2-}\right.$ $\left.\mathrm{C}\left(4^{\prime}\right) \mathrm{H}_{2}\right], 1.39\left[\mathrm{~s}, 3 \mathrm{H}, \mathrm{C}(2) \mathrm{CH}_{3}\right], 0.89[\mathrm{t}, J=6.9 \mathrm{~Hz}, 3 \mathrm{H}$, $\left.\mathrm{C}\left(5^{\prime}\right) \mathrm{H}_{3}\right] \mathrm{ppm} .{ }^{13} \mathrm{C} \mathrm{NMR}\left(100.6 \mathrm{MHz}, \mathrm{CDCl}_{3}\right): \delta=176.94[\mathrm{~s}$, $\mathrm{C}(4)=0], 77.01[\mathrm{~s}, \mathrm{C}(2)], 49.40[\mathrm{t}, \mathrm{C}(5)], 41.89\left[\mathrm{t}, \mathrm{C}\left(1^{\prime}\right)\right], 31.95[\mathrm{t}$, $\mathrm{C}\left(3^{\prime}\right)$ ], 27.07 [q, $\mathrm{C}(2) \mathrm{CH}_{3}$ ], 23.73 [t, $\mathrm{C}\left(2^{\prime}\right)$ ], 22.52 [t, $\left.\mathrm{C}\left(4^{\prime}\right)\right], 13.99$ [q, C(5')] ppm. IR (neat): $\tilde{v}=3199$ (m, br.), 3072 (w), 2955 (m), $2932(\mathrm{~m}), 2859(\mathrm{~m}), 1688(\mathrm{~s}), 1458(\mathrm{~m}), 1416(\mathrm{~m}), 1377$ (m), 1348 (m), 1314 (m), 1240 (w), 1211 (w), 1165 (m), 1143 (m), 1097 (w), 
1076 (w), 1058 (w), 1015 (w), 951 (w), 844 (w), 767 (w), 727 (m) $670(\mathrm{w}), 633(\mathrm{~m}) \mathrm{cm}^{-1}$. HRMS: calcd. for $\mathrm{C}_{9} \mathrm{H}_{19} \mathrm{~N}_{2} \mathrm{O}[\mathrm{M}+\mathrm{H}]^{+}$ 171.1493; found 171.1521 .

( \pm )-(5S)-5-Benzyl-2-methyl-2-pentylimidazolidin-4-one (5c): This compound was prepared as described above from 2-heptanone $(0.51 \mathrm{~g}, 4.5 \mathrm{mmol})$, TEA $(0.50 \mathrm{~g}, 5.0 \mathrm{mmol})$, L-phenylalaninamide hydrochloride $(0.74 \mathrm{~g}, 4.5 \mathrm{mmol})$, and dry methanol $(6 \mathrm{~mL})$ to give a viscous, colorless oil $(0.86 \mathrm{~g}, 73 \%) .{ }^{1} \mathrm{H}$ NMR $\left(400 \mathrm{MHz}, \mathrm{CDCl}_{3}\right)$ : $\delta=7.56$ and $7.55(\mathrm{~s}, 1 \mathrm{H}, \mathrm{NHC}=\mathrm{O}), 7.35-7.20(\mathrm{~m}, 5 \mathrm{H}, \mathrm{Ph}), 3.86$ and $3.84[\mathrm{t}, J=5.4 \mathrm{~Hz}$ and $\mathrm{dd}, J=4.8,1.3 \mathrm{~Hz}, 1 \mathrm{H}, \mathrm{C}(5) \mathrm{H}], 3.12$ $3.00\left[\mathrm{~m}, 2 \mathrm{H}, \mathrm{C}(5) \mathrm{CH}_{2}\right], 1.80$ [br. s, $\left.1 \mathrm{H}, \mathrm{C}(5) \mathrm{NH}\right], 1.62-0.82$ [m, 8 $\left.\mathrm{H}, \mathrm{C}\left(1^{\prime}\right) \mathrm{H}_{2}-\mathrm{C}\left(4^{\prime}\right) \mathrm{H}_{2}\right], 1.33$ and 1.11 [s, $\left.3 \mathrm{H}, \mathrm{C}(2) \mathrm{CH}_{3}\right], 0.87$ and $0.85\left[\mathrm{t}, J=6.9,7.1 \mathrm{~Hz}, 3 \mathrm{H}, \mathrm{C}\left(5^{\prime}\right) \mathrm{H}_{3}\right] \mathrm{ppm} .{ }^{13} \mathrm{C} \mathrm{NMR}(100.6 \mathrm{MHz}$, $\left.\mathrm{CDCl}_{3}\right): \delta=176.97$ and $176.95[\mathrm{~s}, \mathrm{C}(4)=\mathrm{O}], 137.08$ and $137.06[\mathrm{~s}$, $\left.\mathrm{PhC}\left(1^{\prime}\right)\right], 129.70$ and 129.62 [d, $\left.\mathrm{PhC}\left(2^{\prime}\right)\right], 128.66$ and 128.63 [d, $\left.\mathrm{PhC}\left(3^{\prime}\right)\right], 126.89$ and 126.84 [d, $\left.\mathrm{PhC}\left(4^{\prime}\right)\right], 74.62$ and 74.52 [s, C(2)], 60.41 and 59.60 [d, C(5)], 42.80 and 41.62 [t, C(1') ], 37.43 and 36.77 [t, $\mathrm{C}(5) \mathrm{CH}_{2}$ ], 31.95 and 31.80 [t, C(3')], 28.22 and 28.04 [q, $\left.\mathrm{C}(2) \mathrm{CH}_{3}\right], 23.85$ and $22.88\left[\mathrm{t}, \mathrm{C}\left(2^{\prime}\right)\right], 22.56$ and 22.43 [t, $\left.\mathrm{C}\left(4^{\prime}\right)\right]$, 14.00 and 13.95 [q, C ( $\left.\left.5^{\prime}\right)\right]$ ppm. IR (neat): $\tilde{v}=3199$ (m, br.), 3107 (w), 3085 (w), 3063 (w), 3029 (w), 2955 (m), 2930 (m), 2859 (m), 2309 (w), 1947 (w), 1694 (s), 1603 (w), 1583 (w), 1496 (m), 1454 (m), 1435 (m), 1420 (m), 1376 (m), 1341 (m), 1243 (w), 1202 (w), 1180 (w), 1149 (m), 1109 (m), 1078 (w), 1062 (w), 1030 (w), 1002 (w), $973(\mathrm{w}), 935(\mathrm{w}), 917(\mathrm{w}), 749(\mathrm{~m}), 725(\mathrm{~m}), 698(\mathrm{~s}), 664(\mathrm{w})$, $647(\mathrm{w}), 610(\mathrm{~m}) \mathrm{cm}^{-1}$. HRMS: calcd. for $\mathrm{C}_{16} \mathrm{H}_{25} \mathrm{~N}_{2} \mathrm{O}[\mathrm{M}+\mathrm{H}]^{+}$ 261.1961; found 261.1960.

( \pm )-2-Ethyl-2-(2-methylbutyl)imidazolidin-4-one (6a): This compound was prepared as described above from $( \pm)$-5-methyl-3-heptanone $(1.74 \mathrm{~g}, 13.6 \mathrm{mmol})$, TEA $(1.48 \mathrm{~g}, 14.7 \mathrm{mmol}, 2 \mathrm{~mL})$, glycinamide hydrochloride $(1.50 \mathrm{~g}, 13.6 \mathrm{mmol})$, and dry methanol $(15 \mathrm{~mL})$. Bulb-to-bulb distillation to remove the remaining volatile compounds followed by drying under high vacuum yielded a yellow-orange paste $(0.26 \mathrm{~g}, 10 \%) .{ }^{1} \mathrm{H} \mathrm{NMR}\left(400 \mathrm{MHz}, \mathrm{CDCl}_{3}\right): \delta=$ 7.77 and $7.62(\mathrm{~s}, 1 \mathrm{H}, \mathrm{NHC}=\mathrm{O}), 3.49$ and $3.48[\mathrm{~d}, J=1.4,2.0 \mathrm{~Hz}$, $2 \mathrm{H}, \mathrm{C}(5) \mathrm{H}_{2}$ ], 1.97 [br. s, $1 \mathrm{H}, \mathrm{C}(5) \mathrm{NH}$ ] $1.74-1.57[\mathrm{~m}, 3 \mathrm{H}$, $\mathrm{C}(2) \mathrm{CH}_{2} \mathrm{CH}_{3}$ and $\left.\mathrm{C}(2) \mathrm{CH}_{2} \mathrm{CHCH}_{3}\right], 1.56-1.29[\mathrm{~m}, 3 \mathrm{H}, \mathrm{C}(2)-$ $\mathrm{CH}_{2} \mathrm{CHCH}_{3}, \mathrm{CH}\left(\mathrm{CH}_{3}\right) \mathrm{CH}_{2} \mathrm{CH}_{3}$, and $\left.\mathrm{CH}\left(\mathrm{CH}_{3}\right) \mathrm{CH}_{2} \mathrm{CH}_{3}\right], 1.29-$ $1.14\left[\mathrm{~m}, 1 \mathrm{H}, \mathrm{CH}\left(\mathrm{CH}_{3}\right) \mathrm{CH}_{2} \mathrm{CH}_{3}\right], 0.98$ and $0.96(\mathrm{~d}, 3 \mathrm{H}, J=3.2$, $\left.3.8 \mathrm{~Hz}, \mathrm{CHCH}_{3}\right), 0.94\left[\mathrm{t}, J=7.6 \mathrm{~Hz}, 3 \mathrm{H}, \mathrm{C}(2) \mathrm{CH}_{2} \mathrm{CH}_{3}\right], 0.88$ and $0.87\left[\mathrm{t}, J=7.4,7.6 \mathrm{~Hz}, 3 \mathrm{H}, \mathrm{CH}\left(\mathrm{CH}_{3}\right) \mathrm{CH}_{2} \mathrm{CH}_{3}\right.$ ] ppm. ${ }^{13} \mathrm{C} \mathrm{NMR}$ $\left(100.6 \mathrm{MHz}, \mathrm{CDCl}_{3}\right): \delta=176.90$ and $176.86[\mathrm{~s}, \mathrm{C}(4)=\mathrm{O}], 79.80$ and 79.73 [s, C(2)], 49.67 and 49.41 [t, C(5)], 46.04 and 45.87 [t, C(2)$\mathrm{CH}_{2} \mathrm{CHCH}_{3}$ ], 33.41 and 33.19 [t, $\mathrm{C}(2) \mathrm{CH}_{2} \mathrm{CH}_{3}$ ], 31.24 and 30.87 [t, $\left.\mathrm{CH}\left(\mathrm{CH}_{3}\right) \mathrm{CH}_{2} \mathrm{CH}_{3}\right], 30.27$ and $30.13\left(\mathrm{~d}, \mathrm{CHCH}_{3}\right), 21.11$ and 21.05 (q, $\left.\mathrm{CHCH}_{3}\right), 11.35$ and 11.26 [q, $\mathrm{CH}\left(\mathrm{CH}_{3}\right) \mathrm{CH}_{2} \mathrm{CH}_{3}$ ], 7.98 [q, $\left.\mathrm{C}(2) \mathrm{CH}_{2} \mathrm{CH}_{3}\right]$ ppm. IR (neat): $\tilde{v}=3200$ (w, br.), 2962 (m), 2926 (m), 2875 (w), 2856 (w), 1687 (s), 1460 (m), 1423 (m), 1378 (m), $1359(\mathrm{~m}), 1316(\mathrm{~m}), 1161(\mathrm{w}), 1083(\mathrm{w}), 1043$ (w), $969(\mathrm{w}), 909$ (w), 794 (m), 737 (m, br.), $633(\mathrm{~m}) \mathrm{cm}^{-1}$. HRMS: calcd. for $\mathrm{C}_{10} \mathrm{H}_{21} \mathrm{~N}_{2} \mathrm{O}$ $[\mathrm{M}+\mathrm{H}]^{+}$185.1649; found 185.1674 .

( \pm )-2-(Undecan-2-yl)imidazolidin-4-one (7a): This compound was prepared as described above from $( \pm)-2$-methylundecanal $(1.50 \mathrm{~g}$, $8.1 \mathrm{mmol})$, TEA (0.91 g, $9.0 \mathrm{mmol})$, glycinamide hydrochloride $(0.90 \mathrm{~g}, 8.1 \mathrm{mmol})$, and dry methanol $(10 \mathrm{~mL})$ to give a yellow solid $(1.85 \mathrm{~g}, 94 \%) .{ }^{1} \mathrm{H}$ NMR $\left(400 \mathrm{MHz}, \mathrm{CDCl}_{3}\right): \delta=7.85$ and 7.79 (s, $1 \mathrm{H}, \mathrm{NHC}=\mathrm{O}), 4.53-4.45[\mathrm{~m}, 1 \mathrm{H}, \mathrm{C}(2) \mathrm{H}], 3.45\left[\mathrm{~s}, 2 \mathrm{H}, \mathrm{C}(5) \mathrm{H}_{2}\right]$, 2.60 [br. s, $1 \mathrm{H}, \mathrm{C}(5) \mathrm{NH}], 1.66-1.52\left[\mathrm{~m}, 1 \mathrm{H}, \mathrm{C}\left(1^{\prime}\right) \mathrm{H}\right], 1.52-1.05$ $\left[\mathrm{m}, 16 \mathrm{H}, \mathrm{C}\left(2^{\prime}\right)-\mathrm{C}\left(9^{\prime}\right) \mathrm{H}_{2}\right], 0.94$ and $0.93\left[\mathrm{~d}, J=6.7 \mathrm{~Hz}, 3 \mathrm{H}, \mathrm{C}\left(1^{\prime}\right)-\right.$ $\left.\mathrm{HCH}_{3}\right], 0.88\left[\mathrm{t}, J=6.8 \mathrm{~Hz}, 3 \mathrm{H}, \mathrm{C}\left(9^{\prime}\right) \mathrm{CH}_{3}\right] \mathrm{ppm} .{ }^{13} \mathrm{C} \mathrm{NMR}$ $\left(100.6 \mathrm{MHz}, \mathrm{CDCl}_{3}\right): \delta=177.62$ and $177.47[\mathrm{~s}, \mathrm{C}(4)=\mathrm{O}], 76.25$ and 75.94 [d, C(2)], 49.36 and 49.29 [t, C(5)], 39.05 and 38.74 [d, C(1')],
31.90 [t, $\left.\mathrm{C}\left(8^{\prime}\right)\right], 31.77$ and 31.68 [t, $\left.\mathrm{C}\left(2^{\prime}\right)\right], 29.81,29.60$ (2 C), and $29.33\left[\mathrm{t}, \mathrm{C}\left(4^{\prime}\right)-\mathrm{C}\left(7^{\prime}\right)\right], 26.95\left[\mathrm{t}, \mathrm{C}\left(3^{\prime}\right)\right], 22.69\left[\mathrm{t}, \mathrm{C}\left(9^{\prime}\right)\right], 14.20$ and 13.75 [q, $\mathrm{C}\left(1^{\prime}\right) \mathrm{CH}_{3}$ ], 14.11 [t, $\mathrm{C}\left(9^{\prime}\right) \mathrm{CH}_{3}$ ] ppm. IR (neat): $\tilde{\mathrm{v}}=3675$ (w), 3338 (w), 3189 (w, br.), 3079 (w), 2956 (m), 2917 (s), 2852 (s), 1682 (s), 1540 (w), 1456 (m), 1440 (m), 1378 (m), 1357 (w), 1322 (m), $1311(\mathrm{~m}), 1291(\mathrm{w}), 1262(\mathrm{~m}), 1235(\mathrm{w}), 1220(\mathrm{w}), 1208(\mathrm{w})$, $1162(\mathrm{w}), 1139(\mathrm{w}), 1124(\mathrm{w}), 1111(\mathrm{w}), 1091(\mathrm{w}), 1075(\mathrm{w}), 1066$ (w), $1056(w), 1027(w), 1018$ (w), 970 (w), $892(w), 878$ (w), 864 (w), 777 (m, br.), $714(\mathrm{~m}), 659(\mathrm{~m}) \mathrm{cm}^{-1}$. HRMS: calcd. for $\mathrm{C}_{14} \mathrm{H}_{29} \mathrm{~N}_{2} \mathrm{O}[\mathrm{M}+\mathrm{H}]^{+}$241.2273; found 241.2244.

( \pm )-(5S)-5-Methyl-2-(undecan-2-yl)imidazolidin-4-one (7b): This compound was prepared as described above from ( \pm )-2-methylundecanal $(1.48 \mathrm{~g}, 8.0 \mathrm{mmol})$, TEA $(0.89 \mathrm{~g}, 8.8 \mathrm{mmol})$, L-alaninamide hydrochloride $(1.00 \mathrm{~g}, 8.0 \mathrm{mmol})$, and dry methanol $(10 \mathrm{~mL})$. Plug filtration $\left(\mathrm{SiO}_{2}\right.$, ethyl acetate) followed by concentrating the mixture and drying the residue under high vacuum $(0.2 \mathrm{mbar}, 1 \mathrm{~h})$ gave a viscous, colorless oil $(1.52 \mathrm{~g}, 74 \%) .{ }^{1} \mathrm{H}$ NMR $\left(400 \mathrm{MHz}, \mathrm{CDCl}_{3}\right)$ : $\delta=7.78$ and 7.66 (br. s, $1 \mathrm{H}, \mathrm{NHC}=\mathrm{O}$ ), 4.48-4.36 [m, $1 \mathrm{H}, \mathrm{C}(2)$ $\mathrm{H}], 3.59-3.49$ [m, $1 \mathrm{H}, \mathrm{C}(5) \mathrm{H}], 2.33$ [br. s, $1 \mathrm{H}, \mathrm{C}(5) \mathrm{NH}], 1.66-1.52$ $\left[\mathrm{m}, 1 \mathrm{H}, \mathrm{C}\left(1^{\prime}\right) \mathrm{H}\right], 1.52-1.05\left[\mathrm{~m}, 19 \mathrm{H}, \mathrm{C}\left(2^{\prime}\right)-\mathrm{C}\left(9^{\prime}\right) \mathrm{H}_{2}\right.$ and $\left.\mathrm{C}(5) \mathrm{CH}_{3}\right]$, $0.97-0.90\left[\mathrm{~m}, 3 \mathrm{H}, \mathrm{C}\left(1^{\prime}\right) \mathrm{HCH}_{3}\right], 0.87\left[\mathrm{t}, J=6.8 \mathrm{~Hz}, 3 \mathrm{H}, \mathrm{C}\left(9^{\prime}\right)\right.$ $\left.\mathrm{CH}_{3}\right]$ ppm. ${ }^{13} \mathrm{C}$ NMR $\left(100.6 \mathrm{MHz}, \mathrm{CDCl}_{3}\right): \delta=179.70,179.58$, 179.54, and 179.40 [s, C(4)=O], 73.94, 73.89, 73.66, and $73.53[\mathrm{~d}$, $\mathrm{C}(2)], 55.15,55.10,54.56$, and 54.37 [d, C(5)], 39.45, 39.23, 38.37, and 37.99 [d, C(1')], 31.96, 31.86, and $31.74(2 \mathrm{C})$ [t, $\left.\mathrm{C}\left(2^{\prime}\right)\right], 31.90$ [t, $\left.\mathrm{C}\left(8^{\prime}\right)\right], 29.85,29.82,29.80,29.60(2 \mathrm{C}), 29.58$, and 29.33 [t, $\left.\mathrm{C}\left(4^{\prime}\right)-\mathrm{C}\left(7^{\prime}\right)\right], 27.02,26.99,26.93$, and $26.91\left[\mathrm{t}, \mathrm{C}\left(3^{\prime}\right)\right], 22.68[\mathrm{t}$, $\mathrm{C}\left(9^{\prime}\right)$ ], 17.94, 17.82, and $17.36(2 \mathrm{C})$ [q, $\left.\mathrm{C}(5) \mathrm{CH}_{3}\right], 14.39,14.32$, 13.78, and 13.69 [q, $\left.\mathrm{C}\left(1^{\prime}\right) \mathrm{CH}_{3}\right], 14.11$ [t, $\mathrm{C}\left(9^{\prime}\right) \mathrm{CH}_{3}$ ] ppm. IR (neat): $\tilde{v}=3674$ (w), 3198 (w, br.), 3099 (w), 2957 (m), 2922 (s), 2853 (m), 1699 (s), 1456 (m), 1377 (m), 1324 (m), 1295 (m), 1261 (w), 1133 (m), 1058 (m), 996 (w), 944 (w), 776 (w), 721 (m), $686(\mathrm{w}), 617$ (w) $\mathrm{cm}^{-1}$. HRMS: calcd. for $\mathrm{C}_{15} \mathrm{H}_{31} \mathrm{~N}_{2} \mathrm{O}[\mathrm{M}+\mathrm{H}]^{+}$255.2402; found 255.2414

(士)-2-Pentylimidazolidin-4-one (8a): This compound was prepared as described above from hexanal $(1.00 \mathrm{~g}, 10.0 \mathrm{mmol})$, TEA (1.01 g, $10.0 \mathrm{mmol})$, glycinamide hydrochloride $(1.11 \mathrm{~g}, 10.0 \mathrm{mmol})$, and dry methanol $(10 \mathrm{~mL})$ to give a yellow paste $(1.03 \mathrm{~g})$ that slowly crystallized. Column chromatography $\left(\mathrm{SiO}_{2}\right.$, ethyl acetate/methanol, 95:5) followed by concentrating the resulting mixture gave slightly yellow crystals $(0.26 \mathrm{~g}, 16 \%) .{ }^{1} \mathrm{H}$ NMR $\left(400 \mathrm{MHz}, \mathrm{CDCl}_{3}\right)$ : $\delta=7.75(\mathrm{~s}, 1 \mathrm{H}, \mathrm{NHC}=\mathrm{O}), 4.64-4.58[\mathrm{~m}, 1 \mathrm{H}, \mathrm{C}(2) \mathrm{H}], 3.43$ [ddd, $\left.J=16.2,9.5,0.8 \mathrm{~Hz}, 2 \mathrm{H}, \mathrm{C}(5) \mathrm{H}_{2}\right], 2.32-2.23[\mathrm{~m}, 1 \mathrm{H}, \mathrm{C}(5) \mathrm{NH}]$, 1.65-1.56 [m, $\left.2 \mathrm{H}, \mathrm{C}\left(1^{\prime}\right) \mathrm{H}_{2}\right], 1.47-1.24\left[\mathrm{~m}, 6 \mathrm{H}, \mathrm{C}\left(2^{\prime}\right)-\mathrm{C}\left(4^{\prime}\right) \mathrm{H}_{2}\right]$, $0.89\left[\mathrm{t}, J=7.1 \mathrm{~Hz}, 3 \mathrm{H}, \mathrm{C}\left(4^{\prime}\right) \mathrm{CH}_{3}\right] \mathrm{ppm} .{ }^{13} \mathrm{C} \mathrm{NMR}(100.6 \mathrm{MHz}$, $\left.\mathrm{CDCl}_{3}\right): \delta=177.64$ [s, C(4)=O], 72.08 [d, C(2)], 49.22 [t, C(5)], $36.77\left[\mathrm{t}, \mathrm{C}\left(1^{\prime}\right)\right], 31.57\left[\mathrm{t}, \mathrm{C}\left(3^{\prime}\right)\right], 24.36\left[\mathrm{t}, \mathrm{C}\left(2^{\prime}\right)\right], 22.47\left[\mathrm{t}, \mathrm{C}\left(4^{\prime}\right)\right]$, 13.95 [q, $\mathrm{C}\left(4^{\prime}\right) \mathrm{CH}_{3}$ ] ppm. IR (neat): $\tilde{v}=3181$ (m, br.), 3087 (w), 3029 (w), 2962 (w), 2949 (w), 2927 (m), 2911 (w), 2870 (w), 2862 (w), 2847 (w), 2738 (w), 1696 (s), 1492 (w), 1468 (m), 1460 (w), 1437 (m), 1383 (m), 1365 (m), 1351 (m), 1307 (m), 1289 (w), 1275 (m), $1264(\mathrm{~m}), 1249$ (w), $1221(\mathrm{w}), 1198$ (w), 1139 (w), $1127(\mathrm{w})$, 1101 (m), 1076 (m), 1059 (w), 1042 (w), 1011 (m), $982(\mathrm{w}), 952(\mathrm{~m})$, $920(\mathrm{~m}), 896(\mathrm{w}), 880(\mathrm{~m}), 838(\mathrm{w}), 769(\mathrm{~m}), 757(\mathrm{w}), 725(\mathrm{~m}), 696$ (m), $659(\mathrm{~m}), 609$ (w) $\mathrm{cm}^{-1}$. HRMS: calcd. for $\mathrm{C}_{8} \mathrm{H}_{17} \mathrm{~N}_{2} \mathrm{O}$ $[\mathrm{M}+\mathrm{H}]^{+}$157.1335; found 157.1324.

2-(2,4-Dimethylcyclohex-3-en-1-yl)imidazolidin-4-one (9a): This compound was prepared as described above from $( \pm)$-2,4-dimethyl3-cyclohexene-1-carbaldehyde (Triplal ${ }^{\circledR}$, trans/cis, approximately $3: 1 ; 1.00 \mathrm{~g}, 7.2 \mathrm{mmol})$, TEA $(1.10 \mathrm{~g}, 11.0 \mathrm{mmol})$, glycinamide hydrochloride $(0.80 \mathrm{~g}, 7.2 \mathrm{mmol})$, and dry methanol $(10 \mathrm{~mL})$ to give a yellow oil $(1.37 \mathrm{~g})$. Bulb-to-bulb distillation to remove the re- 
maining aldehyde gave a highly viscous, orange-yellow oil [1.10 g, $78 \%,(1 R S, 2 S R)-9 \mathbf{a}$ and $(1 R S, 2 R S)-9 a$ a, trans/cis, approximately 3:1]. ${ }^{1} \mathrm{H}$ NMR (400 MHz, $\mathrm{CDCl}_{3}$, major isomers): $\delta=8.26$ and 7.83 (s, $1 \mathrm{H}, \mathrm{NHC}=\mathrm{O}), 5.26-5.18\left[\mathrm{~m}, 1 \mathrm{H}, \mathrm{C}\left(3^{\prime}\right) \mathrm{H}\right], 4.80$ and 4.74 [d, $J=4.6,5.4 \mathrm{~Hz}, 1 \mathrm{H}, \mathrm{C}(2) \mathrm{H}], 3.51-3.37\left[\mathrm{~m}, 2 \mathrm{H}, \mathrm{C}(5) \mathrm{H}_{2}\right], 2.27-$ $2.09\left[\mathrm{~m}, 1 \mathrm{H}, \mathrm{C}\left(2^{\prime}\right) \mathrm{H}\right], 2.22$ [br. s, $\left.1 \mathrm{H}, \mathrm{C}(5) \mathrm{NH}\right], 2.07-1.88[\mathrm{~m}, 2$ $\left.\mathrm{H}, \mathrm{C}\left(5^{\prime}\right) \mathrm{H}_{2}\right], 1.85-1.72\left[\mathrm{~m}, 1 \mathrm{H}, \mathrm{C}\left(6^{\prime}\right) \mathrm{H}\right], 1.64\left[\mathrm{~s}, 3 \mathrm{H}, \mathrm{C}\left(4^{\prime}\right) \mathrm{CH}_{3}\right]$, 1.57-1.43 [m, $\left.1 \mathrm{H}, \mathrm{C}\left(6^{\prime}\right) \mathrm{H}\right], 1.43-1.32\left[\mathrm{~m}, 1 \mathrm{H}, \mathrm{C}\left(1^{\prime}\right) \mathrm{H}\right], 1.04$ and $1.02\left[\mathrm{~d}, J=7.0,6.9 \mathrm{~Hz}, 3 \mathrm{H}, \mathrm{C}\left(2^{\prime}\right) \mathrm{CH}_{3}\right] \mathrm{ppm} .{ }^{13} \mathrm{C} \mathrm{NMR}$ (100.6 MHz, $\mathrm{CDCl}_{3}$, major isomers): $\delta=177.90$ and $177.74[\mathrm{~s}$, $\mathrm{C}(4)=\mathrm{O}], 133.24$ and 133.21 [s, C(4')], 126.67 and 126.47 [d, C(3')], 72.91 and 72.40 [d, C(2)], 49.46 and 49.29 [t, C(5)], 45.48 [d, C(1')], 31.16 [d, $\left.\mathrm{C}\left(2^{\prime}\right)\right], 28.55$ and 28.21 [t, $\left.\mathrm{C}\left(5^{\prime}\right)\right], 23.48$ and 23.44 [q, $\left.\mathrm{C}\left(4^{\prime}\right) \mathrm{CH}_{3}\right], 21.03$ and 20.76 [q, $\left.\mathrm{C}\left(2^{\prime}\right) \mathrm{CH}_{3}\right], 20.66$ and 20.17 [t, $\left.\mathrm{C}\left(6^{\prime}\right)\right] \mathrm{ppm} .{ }^{1} \mathrm{H}$ NMR (400 MHz, $\mathrm{CDCl}_{3}$, minor isomers): $\delta=8.28$ and $8.21(\mathrm{~s}, 1 \mathrm{H}, \mathrm{NHC}=\mathrm{O}), 5.40-5.32\left[\mathrm{~m}, 1 \mathrm{H}, \mathrm{C}\left(3^{\prime}\right) \mathrm{H}\right], 4.46$ and $4.44[\mathrm{~d}, J=5.9,6.2 \mathrm{~Hz}, 1 \mathrm{H}, \mathrm{C}(2) \mathrm{H}], 3.51-3.37\left[\mathrm{~m}, 2 \mathrm{H}, \mathrm{C}(5) \mathrm{H}_{2}\right]$, 2.45-2.28 [m, $\left.1 \mathrm{H}, \mathrm{C}\left(2^{\prime}\right) \mathrm{H}\right], 2.22$ [br. s, $1 \mathrm{H}, \mathrm{C}(5) \mathrm{NH}$ ], 2.07-1.88 $\left[\mathrm{m}, 2 \mathrm{H}, \mathrm{C}\left(5^{\prime}\right) \mathrm{H}_{2}\right], 1.85-1.72\left[\mathrm{~m}, 1 \mathrm{H}, \mathrm{C}\left(6^{\prime}\right) \mathrm{H}\right], 1.66$ and $1.64[\mathrm{~s}, 3$ $\left.\mathrm{H}, \mathrm{C}\left(4^{\prime}\right) \mathrm{CH}_{3}\right], 1.65-1.58\left[\mathrm{~m}, 1.5 \mathrm{H}, \mathrm{C}\left(1^{\prime}\right) \mathrm{H}\right.$ and $\left.\mathrm{C}\left(6^{\prime}\right) \mathrm{H}\right], 1.43-1.32$ $\left[\mathrm{m}, 0.5 \mathrm{H}, \mathrm{C}\left(6^{\prime}\right) \mathrm{H}\right], 0.93$ and $0.93[\mathrm{~d}, J=7.0,6.9 \mathrm{~Hz}, 3 \mathrm{H}$, $\left.\mathrm{C}\left(2^{\prime}\right) \mathrm{CH}_{3}\right] \mathrm{ppm} .{ }^{13} \mathrm{C} \mathrm{NMR}\left(100.6 \mathrm{MHz}, \mathrm{CDCl}_{3}\right.$, minor isomers): $\delta$ $=178.10$ and $177.95[\mathrm{~s}, \mathrm{C}(4)=\mathrm{O}], 133.09$ and $133.02\left[\mathrm{~s}, \mathrm{C}\left(4^{\prime}\right)\right]$, 126.70 and 126.63 [d, C( $\left.3^{\prime}\right)$ ], 74.13 and 74.00 [d, C(2)], 49.10 and 49.08 [t, C(5)], 44.17 and 43.80 [d, C(1')], 30.22 and 30.21 [t, C(5 $\left.5^{\prime}\right)$ ], 30.12 and $30.01\left[\mathrm{~d}, \mathrm{C}\left(2^{\prime}\right)\right], 23.40$ and 23.39 [q, $\mathrm{C}\left(4^{\prime}\right) \mathrm{CH}_{3}$ ], 20.02 and 19.14 [t, $\left.\mathrm{C}\left(6^{\prime}\right)\right], 15.43$ and 15.35 [q, $\left.\mathrm{C}\left(2^{\prime}\right) \mathrm{CH}_{3}\right] \mathrm{ppm}$. IR (neat): $\tilde{v}=3196$ (m, br.), 3093 (w), 3004 (w), 2957 (m), $2924(\mathrm{~m}), 2911$ (m), $2870(\mathrm{~m}), 2834(\mathrm{w}), 2730(\mathrm{w}), 1693(\mathrm{~s}), 1580(\mathrm{w}), 1506(\mathrm{w})$, 1435 (m), 1373 (m), 1357 (w), 1310 (m), 1270 (m), 1251 (m), 1197 (w), 1161 (w), 1143 (w), $1119(\mathrm{~m}), 1088$ (w), 1039 (m), 1001 (m), 966 (m), $933(\mathrm{w}), 906(\mathrm{w}), 841(\mathrm{~m}), 799(\mathrm{~m}), 762(\mathrm{w}), 746(\mathrm{w}), 725$ (m), $682(\mathrm{~m}), 648(\mathrm{~m}), 607(\mathrm{w}) \mathrm{cm}^{-1}$. HRMS: calcd. for $\mathrm{C}_{11} \mathrm{H}_{19} \mathrm{~N}_{2} \mathrm{O}$ $[\mathrm{M}+\mathrm{H}]^{+}$195.1492; found 195.1439.

2-(2,4,4-Trimethylpentyl)oxazolidin-4-one (10): Boron trifluoride etherate $(3.8 \mathrm{~mL})$ was added to a mixture of 2-hydroxyacetamide $(1.00 \mathrm{~g}, 13.3 \mathrm{mmol})$ and $( \pm)-3,5,5$-trimethylhexanal $(1.87 \mathrm{~g}$, $13.2 \mathrm{mmol})$ in THF $(5 \mathrm{~mL})$ and ether $(7.5 \mathrm{~mL})$. After stirring at room temperature for $24 \mathrm{~h}$, the reaction mixture was washed with sodium acetate $(10 \%, 5 \mathrm{~mL})$, dried with $\mathrm{Na}_{2} \mathrm{SO}_{4}$, and concentrated to give a brownish-orange paste $(2.86 \mathrm{~g})$. Column chromatography $\left(\mathrm{SiO}_{2}\right.$, ethyl acetate/heptane, $\left.4: 1\right)$ gave a yellow oil $(0.28 \mathrm{~g} .11 \%$, approximate ratio of diastereomers, $2: 1) .{ }^{1} \mathrm{H}$ NMR $(400 \mathrm{MHz}$, $\mathrm{CDCl}_{3}$, major isomer): $\delta=8.29$ (br. s, $1 \mathrm{H}, \mathrm{NHC}=\mathrm{O}$ ), 5.33-5.27 $[\mathrm{m}, 1 \mathrm{H}, \mathrm{C}(2) \mathrm{H}], 4.27-4.14\left[\mathrm{~m}, 2 \mathrm{H}, \mathrm{C}(5) \mathrm{H}_{2}\right], 1.83-1.42[\mathrm{~m}, 3 \mathrm{H}$, $\mathrm{C}\left(1^{\prime}\right) \mathrm{H}_{2}$ and $\left.\mathrm{C}\left(2^{\prime}\right) \mathrm{H}\right], 1.29-1.20\left[\mathrm{~m}, 1 \mathrm{H}, \mathrm{C}\left(3^{\prime}\right) \mathrm{H}\right], 1.16-1.05[\mathrm{~m}, 1$ $\left.\mathrm{H}, \mathrm{C}\left(3^{\prime}\right) \mathrm{H}\right], 0.98\left[\mathrm{~d}, J=6.7 \mathrm{~Hz}, 3 \mathrm{H}, \mathrm{C}\left(2^{\prime}\right) \mathrm{CH}_{3}\right], 0.90[\mathrm{~s}, 9 \mathrm{H}$, $\left.\mathrm{C}\left(4^{\prime}\right) \mathrm{CH}_{3}\right] \mathrm{ppm} .{ }^{13} \mathrm{C}$ NMR (100.6 MHz, $\mathrm{CDCl}_{3}$, major isomer): $\delta$ $=174.28[\mathrm{~s}, \mathrm{C}(4)=\mathrm{O}], 87.66[\mathrm{~d}, \mathrm{C}(2)], 67.14[\mathrm{t}, \mathrm{C}(5)], 51.46\left[\mathrm{t}, \mathrm{C}\left(3^{\prime}\right)\right]$, $45.86\left[\mathrm{t}, \mathrm{C}\left(1^{\prime}\right)\right.$ ], 31.17 [s, $\mathrm{C}\left(4^{\prime}\right)$ ], 29.93 [q, $\mathrm{C}\left(4^{\prime}\right) \mathrm{CH}_{3}$ ], 24.99 [d, $\mathrm{C}\left(2^{\prime}\right)$ ], 22.57 [q, $\mathrm{C}\left(2^{\prime}\right) \mathrm{CH}_{3}$ ] ppm. ${ }^{1} \mathrm{H}$ NMR $\left(400 \mathrm{MHz}, \mathrm{CDCl}_{3}\right.$, minor isomer): $\delta=8.50$ (br. s, $1 \mathrm{H}, \mathrm{NHC}=\mathrm{O}$ ), 5.33-5.27 [m, $1 \mathrm{H}$, $\mathrm{C}(2) \mathrm{H}], 4.27-4.14\left[\mathrm{~m}, 2 \mathrm{H}, \mathrm{C}(5) \mathrm{H}_{2}\right], 1.83-1.42\left[\mathrm{~m}, 3 \mathrm{H}, \mathrm{C}\left(1^{\prime}\right) \mathrm{H}_{2}\right.$ and $\left.\mathrm{C}\left(2^{\prime}\right) \mathrm{H}\right], 1.29-1.20\left[\mathrm{~m}, 1 \mathrm{H}, \mathrm{C}\left(3^{\prime}\right) \mathrm{H}\right], 1.16-1.05[\mathrm{~m}, 1 \mathrm{H}$, $\left.\mathrm{C}\left(3^{\prime}\right) \mathrm{H}\right], 0.99\left[\mathrm{~d}, J=6.4 \mathrm{~Hz}, 3 \mathrm{H}, \mathrm{C}\left(2^{\prime}\right) \mathrm{CH}_{3}\right], 0.90[\mathrm{~s}, 9 \mathrm{H}$, $\left.\mathrm{C}\left(4^{\prime}\right) \mathrm{CH}_{3}\right] \mathrm{ppm} .{ }^{13} \mathrm{C}$ NMR (100.6 MHz, $\mathrm{CDCl}_{3}$, minor isomer): $\delta$ $=174.38[\mathrm{~s}, \mathrm{C}(4)=\mathrm{O}], 87.87[\mathrm{~d}, \mathrm{C}(2)], 67.18[\mathrm{t}, \mathrm{C}(5)], 51.31\left[\mathrm{t}, \mathrm{C}\left(3^{\prime}\right)\right]$, 45.84 [t, $\mathrm{C}\left(1^{\prime}\right)$ ], 31.13 [s, C(4')], 29.93 [q, $\mathrm{C}\left(4^{\prime}\right) \mathrm{CH}_{3}$ ], 25.26 [d, $\left.\mathrm{C}\left(2^{\prime}\right)\right], 22.99$ [q, $\mathrm{C}\left(2^{\prime}\right) \mathrm{CH}_{3}$ ] ppm. IR (neat): $\tilde{v}=3206$ (m, br.), 3106 (w), $2952(\mathrm{~m}), 2903(\mathrm{~m}), 2867(\mathrm{~m}), 1712$ (s), $1529(\mathrm{w}), 1476(\mathrm{w})$, 1465 (w), 1439 (m, br.), 1394 (m), 1378 (w), 1364 (m), 1330 (m), 1279 (m), 1247 (w), 1201 (w), 1139 (w), 1087 (m), 1036 (w), 993 (w), 974 (w), 941 (w), 929 (w), 821 (m), 750 (m), 722 (m, br.), 655 (m), $608(w) \mathrm{cm}^{-1}$. HRMS: calcd. for $\mathrm{C}_{11} \mathrm{H}_{22} \mathrm{NO}_{2}[\mathrm{M}+\mathrm{H}]^{+}$ 200.1645; found 200.1613 .

3-Methyl-2-(2,4,4-trimethylpentyl)oxazolidine (11): ( \pm )-3,5,5-Trimethylhexanal $(1.89 \mathrm{~g}, 13.1 \mathrm{mmol})$ in toluene $(2.5 \mathrm{~mL})$ was added to an ice-cold solution of 2-(methylamino)ethanol (1.01 g, 13 . $5 \mathrm{mmol})$ in toluene $(17.5 \mathrm{~mL})$. The mixture was heated to reflux for $4 \mathrm{~h}$ along with the azeotropic removal of water. The reaction mixture was then cooled to room temperature and concentrated under vacuum to give the crude compound (2.02 g). Bulb-to-bulb distillation $\left(50^{\circ} \mathrm{C}, 0.2 \mathrm{mbar}\right)$ yielded a colorless oil $(1.33 \mathrm{~g}, 49 \%$, approximate ratio of diastereomers, 1.2:1). ${ }^{1} \mathrm{H}$ NMR $(400 \mathrm{MHz}$, $\mathrm{CDCl}_{3}$, major isomer): $\delta=3.92-3.80\left[\mathrm{~m}, 3 \mathrm{H}, \mathrm{C}(2) \mathrm{H}\right.$ and $\left.\mathrm{C}(5) \mathrm{H}_{2}\right]$, 3.24-3.15 [m, $1 \mathrm{H}, \mathrm{C}(4) \mathrm{H}], 2.66-2.57[\mathrm{~m}, 1 \mathrm{H}, \mathrm{C}(4) \mathrm{H}], 2.35[\mathrm{~s}, 3 \mathrm{H}$, $\left.\mathrm{NCH}_{3}\right], 1.81-1.72\left[\mathrm{~m}, 1 \mathrm{H}, \mathrm{C}\left(2^{\prime}\right) \mathrm{H}\right], 1.59-1.45\left[\mathrm{~m}, 1 \mathrm{H}, \mathrm{C}\left(1^{\prime}\right) \mathrm{H}\right]$, $1.42-1.30\left[\mathrm{~m}, 1 \mathrm{H}, \mathrm{C}\left(1^{\prime}\right) \mathrm{H}\right], 1.24[\mathrm{dd}, J=13.9,4.3 \mathrm{~Hz}, 1 \mathrm{H}$, $\left.\mathrm{C}\left(3^{\prime}\right) \mathrm{H}\right], 1.10\left[\mathrm{dd}, J=14.0,5.9 \mathrm{~Hz}, 1 \mathrm{H}, \mathrm{C}\left(3^{\prime}\right) \mathrm{H}\right], 0.97[\mathrm{~d}, J=$ $\left.6.7 \mathrm{~Hz}, 3 \mathrm{H}, \mathrm{C}\left(2^{\prime}\right) \mathrm{CH}_{3}\right], 0.91\left[\mathrm{~s}, 9 \mathrm{H}, \mathrm{C}\left(4^{\prime}\right) \mathrm{CH}_{3}\right] \mathrm{ppm} .{ }^{13} \mathrm{C} \mathrm{NMR}$ (100.6 $\mathrm{MHz}, \mathrm{CDCl}_{3}$, major isomer): $\delta=95.80[\mathrm{~d}, \mathrm{C}(2)], 63.85[\mathrm{t}$, $\mathrm{C}(5)], 54.53$ [t, C(4)], 51.91 [t, C(3')], 42.94 [t, C(1')], 39.04 (q, $\left.\mathrm{NCH}_{3}\right), 31.20$ [s, $\mathrm{C}\left(4^{\prime}\right)$ ], 30.00 [q, $\mathrm{C}\left(4^{\prime}\right) \mathrm{CH}_{3}$ ], 26.05 [d, $\mathrm{C}\left(2^{\prime}\right)$ ], 22.36 [q, $\mathrm{C}\left(2^{\prime}\right) \mathrm{CH}_{3}$ ] ppm. ${ }^{1} \mathrm{H}$ NMR (400 $\mathrm{MHz}, \mathrm{CDCl}_{3}$, minor isomer): $\delta$ $=3.92-3.80\left[\mathrm{~m}, 3 \mathrm{H}, \mathrm{C}(2) \mathrm{H}\right.$ and $\left.\mathrm{C}(5) \mathrm{H}_{2}\right], 3.24-3.15[\mathrm{~m}, 1 \mathrm{H}$, $\mathrm{C}(4) \mathrm{H}], 2.66-2.57$ [m, $1 \mathrm{H}, \mathrm{C}(4) \mathrm{H}], 2.35$ [s, $\left.3 \mathrm{H}, \mathrm{NCH}_{3}\right], 1.72-1.64$ $\left[\mathrm{m}, 1 \mathrm{H}, \mathrm{C}\left(2^{\prime}\right) \mathrm{H}\right], 1.59-1.45\left[\mathrm{~m}, 1 \mathrm{H}, \mathrm{C}\left(1^{\prime}\right) \mathrm{H}\right], 1.42-1.30[\mathrm{~m}, 2 \mathrm{H}$, $\mathrm{C}\left(1^{\prime}\right) \mathrm{H}$ ] 1.27 [dd, $J=14.1,3.2 \mathrm{~Hz}, 1 \mathrm{H}, \mathrm{C}\left(3^{\prime}\right) \mathrm{H}$ ], 1.06 [dd, $J=$ $\left.13.8,6.8 \mathrm{~Hz}, 1 \mathrm{H}, \mathrm{C}\left(3^{\prime}\right) \mathrm{H}\right], 1.00\left[\mathrm{~d}, J=6.7 \mathrm{~Hz}, 3 \mathrm{H}, \mathrm{C}\left(2^{\prime}\right) \mathrm{CH}_{3}\right]$, $0.91\left[\mathrm{~s}, 9 \mathrm{H}, \mathrm{C}\left(4^{\prime}\right) \mathrm{CH}_{3}\right] \mathrm{ppm} .{ }^{13} \mathrm{C} \mathrm{NMR}\left(100.6 \mathrm{MHz}, \mathrm{CDCl}_{3}\right.$, minor isomer): $\delta=96.20[\mathrm{~d}, \mathrm{C}(2)], 63.73[\mathrm{t}, \mathrm{C}(5)], 54.53$ [t, C(4)], $51.06[\mathrm{t}$, $\left.\mathrm{C}\left(3^{\prime}\right)\right], 42.75$ [t, $\left.\mathrm{C}\left(1^{\prime}\right)\right], 38.85\left(\mathrm{q}, \mathrm{NCH}_{3}\right), 31.06$ [s, $\left.\mathrm{C}\left(4^{\prime}\right)\right], 30.00$ [q, $\mathrm{C}\left(4^{\prime}\right) \mathrm{CH}_{3}$ ], 26.42 [d, $\mathrm{C}\left(2^{\prime}\right)$ ], 23.70 [q, $\mathrm{C}\left(2^{\prime}\right) \mathrm{CH}_{3}$ ] ppm. IR (neat): $\tilde{v}$ $=2950(\mathrm{~s}), 2892(\mathrm{~m}), 2868(\mathrm{~m}), 2847(\mathrm{w}), 2799(\mathrm{~m}), 2702(\mathrm{w}), 2659$ (w), $2594(\mathrm{w}), 1683(\mathrm{w}), 1651$ (w), 1467 (m), $1456(\mathrm{~m}), 1421(\mathrm{w})$, 1392 (m), 1376 (m), 1364 (s), 1293 (w), 1247 (m), 1207 (m), 1161 (m), $1143(\mathrm{~m}), 1116(\mathrm{~m}), 1087(\mathrm{~s}), 1024(\mathrm{~s}), 953(\mathrm{~m}), 920(\mathrm{~m}), 863$ (w), $852(w), 809(w), 780(w), 743(w), 703(w), 673(w), 665(w)$, 647 (w), 639 (w), 620 (w) $\mathrm{cm}^{-1}$. HRMS: calcd. for $\mathrm{C}_{12} \mathrm{H}_{26} \mathrm{NO}$ [M $+\mathrm{H}]^{+}$200.2009; found 200.2003.

Procedure for the Hydrolysis in Aqueous Media (with Increasing Headspace Volume): Buffer stock solutions were prepared by dissolving (upon sonication) eight buffer tablets (Fluka), $\mathrm{pH}=4.0$ (potassium hydrogen phthalate) or 7.0 (sodium/potassium phosphate), in demineralized water $(640 \mathrm{~mL})$. Then, acetonitrile $(160 \mathrm{~mL})$ was added to give a mixture of water/acetonitrile (4:1, $\mathrm{v} / \mathrm{v})$. The $\mathrm{pH}$ values of the final buffer solutions were measured (with a Mettler Toledo MP220 apparatus with an InLab 410 Ag/ $\mathrm{AgCl}$ glass electrode) as 4.6 (for the potassium hydrogen phthalate buffer solution) and 7.3 (for the sodium/potassium phosphate buffer solution). A concentrated cationic surfactant formulation of a TEA-esterquat (Stepantex VL 90A, 16.5\%, w/w), 10\% calcium chloride $(0.6 \%, \mathrm{w} / \mathrm{w})$, and water $(82.9 \%, \mathrm{w} / \mathrm{w})$ was prepared. This formulation $(1.8 \mathrm{~g})$ was then dispersed with demineralized, cold tap water $(600 \mathrm{~mL})$ to give a diluted TEA-esterquat emulsion, and the $\mathrm{pH}$ was measured as 4.4. Imidazolidinones $\mathbf{1 - 9}$ and oxazolidine $\mathbf{1 1}$ were weighted into ethanol $(2 \mathrm{~mL})$ to obtain concentrations as closely as possible to $7.5 \times 10^{-2} \mathrm{~mol} \mathrm{~L}^{-1}(\mathbf{1 a}, 31.4 \mathrm{mg} ; \mathbf{1 b}, 33.1 \mathrm{mg}$; 1c, 44.7 mg; 1d, $37.2 \mathrm{mg}$; 2a, $29.9 \mathrm{mg} ; \mathbf{2 b}, 32.1 \mathrm{mg} ; \mathbf{2 c}, 43.8 \mathrm{mg}$; $\mathbf{2 d}$, $36.6 \mathrm{mg} ; \mathbf{3 a}, 31.6 \mathrm{mg} ; \mathbf{3 b}, 34.0 \mathrm{mg} ; \mathbf{4 a}, 32.0 \mathrm{mg} ; \mathbf{4 b}, 33.7 \mathrm{mg} ; \mathbf{5 a}$, $25.6 \mathrm{mg}$; 6a, $28.2 \mathrm{mg} ; 7 \mathbf{a}, 36.6 \mathrm{mg} ; 7 \mathbf{b}, 38.4 \mathrm{mg} ; \mathbf{8 a}, 23.5 \mathrm{mg} ; 9 \mathbf{9}$, $29.9 \mathrm{mg} ; \mathbf{1 1}, 32.5 \mathrm{mg}$ ). All measurements were carried out in duplicate. In a $50-\mathrm{mL}$ glass flask, the imidazolidinone or oxazolidine solution $(0.1 \mathrm{~mL})$ was added to either one of the buffer solutions or the cationic surfactant emulsion $(50 \mathrm{~mL}$, to give a final concentration of approximately $1.5 \times 10^{-4} \mathrm{~mol} \mathrm{~L}^{-1}$ ). The flask was closed 
and shaken vigorously $(10 \times)$. After $1 \mathrm{~h}$, the flask was shaken again $(10 \times)$, and then an aliquot $(5 \mathrm{~mL})$ was removed by pipette and extracted with heptane $(0.3 \mathrm{~mL})$. The heptane phase $(0.10$ to $0.15 \mathrm{~mL})$ was decanted and analyzed by GC. The samples $(5 \mu \mathrm{L})$ were injected into an Agilent Technologies 7890A GC system equipped with a HP-5 capillary column $(30 \mathrm{~m}, 0.32 \mathrm{~mm}$ ID, film $0.25 \mu \mathrm{m})$ and eluted with a constant flow of $\mathrm{He}\left(3 \mathrm{~mL} \mathrm{~min}^{-1}\right)$ using a temperature gradient starting from $60^{\circ} \mathrm{C}$ during $1 \mathrm{~min}$, then heating to $260{ }^{\circ} \mathrm{C}$ at $20^{\circ} \mathrm{Cmin}^{-1}$. The injector temperature was kept at $250{ }^{\circ} \mathrm{C}$ with the FID-detector temperature at $280^{\circ} \mathrm{C}$. The samples were left at room temperature $\left(21.7^{\circ} \mathrm{C} \pm 1.7^{\circ} \mathrm{C}\right)$. Additional aliquots $(5 \mathrm{~mL})$ were removed by pipette and extracted after 24,48 , $72,96,168,192,216$, and $240 \mathrm{~h}$. During the measurement, the total volume of the sample in the flask continuously decreased, as the headspace above it increased. The amount of aldehydes and ketones released from the precursors was quantified by external standard calibration using a mixture of the freshly distilled carbonyl compounds at five different concentrations. Calibrations were carried out in triplicate by linear regression (forced through the origin of the coordinate system).

Verification of the Extraction Efficiency: A stock solution of $( \pm)$ 3,5,5-trimethylhexanal $(215.1 \mathrm{mg})$ in ethanol $(20 \mathrm{~mL})$ was prepared. The solution was then diluted by a factor of 2 and 10, and each of these solutions was further diluted by a factor of 10 to give solutions at five different concentrations $(1,5,10,50$, and 100 mol$\%$ of the total amount of aldehyde to be theoretically released from the respective precursor). The different solutions $(0.14 \mathrm{~mL})$ were then added to the buffer solutions or the cationic surfactant emulsion $(7 \mathrm{~mL})$ in a small glass flask. Two flasks were prepared for each solution or emulsion. The flasks were closed and shaken vigorously $(10 \times)$. After $1 \mathrm{~h}$, the content of one of the flasks was extracted with heptane $(0.3 \mathrm{~mL})$. The heptane phase $(0.10$ to $0.15 \mathrm{~mL}$ ) was decanted and analyzed by GC as described above. The content of the second flask was extracted after $240 \mathrm{~h}$. All measurements were carried out in triplicate. The average amount of aldehyde extracted was plotted against the total amount originally added to the sample. Similarly, the efficiency of the extraction for the other fragrances was determined using concentrations corresponding to $1\left[( \pm)\right.$-2-methylundecanal], 3 (Trifernal ${ }^{\circledR}$, hexanal, and Triplal $\left.{ }^{\circledR}\right), 10[(R)$-citronellal], 15 (2-heptanone), 20 [(-)-menthone], and $35 \mathrm{~mol}-\%$ [ $( \pm)-5$-methyl-3-heptanone] with respect to the total amount to be released from the corresponding precursor. Extractions with heptane were carried out $1 \mathrm{~h}$ after the preparation of the samples. In all cases, average values were obtained from three measurements (see Supporting Information).

Procedure for the Dynamic Headspace Measurements on Cotton: ${ }^{[10,48]}$ For the measurements, a solution of imidazolidinone $\left(1 \mathrm{~mL}\right.$, conc. $\left.=7.5 \times 10^{-2} \mathrm{~mol} \mathrm{~L}^{-1}\right)$ was added to a concentrated TEA-esterquat fabric softener formulation $(1.80 \mathrm{~g}$, see above) Similarly, a reference sample containing an equimolar amount of the carbonyl compound to be released was prepared. Each sample was then dispersed in a beaker with demineralized, cold tap water $(600 \mathrm{~mL})$ to give the diluted TEA-esterquat solution (see above). One cotton sheet [EMPA (Eidgenössische Materialprüfanstalt) cotton test cloth $\mathrm{Nr}$. 221, prewashed with an unperfumed detergent powder and cut to approximately $12 \times 12 \mathrm{~cm}$ sheets] was added to each beaker with the diluted surfactant emulsion. The sheets were stirred manually ( $3 \mathrm{~min}$ ), set aside ( $2 \mathrm{~min}$ ), and then wrung out by hand and weighed to ensure a constant quantity of residual water. The two sheets were line dried for $3 \mathrm{~d}$. Each sheet was then put inside a headspace sampling cell (about $160 \mathrm{~mL}$ inner volume) which was thermostatted at $25^{\circ} \mathrm{C}$ and exposed to a constant airflow (about $200 \mathrm{~mL} \mathrm{~min}^{-1}$ ). The air was filtered through activated charcoal and aspirated through a saturated solution of $\mathrm{NaCl}$. The headspace system was allowed to equilibrate $(15 \mathrm{~min})$, and then the volatiles were adsorbed onto a clean Tenax ${ }^{\circledR}$ cartridge $(15 \mathrm{~min})$ and a waste Tenax $^{\circledR}$ cartridge $(45 \mathrm{~min})$, the latter of which was discarded. The sampling was repeated $(7 \times)$. The cartridges were desorbed with a Perkin-Elmer TurboMatrix ATD 350 desorber coupled to a Perkin-Elmer Autosystem XL gas chromatograph equipped with a J\&W Scientific DB1 capillary column $(30 \mathrm{~m}$, $0.25 \mathrm{~mm}$ ID, film $0.25 \mu \mathrm{m}$ ) and a Perkin-Elmer Turbomass Upgrade mass spectrometer. The volatiles were analyzed by $\mathrm{GC}$ using a two-step temperature gradient starting from $60^{\circ} \mathrm{C}$ during $5 \mathrm{~min}$, then heating to $120^{\circ} \mathrm{C}$ at $15^{\circ} \mathrm{Cmin}^{-1}$, and then heating to $230^{\circ} \mathrm{C}$ at $45^{\circ} \mathrm{Cmin}^{-1}$. The injection temperature was $240^{\circ} \mathrm{C}$ with the detector temperature at $260^{\circ} \mathrm{C}$. Headspace concentrations (in $\mathrm{ng} \mathrm{L}^{-1}$ of air) were obtained by an external standard calibration of the corresponding fragrant aldehydes and ketones using ethanol solutions at a minimum of five different concentrations. The calibrated solutions $(0.2 \mu \mathrm{L})$ were injected onto Tenax ${ }^{\circledR}$ cartridges, which were then immediately desorbed under the same conditions as those resulting from the headspace sampling. Calibrations were carried out by linear regression (forced through the origin of the coordinate system).

Note: Trifernal ${ }^{\circledR}$ is a registered trademark of Firmenich SA, Tri$\mathrm{plal}^{\mathbb{B}}$ is a registered trademark of Int. Flavors and Fragrances Inc.

Supporting Information (see footnote on the first page of this article): Instrumentation used in this work, additional figures of the crystal structure, the hydrolysis experiments and the headspace measurements, the calculated $\log P_{\mathrm{o} / \mathrm{w}}$ values of the precursors, the data for the efficiency of the aldehyde and ketone extractions, the procedure for the hydrolysis experiments in aqueous media with a constant headspace volume, the numerical data for Figures 7, 8, 9, and 10 , and the figures of the ${ }^{1} \mathrm{H}$ and ${ }^{13} \mathrm{C}$ NMR spectra for compounds 1-11.

\section{Acknowledgments}

We thank Sandy Frank and Dr. Wolfgang Fieber for the NMR measurements, Daniel Grenno for recording the high resolution mass spectra, Sophie Cottier for her assistance in the synthesis and headspace sampling, and Dr. Alexandre Huboux and Dr. Maurus Marty for the fruitful discussions.

[1] For example, see: a) S. Schulz (Ed.), Topics in Current Chemistry, vol. 239 and 240: The Chemistry of Pheromones and Other Semiochemicals, Springer Verlag, Berlin, 2004 and 2005; b) E. Breitmaier, Terpenes - Flavors, Fragrances, Pharmaca, Pheromones, Wiley-VCH, Weinheim, 2006; c) R. G. Berger (Ed.), Flavours and Fragrances - Chemistry, Bioprocessing and Sustainability, Springer Verlag, Berlin, 2007; d) G. Ohloff, W. Pickenhagen, P. Kraft, Scent and Chemistry, Wiley-VCH, Weinheim, 2011.

[2] a) A. Herrmann, Angew. Chem. 2007, 119, 5938-5967; Angew. Chem. Int. Ed. 2007, 46, 5836-5863; b) A. Herrmann, in: The Chemistry and Biology of Volatiles (Ed.: A. Herrmann), John Wiley \& Sons, Chichester, 2010, pp. 333-362.

[3] a) A. Herrmann, Photochem. Photobiol. Sci. 2012, 11, 446-459; b) A. Herrmann, Org. Biomol. Chem. 2009, 7, 3195-3204; c) S. Derrer, F. Flachsmann, C. Plessis, M. Stang, Chimia 2007, 61, 665-669; d) V. Rataj, F. Ruyffelaere, J.-M. Aubry, Cah. Formulation 2005, 12, 82-96; e) R. J. Perry, in: Delivery System Handbook for Personal Care and Cosmetic Products: Technology, Applications, and Formulations (Ed.: M. R. Rosen), William Andrew Publishing, Norwich, 2005, pp. 667-682; f) A. Herrmann, Spectrum (Bowling Green) 2004, 17(2), 10-13, and 19. 
[4] For example, see: a) H. Kamogawa, Y. Haramoto, T. Nakazawa, H. Sugiura, M. Nanasawa, Bull. Chem. Soc. Jpn. 1981, 54, 1577-1578; b) T. Gerke (Henkel KGaA), DE 19718537, 1998 [Chem. Abstr. 1998, 129, 347183]; c) S. Yolles (D. E. Brook), US Patent 3857964, 1974 [Chem. Abstr. 1975, 82, 154067]; d) W. Grab (Givaudan SA), WO 2008011742, 2008 [Chem. Abstr. 2008, 148, 213860]; e) H. Morinaga, H. Morikawa, Y. Wang, A. Sudo, T. Endo, Macromolecules 2009, 42, 2229-2235; f) Y. Wang, H. Morinaga, A. Sudo, T. Endo, J. Polym. Sci., Part A: Polym. Chem. 2010, 48, 3816-3822.

[5] a) D. A. Anderson, P. A. Christenson, P. J. Riker, J. M. Yurecko Jr, (Givaudan \& Cie SA), WO 92/10107, 1992 [Chem. Abstr. 1992, 117, 211294]; b) M. Gautschi (Givaudan Roure SA), WO 00/04009, 2000 [Chem. Abstr. 2000, 132, 107176].

[6] K. D. Perring, A. Birkbeck, K. M. Tuck (Quest International B. V.), WO 00/38616, 2000 [Chem. Abstr. 2000, 133, 79036].

[7] G. B. Womack, R. C. Vermeer, H. T. Kalinoski (Firmenich SA), WO 03/082850, 2003 [Chem. Abstr. 2003, 139, 311993].

[8] a) T. Leidig (Haarmann \& Reimer GmbH), DE 1133847, 1962 [Chem. Abstr. 1962, 57, 12650e]; b) G. S. Miracle, K. N. Price (The Procter \& Gamble Company), WO 00/24721, 2000 [Chem. Abstr. 2000, 132, 325854]; c) R. R. Dykstra, G. S. Miracle, L. M. Gray (The Procter \& Gamble Company), WO 02/38120, 2002 [Chem. Abstr. 2002, 136, 390775]; d) U. Huchel, T. Gerke, S. Sauf (Henkel KGaA), DE 102006003092,2007 [Chem. Abstr. 2007, 147, 211892]; e) Y. Wang, H. Morinaga, A. Sudo, T. Endo, U. Huchel, T. Huver (Henkel KGaA), WO 2010/ 094356, 2010 [Chem. Abstr. 2010, 153, 367504]; f) Y. Wang, H. Morinaga, A. Sudo, T. Endo, J. Polym. Sci., Part A: Polym. Chem. 2011, 49, 1881-1886.

[9] a) U. Huchel, S. Sauf, T. Gerke (Henkel KGaA), DE 102005 062175, 2007 [Chem. Abstr. 2007, 147, 101295]; b) H. Morinaga, H. Morikawa, A. Sudo, T. Endo, J. Polym. Sci., Part A: Polym. Chem. 2010, 48, 4529-4536.

[10] a) G. Godin, B. Levrand, A. Trachsel, J.-M. Lehn, A. Herrmann, Chem. Commun. 2010, 46, 3125-3127; b) B. Buchs, G. Godin, A. Trachsel, J.-Y. de Saint Laumer, J.-M. Lehn, A. Herrmann, Eur. J. Org. Chem. 2011, 681-695.

[11] a) T. H. Fife, L. Hagopian, J. Am. Chem. Soc. 1968, 90, 10071014; b) T. H. Fife, J. E. C. Hutchins, J. Org. Chem. 1980, 45, 2099-2104; c) K. Pihlaja, A. Parkkinen, H. Lönnberg, J. Chem. Soc. Perkin Trans. 2 1983, 1223-1226; d) A. Buur, H. Bundgaard, Int. J. Pharm. 1984, 18, 325-334.

[12] a) J. Hine, K. W. Narducy, J. Am. Chem. Soc. 1973, 95, 33623368; b) C. Chapuis, A. Gauvreau, A. Klaebe, A. Lattes, J. J. Peire, Bull. Soc. Chim. Fr. 1973, 977-985; c) G. P. Tuszynski, R. G. Kallen, J. Am. Chem. Soc. 1975, 97, 2860-2875; d) P. S. Tobias, R. G. Kallen, J. Am. Chem. Soc. 1975, 97, 6530-6539; e) T. H. Fife, A. M. Pellino, J. Am. Chem. Soc. 1980, 102, 30623071.

[13] a) S. Blank, D. Seebach, Angew. Chem. 1993, 105, 1780-1781; Angew. Chem. Int. Ed. Engl. 1993, 32, 1765-1766; b) A. Studer, T. Hintermann, D. Seebach, Helv. Chim. Acta 1995, 78, 11851206; c) M. Hoffmann, S. Blank, D. Seebach, E. Küsters, E. Schmid, Chirality 1998, 10, 217-222.

[14] a) I. Solodin, Monatsh. Chem. 1992, 123, 565-570; b) C. Hubert, B. Garrigues, Can. J. Chem. 1998, 76, 234-237.

[15] a) A. Khalaj, R. D. Bazaz, M. Shekarchi, Monatsh. Chem. 1997, 128, 395-398; b) M. A. Nooshabadi, K. Aghapoor, M. Bolourtchian, M. M. Heravi, J. Chem. Res., Synop. 1999, 498499; c) S. A. Selkälä, A. M. P. Koskinen, Eur. J. Org. Chem. 2005, 1620-1624.

[16] Z. Xu, T. Buechler, K. Wheeler, H. Wang, Chem. Eur. J. 2010, 16, 2972-2976.

[17] a) J. C. Burley, R. Gilmour, T. J. Prior, G. M. Day, Acta Crystallogr., Sect. C: Cryst. Struct. Commun. 2008, 64, o10-o14; b) I. Panov, P. Drabina, Z. Padělková, J. Hanusek, M. Sedlák, J. Heterocycl. Chem. 2010, 47, 1356-1360.

[18] G. Verado, P. Geatti, P. Martinuzzi, M. Merli, N. Toniutti, Eur. J. Org. Chem. 2003, 3840-3849.
[19] I. V. Vystorop, N. P. Konovalova, Y. V. Nelyubina, V. N. Varfolomeev, B. S. Fedorov, T. E. Sashenkova, E. N. Berseneva, K. A. Lyssenko, R. G. Kostyanovsky, Russ. Chem. Bull. 2010, 59, $127-135$.

[20] a) X. Huang, J. Huang, Y. Wen, X. Feng, Adv. Synth. Catal. 2006, 348, 2579-2584; b) J.-C. Rossi, M. Marull, L. Boiteau, J. Taillades, Eur. J. Org. Chem. 2007, 662-668.

[21] C. A. Panetta, M. Pesh-Imam, J. Org. Chem. 1972, 37, 302304.

[22] F. Cardinaux, M. Brenner, Helv. Chim. Acta 1973, 56, 339-347.

[23] a) M. Pinza, C. Farina, A. Cerri, U. Pfeiffer, M. T. Riccaboni, S. Banfi, R. Biagetti, O. Pozzi, M. Magnani, L. Dorigotti, J. Med. Chem. 1993, 36, 4214-4220; b) A. Pernet-Poil-Chevrier, F. Cantagrel, K. Le Jeune, C. Philouze, P. Y. Chavant, Tetrahedron: Asymmetry 2006, 17, 1969-1974; c) J. Liu, G. Cui, M. Zhao, C. Cui, J. Ju, S. Peng, Bioorg. Med. Chem. 2007, 15, 7773-7788; d) H. Wang, L. Peng, M. Zhao, J. Liu, X. Zhang, Y. Wang, J. Wu, L. Li, S. Peng, Bioorg. Med. Chem. 2011, 19, 871-882.

[24] S. Cheng, H. Wu, X. Xu, Synth. Commun. 2007, 37, 297-308.

[25] a) P. Gomes, M. J. Araújo, M. Rodrigues, N. Vale, Z. Azevedo, J. Iley, P. Chambel, J. Morais, R. Moreira, Tetrahedron 2004, 60, 5551-5562; b) P. Chambel, R. Capela, F. Lopes, J. Iley, J. Morais, L. Gouveia, J. R. B. Gomes, P. Gomes, R. Moreira, Tetrahedron 2006, 62, 9883-9891; c) N. Vale, F. Nogueira, V. E. do Rosário, P. Gomes, R. Moreira, Eur. J. Med. Chem. 2009, 44, 2506-2516.

[26] G. Giorgioni, F. Claudi, S. Ruggieri, M. Ricciutelli, G. F. Palmieri, A. Di Stefano, P. Sozio, L. S. Cerasa, A. Chiavaroli, C. Ferrante, G. Orlando, R. A. Glennon, Bioorg. Med. Chem. 2010, 18, 1834-1843.

[27] a) G. J. Rasmussen, H. Bundgaard, Int. J. Pharm. 1991, 71, 45 53; b) G. J. Rasmussen, H. Bundgaard, Int. J. Pharm. 1991, 76, 113-122; c) S. W. Larsen, M. Sidenius, M. Ankersen, C. Larsen, Eur. J. Pharm. Sci. 2003, 20, 233-240.

[28] A. Bak, M. Fich, B. D. Larsen, S. Frokjaer, G. J. Friis, Eur. J. Pharm. Sci. 1999, 7, 317-323.

[29] a) G. A. Hardcastle Jr, D. A. Johnson, C. A. Panetta, A. I. Scott, S. A. Sutherland, J. Org. Chem. 1966, 31, 897-899; b) A. K. Durbin, H. N. Rydon, J. Chem. Soc. C 1970, 1249-1250; c) A. Tsuji, T. Yamana, Chem. Pharm. Bull. 1974, 22, 2434 2443; d) U. Klixbüll, H. Bundgaard, Int. J. Pharm. 1984, 20, 273-284; e) U. Klixbüll, H. Bundgaard, Int. J. Pharm. 1985, 23, $163-173$.

[30] U. Zehavi, D. Ben-Ishai, J. Org. Chem. 1961, 26, 1097-1101.

[31] P. M. Hardy, D. J. Samworth, J. Chem. Soc. Perkin Trans. 1 1977, 1954-1960.

[32] a) J. Pospíšil, M. Potáček, Heterocycles 2004, 63, 1165-1173; b) F. Miklós, F. Fülöp, Eur. J. Org. Chem. 2010, 959-965.

[33] K. H. Nam, C.-H. Oh, J. K. Cho, H. J. Kim, K.-S. Lee, J.-H. Cho, Arch. Pharm. (Weinheim) 1996, 329, 443-446.

[34] T. Połoński, Tetrahedron 1985, 41, 611-616.

[35] a) D. Yamashiro, V. du Vigneaud, J. Am. Chem. Soc. 1968, 90 , 487-490; b) V. J. Hruby, D. Yamashiro, V. du Vigneaud, J. Am. Chem. Soc. 1968, 90, 7106-7110.

[36] A. L. Fuentes de Arriba, L. Simón, C. Raposo, V. Alcázar, F. Sanz, F. M. Muñiz, J. R. Morán, Org. Biomol. Chem. 2010, 8, 2979-2985.

[37] Y. Ariyoshi, N. Sato, Bull. Chem. Soc. Jpn. 1972, 45, 20152018.

[38] Parts of this publication are the subject of a patent application, see: A. Herrmann, G. Godin (Firmenich SA), WO 2008/ 142591, 2008 [Chem. Abstr. 2008, 149, 576555].

[39] W. O. Moss, A. C. Jones, R. Wisedale, M. F. Mahon, K. C. Molloy, R. H. Bradbury, N. J. Hales, T. Gallagher, J. Chem. Soc. Perkin Trans. 1 1992, 2615-2624.

[40] For example, see: a) R. E. Bowman, A. Campbell, E. M. Tanner, J. Chem. Soc. 1963, 692-694; b) D. C. Bishop, R. E. Bowman, A. Campbell, W. A. Jones, J. Chem. Soc. 1963, 2381- 
2385; c) W. R. Roush, A. P. Essenfeld, J. S. Warmus, B. B. Brown, Tetrahedron Lett. 1989, 30, 7305-7308.

[41] K. Pilgram, G. E. Pollard, J. Heterocycl. Chem. 1977, 14, 1029 1033.

[42] a) M. I. Levinson, J. Surfactants Deterg. 1999, 2, 223-235; b) F. E. Friedli, H. J. Koehle, M. Fender, M. Watts, R. Keys, P. Frank, C. J. Toney, M. Doerr, J. Surfactants Deterg. 2002, 5 , 211-216; c) S. Mishra, V. K. Tyagi, J. Oleo Sci. 2007, 56, 269276.

[43] a) S. D. Escher, E. Oliveros, J. Am. Oil Chem. Soc. 1994, 71, 31-40; b) T. Stora, S. Escher, A. Morris, Chimia 2001, 55, 406412; c) S. K. Obendorf, H. Liu, K. Tan, M. J. Leonard, T. J. Young, M. J. Incorvia, J. Surfactants Deterg. 2009, 12, 43-58.

[44] a) A. Leo, C. Hansch, D. Elkins, Chem. Rev. 1971, 71, 525616; b) A. J. Leo, Chem. Rev. 1993, 93, 1281-1306.

[45] Vapor pressures and $\log P_{\mathrm{o} / \mathrm{w}}$ were calculated with the EPI Suite PBT Calculator 1.0.0 based on the EPIwin program, US Environmental Protection Agency, 2000.

[46] For example, see: a) D. Berthier, A. Trachsel, C. Fehr, L. Ouali, A. Herrmann, Helv. Chim. Acta 2005, 88, 3089-3108; b) A.
Trachsel, J.-Y. de Saint Laumer, O. P. Haefliger, A. Herrmann, Chem. Eur. J. 2009, 15, 2846-2860; c) D. L. Berthier, N. Paret, A. Trachsel, A. Herrmann, Bioconjugate Chem. 2010, 21, 2000 2012.

[47] For an example, see: R. L. Rouseff, K. R. Cadwallader (Eds.), Headspace Analysis of Foods and Flavors: Theory and Practice, Kluwer Academic/Plenum Publishers, New York, 2001.

[48] a) B. Levrand, W. Fieber, J.-M. Lehn, A. Herrmann, Helv. Chim. Acta 2007, 90, 2281-2314; b) B. Buchs, W. Fieber, D. Drahoňovský, J.-M. Lehn, A. Herrmann, Chem. Biodiversity, 2012, in press, DOI: $10.1002 / c b d v .201100383$.

[49] J. Cosier, A. M. Glazer, J. Appl. Crystallogr. 1986, 19, 105-107. [50] a) M. C. Burla, R. Caliandro, M. Camalli, B. Carrozzini, G. L. Cascarano, L. De Caro, C. Giacovazzo, G. Polidori, R. Spagna, J. Appl. Crystallogr. 2005, 38, 381-388; b) G. M. Sheldrick, SHELX-97, Program for crystal structure refinement, University of Göttingen, Germany, 1997. 